\begin{tabular}{|c|c|c|c|c|c|c|c|}
\hline \multicolumn{3}{|c|}{$\begin{array}{l}\text { 2. To: (Receiving Organization) } \\
\text { Distribution }\end{array}$} & $\begin{array}{l}\text { 3. From: (Originating Organization) } \\
\text { Tank Farm Restoration and Safe } \\
\text { Operation }\end{array}$ & \multicolumn{4}{|c|}{$\begin{array}{l}\text { 4. Related EDT No.: } \\
\text { N/A }\end{array}$} \\
\hline \multicolumn{2}{|c|}{ 5. Proj./Prog./Dept./Div.: } & \multicolumn{2}{|c|}{$\begin{array}{l}\text { 6. Design Authority/ Design } \\
\text { Agent/Cog. } \\
\text { Engr.: } \\
\text { J. S. Hammers }\end{array}$} & \multicolumn{4}{|c|}{ 7. Purchase Order No.: } \\
\hline \multirow{2}{*}{\multicolumn{4}{|c|}{$\begin{array}{l}\text { 8. Oxiginator Remarks: } \\
\text { This EDT releases Acceptance Test Report Document HNF-465 } 847 \text {. } \\
\text { for Project } W-314 \text {. }\end{array}$}} & \multicolumn{4}{|c|}{$\begin{array}{l}\text { 9. Equip./Component No.: } \\
\text { N/A }\end{array}$} \\
\hline & & & & \multicolumn{4}{|c|}{$\begin{array}{c}\text { 10. System/Bldg./Facility: } \\
200 \mathrm{E} / \mathrm{ANB}\end{array}$} \\
\hline \multirow{3}{*}{\multicolumn{4}{|c|}{ 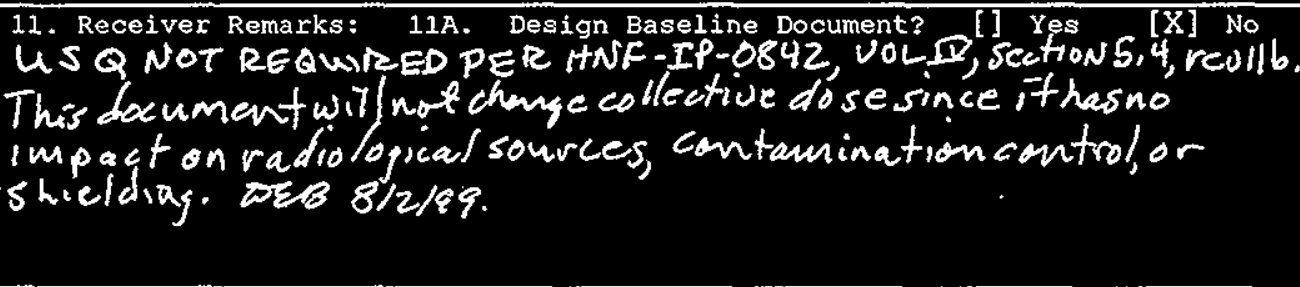 }} & \multicolumn{4}{|c|}{$\begin{array}{c}\text { 12. Major Assm. Dwg. No.: } \\
\text { N/A }\end{array}$} \\
\hline & & & & \multicolumn{4}{|c|}{$\begin{array}{l}\text { 13. Permit/Permit Application } \\
\text { No.: } \\
\text { N/A }\end{array}$} \\
\hline & & & & \multicolumn{4}{|c|}{$\begin{array}{l}\text { 14. Required Response Date: } \\
\text { N/A }\end{array}$} \\
\hline \multicolumn{4}{|c|}{ DATA TRANSMITTED } & (E) & (G) & (H) & (I) \\
\hline $\begin{array}{l}\text { (A) } \\
\text { Item } \\
\text { Ho. }\end{array}$ & (B) Documente/Drawing No. & \begin{tabular}{|l|l} 
(C) & (D) \\
Sheet & Rev. \\
No. & No.
\end{tabular} & 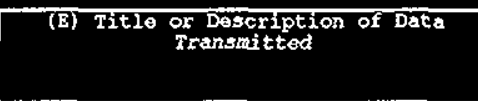 & $\begin{array}{l}\text { Approval } \\
\text { Desig- } \\
\text { nator }\end{array}$ & $\begin{array}{l}\text { Reason } \\
\text { for } \\
\text { Trans- } \\
\text { mittal }\end{array}$ & $\begin{array}{l}\text { Origi- } \\
\text { nator } \\
\text { Dispo- } \\
\text { sition }\end{array}$ & $\begin{array}{l}\text { Raceiv- } \\
\text { er } \\
\text { Dispo- } \\
\text { sition }\end{array}$ \\
\hline 1 & 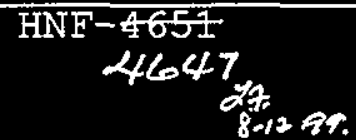 & $\overline{0}$ & $\begin{array}{l}\text { ATR HNE-4647 for HNF-4646 } \\
\text { 241-ANA-B Leak Detection } \\
\text { ANB-WT-LDSTA-231 for } \\
\text { Project W-314 }\end{array}$ & $E S Q$ & 1 & 1 & 1 \\
\hline
\end{tabular}

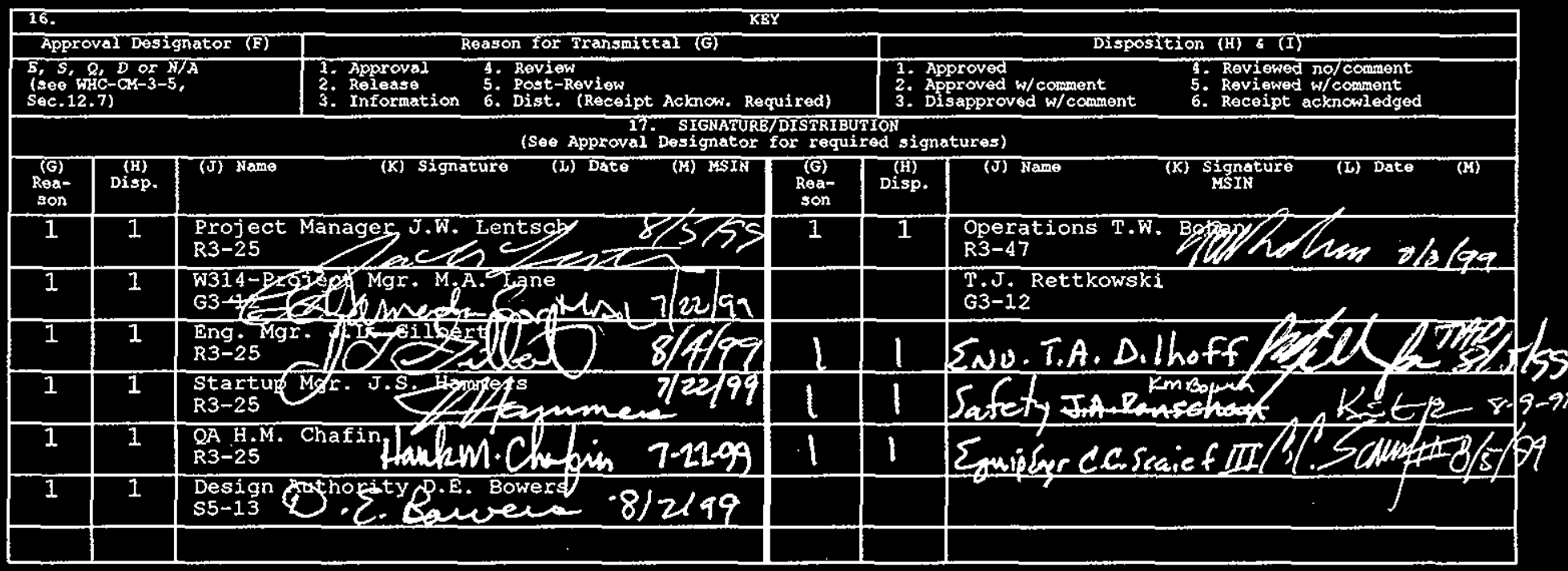

\begin{tabular}{|c|c|c|c|}
\hline Pffemanara $8 / 3 / 99$ & $\underbrace{}_{\substack{\text { Authorized Representative } \\
\text { for Receiving Organization }}}$ & 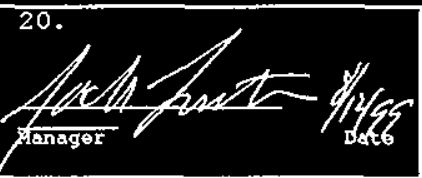 & $\begin{array}{l}\text { 21. DOE APPROVAL (if required) } \\
\text { Ctrl. No. } \\
\text { [] Approved } \\
\text { [] Approved w/ comments } \\
\text { [] Disapproved w/comments }\end{array}$ \\
\hline
\end{tabular}

BD -7400-172-2 (05/96) GEF097 


\section{Project W-314 Acceptance Test Report HNF-4647 for HNF-4646 241-B Pit Leak Detection ANB-WT- LDSTA-231 for Project W-314}

Jack S. Hammers

Numatec Hanford Company, Richland, WA 99352

U.S. Department of Energy Contract DE-AC06-96RL13200

EDT/ECN: 627001 UC: 2030

Org Code: 8c610 Charge Code: 106051

B\&R Code: EW3130010 Total Pages: 9694 ดit. $8 \%$ \% $\%$

Key Words: Acceptance Test Report, Project W-314, HNF-4647, 241-AN-B Pit Leak Detection, ANB-WT-LDSTA-231

TRADEMARK DISCLAIMER. Reference herein to any specific commercial product, process, or service by trade name, trademark, manufacturer, or otherwise, does not necessarily constitute or imply its endorsement, recommendation, or favoring by the United States Government or any agency thereof or its contractors or subcontractors.

Printed in the United States of America. To obtain copies of this document, contact: Document Control Services, P.0. Box 950, Mailstop H6-08, Richland WA 99352, Phone (509) 372-2420; Fax (509) 376-4989.

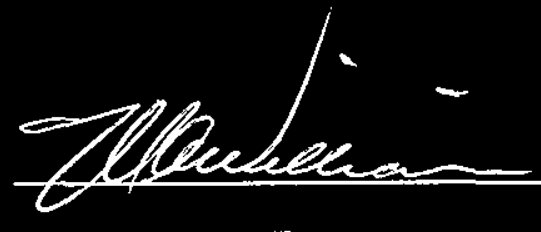

Release Approval

Release Stamp

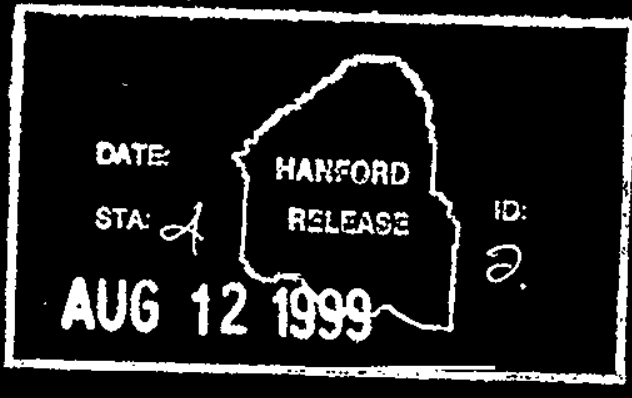

Date 


\section{Acceptance Test Report \\ HNF - 4647- Rewo \\ For \\ HNF - 4646 \\ 241- AN-B Pit Leak Detection \\ ANA - WT - LDSTA - 231}

\section{Project W-314}

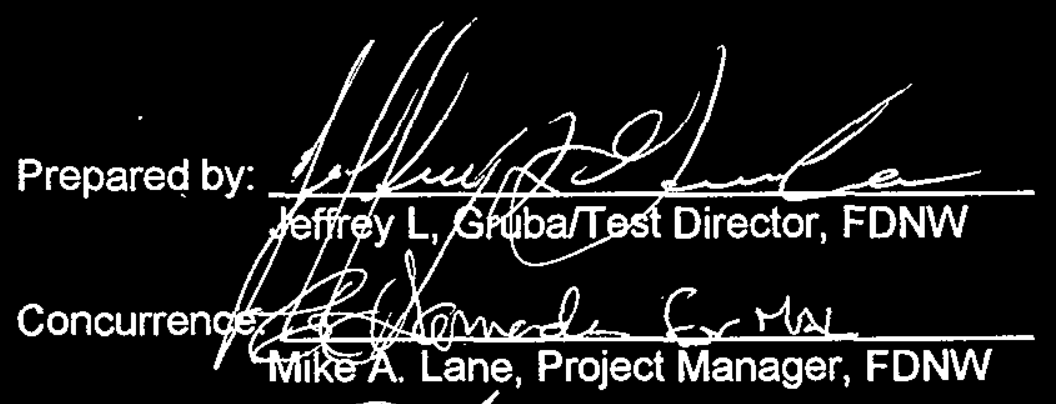

Concurrence:

concurrence: LauleM.Chubin Henry M. Chafin, QALLead, FDNW

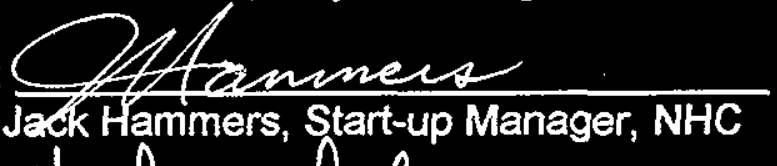

Concurrence: $\frac{\text { Tim W. Bohan, Operations, LMHC }}{\text { TMC }}$

concurrence: 2. . B. Buvero

David E. Bowers, Design Authority, LMHC

Concurrence:

conlewe un

Ed F. Enloe J., Authorized Inspector, FDH

Concurrence:

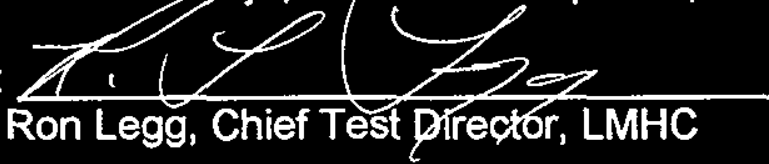

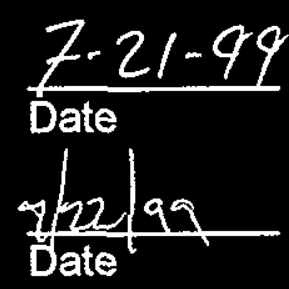

$\frac{7 / 21 / 99}{\text { Date }}$ $7-22-99$

Date

$\frac{8 / 4 / 99}{\text { Date }}$

$\frac{8 / 2 / 99}{\text { Date }}$

$\frac{8 / 4 / 99}{\text { Date }}$

$\frac{8-11-99}{\text { Date }}$ 


\section{CONTENTS}

1.0 INTRODUCTION............................................................................................... 1

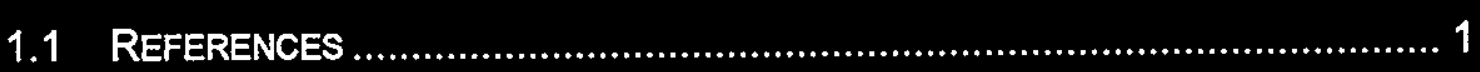

2.0 DESCRIPTION OF TEST........................................................................ 1

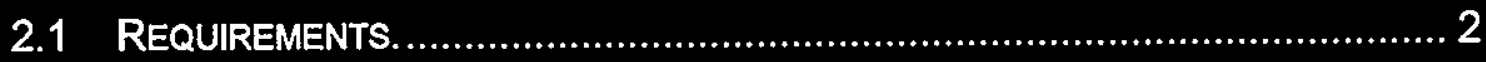

3.0 TEST RESULTS .............................................................................. 6

4.0 CONCLUSIONS AND RECOMMENDATIONS........................................... 4

Appendix A (attached field copy of Acceptance Test Procedure) 


\subsection{Introduction}

The purpose of the test was to verify that the AN Tank Farm B Pit Leak Detector components are functionally integrated and operate in accordance with engineering design specifications.

The Acceptance Test Procedure HNF-4646, 241-AN-B-Pit Leak Detection ANB-WTLDSTA-231 was conducted between 26 June and 02 July 1999 at the 200E AN Tank Farm. The test has been completed with no open test exceptions.

The test was conducted prior to final engineering "as built" activities being completed this had no impact on the procedure or test results. All components, identified in the procedure were found to be labeled and identified as written in the procedure.

\subsection{References}

HNF-1902, Rev. 4 "Specific Test and Evaluation Plan" (STEP)

HMF-SD-W314-PDS-003, Rev. 1 "Project Development Specification for Pit Leak Detection" (PDS)

\subsection{Description of test}

The scope of the system tested by this procedure is limited to the leak detector elements, the local control and indication panel, its power source and the interface terminal connections for some of the remote control and indication functions that are to be installed in the future.

The test required or performed the following:

Circuit breaker identification and 120Vac-line voltage verification for the power feed to the leak detection relay panel.

MTL Trip Amplifier to be adjusted to trip at $1.5 \mathrm{Vdc}$ probe voltage.

Local hand switches to be repositioned and circuit operation verified to be in accordance with design requirements.

Leak detector probe height to be set above the pit floor.

Test Switches were installed to demonstrate supervisory circuitry functions as well as the interface for future control and indication circuits. 
Leak detection function was demonstrated by addition of salt water to the valve pit until alarm actuation was achieved. The drain valve was operated and alarm reset was verified.

\subsection{Requirements}

Requirements are extracted from HNF-SD-W314-PDS-003 as defined in STEP HNF- 1902.

2.1.1 PDS Requirement 3.2.1.1.3 - "Pit leak detection system sensors shall be positioned no higher than one inch above the floor's in the lowest part of the pit or in a sump in the pit."

2.1.2 PDS Requirement 3.2.1.1.6 -"The required response time of the pit leak detection system sensor and control panel shall be electrically supervised"

2.1.3 PDS Requirement 3.2.1.2.1 - "Loss of power to the leak detection probes, shall provide an output signal to the local alarm and MPS." (Master Pump Shutdown)

2.1.3 PDS Requirement 3.2.1.2.2- "A detected failure in the leak detection system shall provide an output signal to the local alarm and MPS."

2.1.4 PDS Requirement 3.2.1.2.3 - "The leak detection system shall perform an operational test of itself when commanded by the MPS. The test shall include alarm, circuitry, and sensor functions of the leak detection system."

2.1.5 PDS Requirement 3.2.1.3.1 - "The local alarm shall be a warning light. The light shall identify the pit where the leak or malfunction occurred. Each warning light location shall be determined from Human Factors Analysis."

2.1.6 PDS Requirement 3.2.1.3.2 - "The reset/acknowledgement of the local alarm shall be either from an MPS system Human-Machine Interface (HMI) location or the local leak detection relay panel."

2.1.7 PDS Requirement 3.2.1.3.3 - " The local alarm shall operate as follows:

, Immediately upon detecting a leak or malfunction, the local alarm shall flash and produce an audible alarm. 
- After the local alarm is acknowledged by an operator located at either the MPS System HMI or the local alarm cabinet, the local alarm shall remain flashing until recovery occurs.

- After the alarm is acknowledged at the MPS System HMI, the audible signal shall be silenced.

- When recovery occurs (the leak or malfunction has been corrected) and after the local alarm is acknowledged, the local alarm shall cease illuminating."

2.18 PDS Requirement 3.2.4.4 - "The leak detection system sensors that are located in the pits shall be testable in place by the addition of water to the pit."

\subsection{Test results}

The AN-B Pit Leak Detector Test was satisfactorily performed and met all the referenced STEP requirements. Four Test Exceptions were written during the conduct of the test. Two are remarkable because they identify actual failure of components to perform their design function. The other two were generated to compensate for procedural inadequacies.

\subsection{Test Exception description and disposition}

\subsubsection{Test Exception 1}

During the conduct of the test relay K-231D failed. NCR W-314 (FDNW12) was written, the relay was replaced with like kind and testing was completed with no repeated failures. The relay replacement resulted in retesting of steps 5.4, 5.7, and 5.9.

\subsubsection{Test Exception 2}

During the conduct of Steps 5.10 and 5.11 the requirement was to read a voltage value of a nominal 24 Volts to verify that a contact configuration. The actual voltage readings were 22 Volts because of voltage drops across coils. "Nominal 24 Volts" was not defined as a qualitative value. The TE was written for clarification only. No impact on test or test results.

\subsubsection{Test Exception 3}

During the conduct of Steps 5.6 the requirement was to retain the test volume of water for a 24 -hour period. This was not achieved. Investigation determined that the pit drain plug had leaked. The plug was removed reworked. Step 5.6 was retested successfully. 


\subsubsection{Test Exception 4}

During the conduct of Steps 5.6 the requirement was to observe a 24

Volt reading. The procedure incorrectly identified the voltage value as 0 . ECN 649146 was issued to correct the error in the procedure.

3.2 Step 5.3 was reperformed because of ECN 654959, a misinterpretation of the probe elevation setting discovered during the testing of the AN-A Pit Leak Detector. This was incorporated into Test Exception 3 to ensure that the detectors have the same configuration.

3.3 PDS Requirement 3.2.1.3.3 is not fully satisfied because the "as built" system does not contain an audible alarm.

\subsection{Conclusions and Recommendations}

The test procedure is acceptable as written and performed. It provides adequate documentation that the system, as constructed, meets the basic design requirements and is ready to support advanced system testing and integration. 
HNF-4647, Rev. 0

\section{ATTACHMENT A}

$A-1 \quad-$ 


\begin{tabular}{|c|c|c|}
\hline $\begin{array}{l}\text { 2. To: (Receiving Organization) } \\
\text { Distribution }\end{array}$ & $\begin{array}{l}\text { 3. From: (originating organization) } \\
\text { TFRSO }\end{array}$ & $\begin{array}{r}\text { 4. Related Eor No.: } \\
\qquad N / A\end{array}$ \\
\hline $\begin{array}{l}\text { 5. Proj./Prog./Dept./0iv.: } \\
\text { W-314/TWRS }\end{array}$ & $\begin{array}{l}\text { 6. Design Authority/ Design Agent/Cog. } \\
\text { Engr.: } \\
\text { D.E. Bowers }\end{array}$ & 7. Purchase Order No.: \\
\hline \multirow{2}{*}{\multicolumn{2}{|c|}{$\begin{array}{l}\text { 8. Originator Remarks: } \\
\text { This EDT release the approved ATP's for the } 241-A N-A \text { and } B \\
\text { packages part of Project } W-314 \text {. }\end{array}$}} & $\begin{array}{l}\text { 9. Equip./Component Mo.: } \\
N / A\end{array}$ \\
\hline & & $\begin{array}{l}\text { 10. System/8ldg./facility: } \\
N / A\end{array}$ \\
\hline \multirow{3}{*}{\multicolumn{2}{|c|}{ 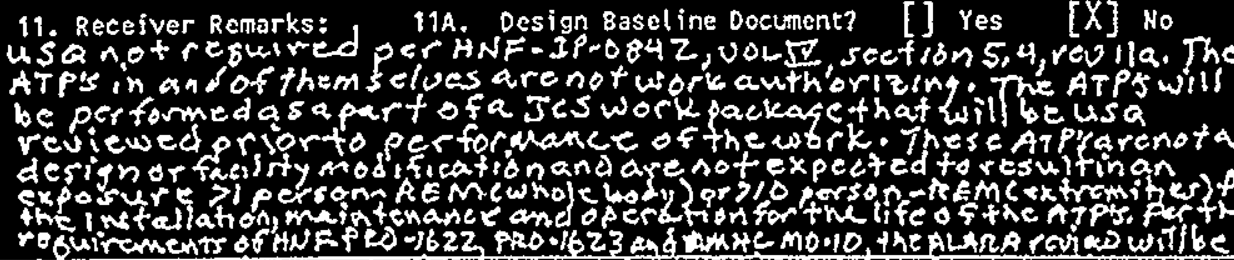 }} & $\begin{array}{l}\text { 12. Major Assm. Dug. No.: } \\
\text { N/A }\end{array}$ \\
\hline & & $\begin{array}{l}\text { 13. Permit/Permit Application No.: } \\
N / A\end{array}$ \\
\hline & & $\begin{array}{l}\text { 14. Required Response Date: } \\
\text { N/A }\end{array}$ \\
\hline
\end{tabular}

\begin{tabular}{|c|c|c|c|c|c|c|c|c|c|c|}
\hline \multicolumn{3}{|l|}{15.} & \multicolumn{4}{|c|}{ DATA TRAUSHITTEO } & \multirow{2}{*}{$\begin{array}{l}\text { (f) } \\
\text { Approval } \\
\text { Desig- } \\
\text { nator }\end{array}$} & \multirow{2}{*}{$\begin{array}{c}\text { (a) } \\
\text { Resson } \\
\text { for } \\
\text { Trans- } \\
\text { mittal }\end{array}$} & \multirow{2}{*}{$\begin{array}{l}\text { (H) } \\
\text { Origi- } \\
\text { nator } \\
\text { Oispo. } \\
\text { sition }\end{array}$} & \multirow[b]{2}{*}{$\begin{array}{l}\text { (I) } \\
\text { Recolv- } \\
\text { ef } \\
\text { Dispo- } \\
\text { sition }\end{array}$} \\
\hline $\begin{array}{l}\text { [A] } \\
\text { item } \\
\text { No. }\end{array}$ & \multicolumn{2}{|c|}{ (B) Document/Drawing No. } & $\begin{array}{l}\text { (C) } \\
\text { Sheet } \\
\text { No. }\end{array}$ & $\begin{array}{l}\text { \{D\} } \\
\text { Rev. } \\
\text { No. }\end{array}$ & \multicolumn{2}{|c|}{$\begin{array}{l}\text { (E) Titio or Doscription of Data } \\
\text { Transmitred }\end{array}$} & & & & \\
\hline 1 & \multicolumn{2}{|l|}{$\begin{array}{l}\text { ATP-W314-001 } \\
H N E-4642\end{array}$} & & 0 & \multicolumn{2}{|c|}{$\begin{array}{l}\text { 241-AN-A Valve pit Manlfold } \\
\text { Valyes \& Position Indication } \\
\text { ATp }\end{array}$} & $\begin{array}{l}\text { ES Q } \\
\text { Dsestat } 49\end{array}$ & 1 & 1 & 1 \\
\hline 1 & \multicolumn{2}{|l|}{$\begin{array}{l}\text { ATP-W314-002 } \\
H N E-4644\end{array}$} & & 0 & \multicolumn{2}{|c|}{$\begin{array}{l}241-A N-B \text { Valve Pit Manifold } \\
\text { Valves \& Position Indication } \\
\text { ATP }\end{array}$} & 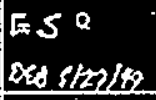 & 1 & 1 & 1 \\
\hline 1 & \multicolumn{2}{|l|}{$A T P=1314=003$} & & 0 & \multicolumn{2}{|c|}{$\begin{array}{l}241-A M-B \text { Pit Leak Detection } \\
\text { ANB-HT-LDSTA-231 AIP }\end{array}$} & Es a & 1 & 1 & 1 \\
\hline 1 & \multicolumn{2}{|l|}{ AIP-WB14-004 4 CE } & & 0 & \multicolumn{2}{|c|}{$\begin{array}{l}241-A N-A \text { Pit Leak Detection } \\
\text { AHA-HT-LOSTA-331 ATP }\end{array}$} & 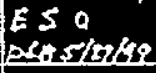 & 1 & 1 & 1 \\
\hline 1 & \multicolumn{2}{|l|}{$\begin{array}{l}A T P-W 314-005 \\
H N \dot{F}-4650\end{array}$} & & 0 & \multicolumn{2}{|c|}{$\begin{array}{l}\text { SW-268 Encasement Leak } \\
\text { Detection ANg-WT-1DSTA-335 } \\
\text { ATP }\end{array}$} & $\begin{array}{l}\text { Es } 0 \\
0,00 / 221 / 2\end{array}$ & 1 & 1 & 1 \\
\hline \multicolumn{11}{|l|}{16.} \\
\hline \multicolumn{2}{|c|}{ Approval Designator (F) } & \multicolumn{4}{|c|}{ Reason for Transmittal (G) } & \multicolumn{5}{|c|}{ Oisposition $|H|$ \& || $\mid$} \\
\hline \multicolumn{2}{|c|}{$\begin{array}{l}E, S, Q, D \text { or } N / A \\
\text { (see WHC-CM-3.5, } \\
\text { Sec.12.7) }\end{array}$} & $\begin{array}{l}\text { 1. Appr } \\
\text { 2. Rele: } \\
\text { 3. Infor }\end{array}$ & \multicolumn{3}{|c|}{$\begin{array}{l}\text { 4. Review } \\
\text { 5. Post-Review } \\
\text { 6. Dist. \{Recolpt Acknow. Requitedt }\end{array}$} & \multicolumn{2}{|c|}{$\begin{array}{l}\text { 1. Approved } \\
\text { 2. Approved w/commont } \\
\text { 3. Disapproved w/comment }\end{array}$} & \multicolumn{3}{|c|}{$\begin{array}{l}\text { 4. Reviewed no/comment } \\
\text { 5. Roviewed w/comment } \\
\text { 6. Receipt aeknowedged }\end{array}$} \\
\hline
\end{tabular}
17. SIGNATUREIOISTRIBUTION

(See Approval Designator for required eignatures]

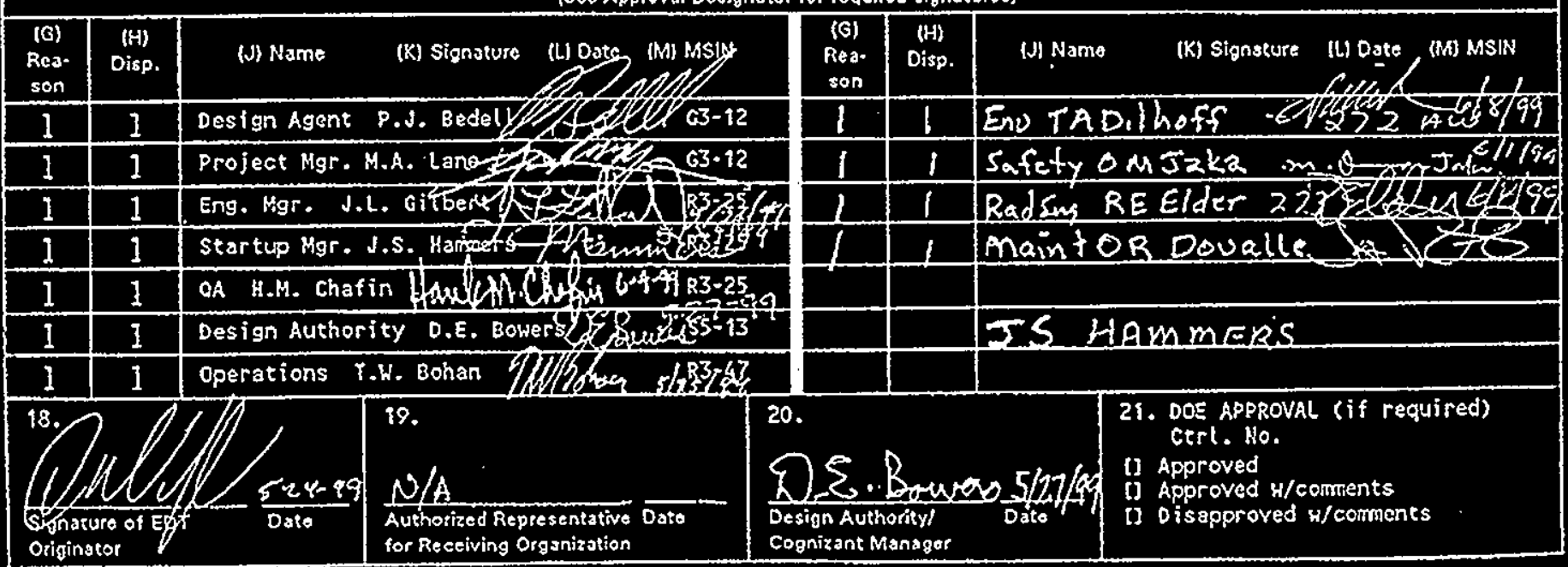

$$
\begin{aligned}
& H N F-46 C 7 \\
& \text { Cev } 0
\end{aligned}
$$


TWRS ADMINISTRATION

JOINT TEST REVIEN PROCESS
Manua 1

Volume

Section

Page

Effective Date
HNF-1P - 08842

II, Operations

4.1.3, REV 1a

7 of 12

March 23, 1999

\section{ATTACHMENT A}

JOINT TEST REVIEN GROUP APPROVAL

Procedure \# HNF-4646 (241-AN-B PIT LEAK DETECTION ANB-WT-LDSTA-231)

\section{TITLE}

\begin{tabular}{|l|l|l|}
\hline \multicolumn{1}{|c|}{ Position } & \multicolumn{1}{|c|}{ Name } & Phone \\
\hline Test Director/Supervisor & J. GRUBA & $373-1249$ \\
\hline $\begin{array}{l}\text { Engineering Manager or } \\
\text { Representative }\end{array}$ & D. G. BAIDE & $376-3274$ \\
\hline $\begin{array}{l}\text { Project Manager or } \\
\text { Representative }\end{array}$ & T. H. BOHAN & $373-1479$ \\
\hline $\begin{array}{l}\text { Design Authority } \\
\end{array}$ & D. E. BOWERS & $373-1849$ \\
\hline & & \\
\hline & & \\
\hline
\end{tabular}

Restrictions or Limitations:

Chief Test Director Approval:

RONALD L. LEGG

Printed Name

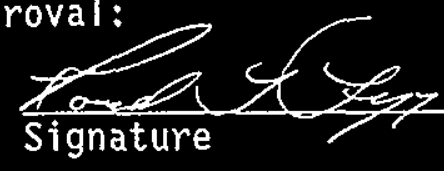

$\frac{c-22-8 g}{\text { Date }}$

$$
\begin{aligned}
& \text { HNF }-464 ? \\
& \text { TEDO }
\end{aligned}
$$




\section{1-AN-B Pit Leak Detection \\ ANA-WT-LDSTA-231 \\ Acceptance Test Procedure}

David H. Vandyke

Maintenance Concepts

Richland, WA 99352

U.S. Department of Energy Contract DE-ACO6-96RL13200

EDT/ECN: 626838

UC: 2030

Org Code: IJkz20000

B\&R Code: EW3130010

Charge Code: 106065

Total Pages: 48

Key Words: Acceptance Test Proceduxe

Abstract: This document describes the method used to test design criteria for Safety Class, Intristcally Safe leak detector system installed in 241-AN-B Valve Pit located at 200E Tank Faxms.

TRADEMARK DISCLAIMER. Reference herein to any specific commercial product, process, or service by trade name, trademark, manufacturer, or otherwise, does not necessarily consthute or imply its endorsement, recommendation, or favoring by the United States Government or any agency thereof or tis contractors or subcontractors.

Printed in the United States of America. To obtain copies of this document, contact: Document Control Servicas, P.O. BOx 950, Mallstop H8-08, Richland WA 99352, Fhone (509) 372-2420; Fax (509) 376-4989.
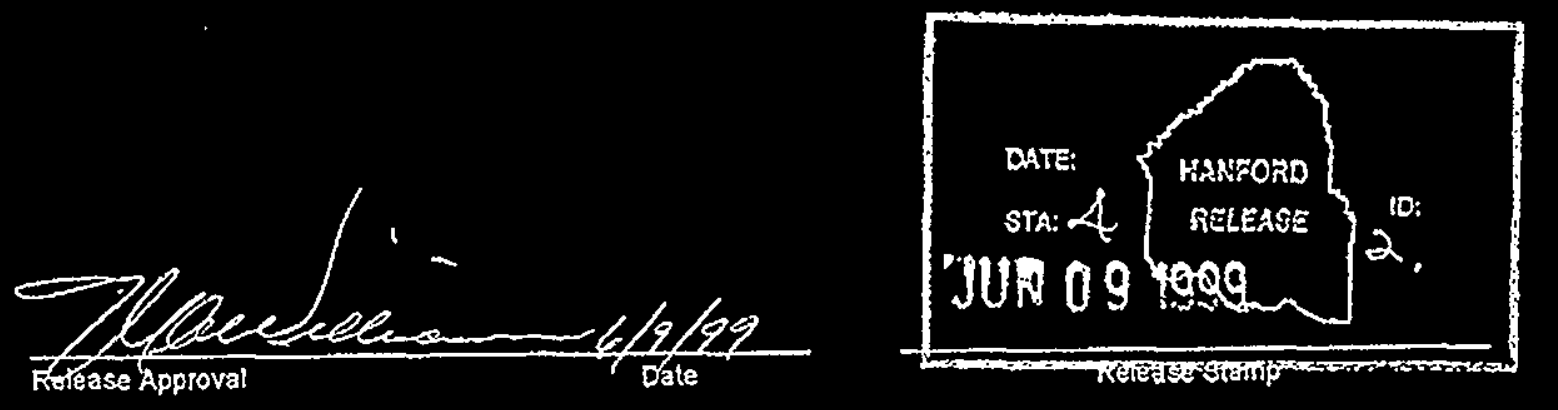

Approved For Public Release

$$
\text { Hef-4647 }
$$

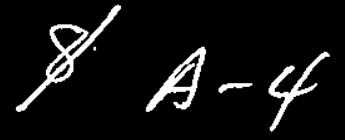

A-6400-073.1 (10/97) 


\section{1-AN-B PIT LEAK DETECTION ANB-WT-LDSTA-231 ACCEPTANCE TEST PROCEDURE}

$$
\begin{aligned}
& H N F-4607 \\
& \text { ReO }
\end{aligned}
$$

$$
\text { I A-S }
$$


TEST EXECUTION SHEET $\ldots \ldots \ldots \ldots \ldots$

1.0 PURPOSE AND SCOPE $\ldots \ldots \ldots \ldots$

1.1 PURPOSE .................... 4

$1.2 \quad \operatorname{SCOPE} \ldots \ldots \ldots \ldots . \ldots . \ldots . \ldots . \ldots 4$

2.0 INFORMATION $\ldots \ldots \ldots \ldots$

2.1 TERMS AND DEFINITIONS ................ 4

2.2 RESPONSIBILITIES ............... 4

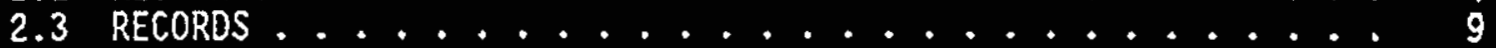

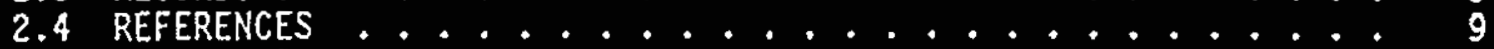

2.5 GENERAL INFORMATION ............... 10

3.0 PRECAUTIONS AND LIMITATYONS ................. 14

3.1 PERSONNEL SAFETY ..................... 14

3.2 RADIATION AND CONTAMINATION CONTROL .......... 14

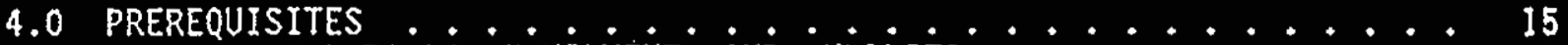

4.1 SPECIAL TOOLS, EQUIPMENT, ANB SUPPLIES $\ldots \ldots \ldots \ldots$

4.2 PERFORMANCE DOCUMENTS .............. 15

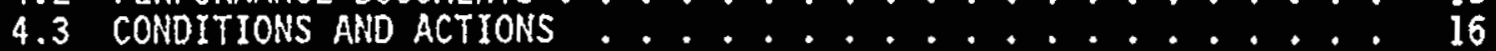

5.0 PROCEDURE .......................... 17

5.1 POWER REQUIREMENTS TEST . . ............ 17

5.2 SETTING THE MTL TRIP AMPLIFIER ............ 19

5.3 SETTING THE PROBE ELEVATIONS ............ 21

5.4 B/W LEAK DETECTION RELAY SWITCH TEST $\ldots \ldots . \ldots . \ldots 23$

5.5 LAMP TEST . . . . . 25

5.6 B/W LEAK DETECTION RELAY LEAK SIMULATION TEST . . . . 26

5.7 MTL FAIL SAFE RELAY SWITCH TEST $\ldots \ldots \ldots$

5.8 MTL FAIL SAFE RELAY SIMULATION TEST . . . ...... 35

5.9 REMOTE RESET TEST . ........................ 37

5.10 REMOTE TRIP AMPLIFIER VOLTAGE RELAY TEST ........ 39

5.11 REMOTE LEAK DETECTION RELAY TEST . . . . . . . . 41

ATP PERFORMANCE LOG .................... 43

ATP EXCEPTION LOG .......................... 44

ATP EXCEPTION RECORD ......................... 45

PROCEDURE SIGNATURE SHEET ................. 46

PROCEOURE HISTORY SIGNATURE SHEET . . . . . . . . . 47

$$
\begin{aligned}
& \text { HNF-4647 } \\
& \text { Revo }
\end{aligned}
$$




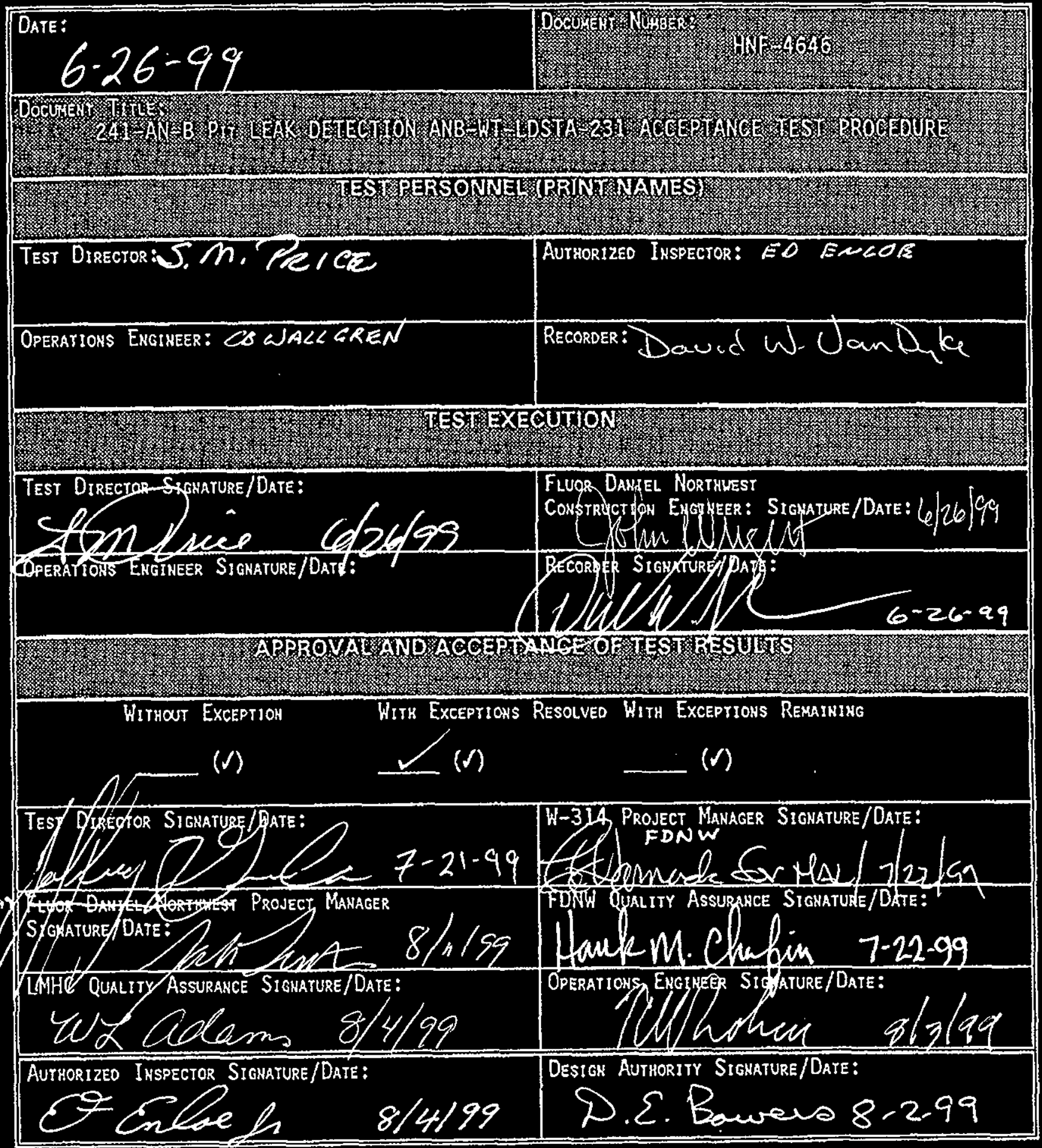




\subsection{PURPOSE AND SCOPE}

\subsection{PURPOSE}

The purpose of this Procedure is to demonstrate that the pit leak detection relay cabinet and intrinsically safe probe circuit is fully operable.

\subsection{SCOPE}

This Acceptance Test Procedure will test all functions of the ANB-WT-LOSTA-231 pit leak detection relay cabinet and associated components.

\subsection{INFORMATION}

\subsection{TERMS AND DEFINITIONS}
$2.1 .1 \quad$ ATR -
Acceptance Test Report
2.1.2 ATP -
Acceptance Test Procedure

\subsection{RESPONSIBILITIES}

2.2.1 Each company or organization participating in the conduct of this procedure wit designate personnel to assume the responsibilities and duties as defined herein for their respective roles. The names of these designees shall be provided to the Recorder for listing on the Working Copy of the Test Execution Sheet prior to the performance of any part of this procedure.

2.2.2 The Fluor Daniel Northwest Project Manager is responsible for the following:

1 Designation of a test director

- Signing the Test Execution Sheet when the Acceptance Test Procedure is approved and accepted as complete.

2.2.3 The Operations Engineer is responsible for the following: Setting the safe boundaries for performing this procedure

Ensuring plant configuration is in proper status for performing this procedure 


\subsection{RESPONSIBILITIES (cont.)}

Signing for operations where applicable in this procedure

Performing a Post-Test Review of Acceptance Test documentation

Obtaining concurrence from Tank Farm Shift Manager prior to commencing the test, or upon restart of testing after a temporary suspension of testing.

2.2.4 The Operations Representative is responsible for the following:

Ensuring that safe work boundaries for testing are complied with

Coordinating all support craft and personnel in field with the Test Director and the Construction Engineer

Obtaining release of this ATP for field testing from shift office.

2.2.5 The Test Director is responsible for the following:

Coordination of all acceptance testing

Signing the ATP Exception Record when a test exception has been resolved

Preparing and issuing an Acceptance Test Report for the approved and accepted Acceptance Test Procedure when testing is completed

Scheduling and conducting a pre-test meeting with acceptance test participants prior to start of testing

- Notification of the persons performing and witnessing the test prior to the start of testing 


\subsection{RESPONSIBILITIES (cont.)}

Notification of all concerned parties when a change is made in the testing schedule

Acting as liaison between the participants in acceptance testing

Stopping any test which may cause damage to the system until the Acceptance Test Procedure has been revised

Approving field changes to the Acceptance Test Procedure in accordance with Section 2.5.

- Obtaining revisions to the Acceptance Test Procedure, as necessary, to comply with authorized field changes or to accommodate existing field conditions in accordance with Section 2.5 .

Taking necessary actions to clear exceptions to the Acceptance Test Procedure

Evaluating recorded data, discrepancles, and exceptions

Signing Test Execution Sheet when this Acceptance Test Procedure has been performed

Signing ATP Exception Record when a retest to ciear an exception has been executed and accepted

Obtaining required signatures on the Acceptance Test Procedure Working Copy prior to reproduction and distribution.

2.2.6 The Recorder is responsible for the following:

Performing all recording duties using black ink

Recording the names of all designated personnel on the Working Copy of this procedure prior to start of testing

Observing tests, recording test data, and maintaining the ATP Performance Log 


\subsection{RESPONSIBILITIES (cont.)}

Signing the Test Execution Sheet as the Recorder

Initialing every test verification step requiring initials on the Working Copy of this Acceptance Test Procedure as that step is successfully performed, to indicate that Acceptance Criterion has been met

Recording authorized field changes to this Acceptance Test Procedure

Recording Test Exceptions and individual Test Procedure steps that are not performed satisfactorily on the ATP Exception Record and ensuring that the information is transferred (in ink or typed) to the master Horking Copy of ATP Exception Record(s). Additional ATP Exception Records are to be added as needed

Notifying the Test Director at the time any objection is made during performance of the Acceptance Test Procedure

Submitting the completed master Working Copy of this Acceptance Test Procedure to the Test Director for approval signatures and distribution.

2.2.7 The Construction Engineer is responsible for the following:

- Ensuring all equipment required for performing this Acceptance Test Procedure listed in Section 4.1 will be available at the start of testing

- Obtaining from the NHC and LMHC Project Engineer any information or changes necessary to clear or resolve objections

- Coordinating field personnel and activities with the Test Director and Operations Representative

- Ensuring that field testing and inspection of the system or portion of the system to be tested has been completed prior to start of this ATP

- Providing technical input to test personnel as needed relating to the configuration of equipment and systems to be tested and utilized in this procedure

- Post Review of Acceptance Test Documentation. 


\subsection{RESPONSIBILITIES (cont.)}

2.2.8 Fluor Daniel Northwest Quality Assurance is responsible for the following:

Review and approval of test exception resolutions

Performing a Post-Test Review of Acceptance Test documentation

Assisting Construction Engineer in Pre-Test verification of construction documentation (i.e. CHPs, submittals, receiving reports etc.

2.2.9 Lockheed Martin Quality Assurance is responsibje for the following:

Review and approval of test results

- Performing a Post-Test Review of Acceptance Test documentation

2.2.10 Fluor Daniel Hanford Authorized Inspector is responsible for the following:

Witnessing test execution

- Approval and signature of acceptance upon completion of this procedure.

2.2.11 Industrial Health And Safety Tech. is responsible for the following:

Monitor for toxic and combustible gases or vapors and report out of compliance levels to THRS Industrial Hygiene technician

Evaluate exposure potential using field data and according to HNF-SD-WM-HSP-002 or other industrial hygiene exposure prevention criteria and recording monitored levels in applicable steps in work package.

2.2.12 Quality Control is responsible for the following:

Witness and signing, $1 \mathrm{ift}$ land records and the installation and removal of all temporary wiring and devices as applicable in this procedure. 


\subsection{RECORDS}

2.3.I The completed master "Working Copy" of this Acceptance

Test Procedure, Acceptance test report, the completed "Test

Execution Sheet", the completed "ATP Performance $\log ^{\text {" }}$ and

"ATP Exception Log", and a 3 "Test Exception Sheets" generated during performance of this Acceptance Test Procedure will be kept as permanent records.

\subsection{REFERENCES}

2.4.1 The following documents were used to write or are referenced in this procedure:

- H-14-100930, "AN STRUCTURAL COVER BLOCKS 241-AN-B PLAN AND DETAILS"

- H-14-100936, SH. 1, "ELECTRICAL INSTALLATION DETAILS VALVE PIT $241-\mathrm{AN}^{-A^{\prime \prime}}$

- H-14-100942, "P \& ID VALVE PIT 241-AN-B"

- H-14-100978, "PIPING FLOOR DRAIN SEAL ASSEMBLY VALVE PITS 24I-AN-A\&B"

- H-14-100983, "INSTM LEAK DETECTION RELAY PNL, ASSY \& DETAILS"

- H-14-100989, SH. 2, "INSTM VALVE PIT LEAK DETECTION LDE-231 LOOP DIAGRAM"

- H-2-71931, SH. 1, "ELECTRICAL LEAK DETECTION ELEMENTARY DIAGRAMS"

- H-14-100937 "ELECTRICAL PANELBOARD SCHEDULE EDS-DP-105"

- H-14-100988, "INSTM FIELD TERMINAL BOX INTERCONNECTION DIAGRAM" 


\subsection{GENERAL INFORMATION}

2.5.1 Al1 steps in this Acceptance Test Procedure are performed at the 241-AN-B Valve Pit.

2.5.2 ACCEPTANCE CRITERIA: All Test Procedure steps using the word VERIFY are considered Acceptance Criteria steps, and each must have successful execution indicated by having initials and the date entered in the provided space to be considered complete.

2.5.3 All entries recorded in this procedure shall be frade in black ink, except for those noted using the rediline method.

2.5.4 Required editorial changes to this procedure may be made by the Test Director and Cognizant Engineer per

HNF-IP-0842, "Technical Procedure Requirements", as long as the changes do not impact operational facility safety function or performance, and will not compromise or influence the test data. Any technical change must be made by ECN.

2.5.5 Acceptance Test steps detailed in individual Tests in Section 5.0 shall be performed sequentially, unless - otherwise noted or as directed by the Test Director.

Individual Test Procedure Sections may be performed out of sequence at the direction of the Test Director, if the intent of the test is not compromised

As required by subsection 2.2.6, as each step is completed, the Recorder will check off (or enter "N/A" for), or initial each Test step as required in the spaces provided on the Working Copy of this Acceptance Test Procedure

Any step that requires verification of data must also include recording data on the Working Copy. 


\subsection{GENERAL INFORMATION (Cont.)}

2.5.6 It is the intent to perform this Acceptance Test Procedure uninterrupted from beginning to end. If testing is terminated due to time constraints at the end of an individual Test Section, the system will be placed in a safe configuration by the Test Director, with concurrence of the Operations Engineer, and the terminated test. configuration noted in the ATP Performance Log. The test will restart at the next scheduled shift by establishing the noted test configuration, and documenting this in ATP Performance $\log$.

2.5.7. Any non-conformance of the instrumentation, unexpected results or exceptions during testing shalt be sequentially numbered and recorded in the ATP Exception Log and on individual ATP Exception Records. Thus, case-by-case resolution, recording, approval, and distribution of each exception will be achieved.

2.5.8 When an exception is identified during testing, initiate an ATP Exception Record in the following manner (an example of a test exception would be when the system, fabricated per the design media, does not perform as expected):

Number each exception sequentially as it occurs and record it on the ATP Exception Log

Enter the sequential exception number, Date, and a description of the exception on an ATP Exception Record; identify additional detait as required

Enter the name and/or the organization of the objecting party for each exception in the "Description of Exception" section of the ATP Exception Record

Enter a description of actions planned to resolve each exception on the ATP Exception Record when such a determination is made. 


\subsection{GENERAL INFORMATION (Cont.)}

2.5.9 Resolve test exceptions in the following manner:

Record the action taken to resolve each exception in the "Resolution of Exception" section of the ATP Exception Record (the action taken does not have to be the same as the recorded planned action)

When the action taken results in an acceptable retest, inftial and date the Correction Approval section of the Exception Sheet

When the action taken does not result in an acceptable retest, provide a detailed explanation of why the retest action was not acceptable, and what additional plans are required. The explanation may include why the system should be Accepted-As-Is. The NHC Project Engineer then signs and dates the Resolution of Exception section of the ATP Exception Record, and obtains any other approvals required

- Distribute requisite copies of the completed ATP Exception Records to the client at the completion of the Acceptance Test Procedure.

2.5.10 Upon completion of the Acceptance Test Procedure, obtain approval of the test performance. Each Test Execution Sheet will stand alone as approval for the system under test. The Acceptance Test will be complete when all the outstanding tests have been performed and the Acceptance Test Report is prepared. The test will be approved by checking the proper response, with or without exceptions, on the Test Execution Sheet under the "Approval and Acceptance of Test Results" section of the Test Execution Sheet. 


\subsection{GENERAL. INFORMATION (Cont.)}

NOTE -

The following three steps detail the possible conditions that may exist at the completion of the Acceptance Test Procedure, and the steps necessary to complete Procedure acceptance in those conditions.

2.5.11 The completed test may be approved without test exceptions:

- Check applicable space on Test Execution Sheet to show that the Acceptance Test Procedure has been performed and no exceptions have been recorded

Appropriate individual Test Performers will sign and date the Test Execution Sheet in the spaces provided

- Distribute requisite copies as directed by the client

- Send the Master Copy of the completed Acceptance Test Procedure to the client.

2.5.12 The completed test may be approved with exceptions resolved:

Check applicable space on Test Execution Sheet to show that this procedure has been performed with exceptions recorded and resolved

Appropriate individual Test Performers will sign and date the Test Execution Sheet in the spaces provided

$r \quad$ Distribute requisite copies as directed by the client

- Send the Master Copy of the completed Acceptance Test Procedure to the client.

2.5.13 The completed test may be approved with test exceptions outstanding:

- Check applicable space on Test Execution Sheet to show that this procedure has been performed with exceptions recorded, part or all of which are presently outstanding, unresolved

Appropriate individual Test Performers will sign and date the Test Execution Sheet in the spaces provided

c Distribute requisite copies as directed by the client

( Send the Master Copy of the completed Acceptance Test Procedure to the client

( All outstanding exceptions shall be added to project punchl ist. 


\subsection{PRECAUTIONS AND LIMITATIONS}

\subsection{PERSONNEL SAFETY}

3.1.1 Individuals shall carry out their assigned work in a safe manner to protect themselves, others, and the equipment from undue hazards and to prevent damage to property and environment.

3.1.2 Operations Representative shall assure the safety of all activities within their areas to prevent injury, property damage, or interruption of operation.

3.1.3 Any hazard identified during the performance of the procedure shall be reported to the appropriate waste tank farm facility line manager.

3.1.4 A daily pre-job safety briefing will be held with all test participants and documented in the Pre-Job Safety form. (JSA or Pre Job Safety form)

3.1.5 Performance of test activities shall always include safety and health aspects as delineated in the Operations Manuals and as directed by the Test Director.

3.1.6 An Energized Work Permit is needed to perform this procedure.

\subsection{RADIATION AND CONTAMINATION CONTROL}

3.2.1 Work in Radiological Areas will be performed using an approved Radiation Work Permit, following review by Radiological Control per the ALARA Program (HNF-IP-0842, Volume VII, Section 1.1). 


\subsection{PREREQUISITES}

\subsection{SPECIAL TOOLS, EQUIPMENT, AND SUPPLIES}

4.1.1 The following supplies shall be available at the test site:

(Electrician protective gloves

- Electrician protective eyewear (goggles or face shield)

Calibrated Volt Ohm Meter (Fluke)

- Long-shank lockout padlock

- Ruler, with minimum scale markings of $1 / 16$ inch

Fuse Puller

- Torquing Screwdriver (0-20 inch 1bs)

- 24 volt de Power Supply.

- Adjustable Voltage source 0-10 Volt dc

single pole, single throw switch rated (minimum) 5 amp 120 Vac

Salt Approx. $10 \mathrm{tsp}$.

- 10 Gallon container (minimum) for "Potable water" with ability to regulate flow out of container to (1 Gal/Hr).

NOTE - Calibrated electrical test equipment data shall be recorded at the beginning of each individual test section.

\subsection{PERFORMANCE DOCUMENTS}

The following procedures may be needed to perform this procedure:

$$
\text { As-Built Orawings }
$$




\subsection{CONDITIONS AND ACTIONS}

The following conditions must be met before this Acceptance Test Procedure (ATP) may commence.

NOTE- A jumper has been installed preventing Master Pump Shut down. This jumper shall be part of the inspection of system to be tested.

NoTE- All signators on this procedure shall document their signature on Procedure Signature Sheet.

4.3.1 All field festing and inspection of the system or portions of the system to be tested has been completed.

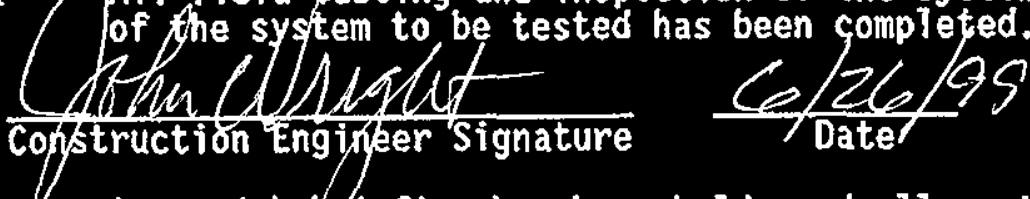

4.3.2 A pre-job briefing has been held. and all participants have been thoroughly briefed on job safety, hazards, and their responsibilities before performing this ATP.

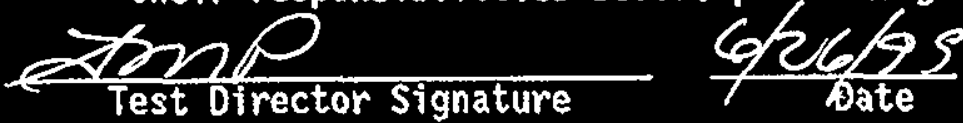

4.3.3 VERIFY all personnel responsible for directing, witnessing, and performing and signing the ATP have read and understand the ATP.
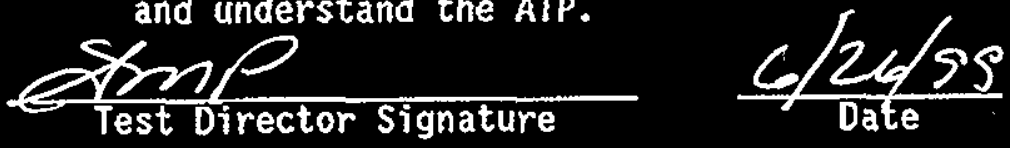

4.3.4 Test Director VERIFY that 241-AN-B Valve Pit is isolated from all other tanks.

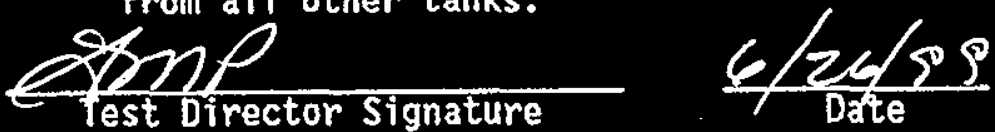

4.3.5 VERIFY with Shift Manager that NO transfers are occurring or planned during the time period of the test, by SIGNING below.
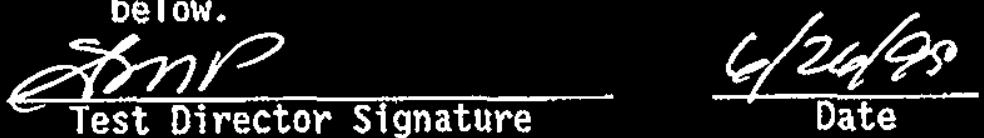

4.3.6 VERIFY IH\&S Tech. has performed monitoring of pit and signed in applicable sections of work package.

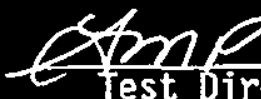

Test Director Signature

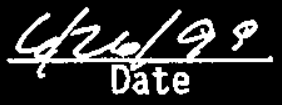

4.3.7 Test Director VERIFY Section 4.0 has been COMPLETED by SIGHING below.

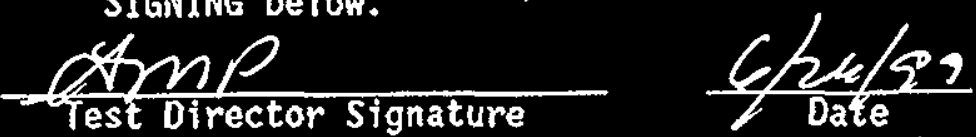




\subsection{PROCEDURE}

NOTE - These tests may require certain individuals to carry and operate hand held communication devices. This is necessary for communications from the AN Tank Farm Testing area to the 241-AN-271 building while generating alarms.

\subsection{POWER REQUIREMENTS TEST}

ELECTRICAL TEST EQUIPMENT DATA TABLE

\begin{tabular}{|c|c|c|c|}
\hline TOOL NAME & ID. NUMBER & CAL DUE DATE & INITIAL/DATE \\
\hline Eluke 20 III & 69431061 & 31 - July-99 & DV $/ 6-26-99$ \\
\hline & & & \\
\hline & & & \\
\hline
\end{tabular}

CIRCUIT BREAKER RATINGS

DV 5.1.1 LOCATE AND VERIFY that 120 Vac circuit breaker, circuit No. 30 in panelboard EDS-DP-105 (reference drawing H-14-100937, ELECTRICAL PANELBOARD SCHEDULE) has a trip rating of 20 Amps.
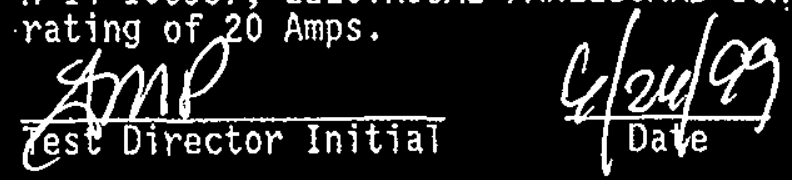

VOLTAGE VERIFICATION

PU 5.1.2 REMOVE cover of electrical panelboard EDS-DP-105.

NOTE - Voltage in the following step should be between 114 to 126 volts.

DV. 5.1.3 HEASURE AKD RECORD, using a volt/ohm meter, the main bus voltage from phase $A$ to ground.

$$
\text { VOLTAGE } 120.3 \text { VAC }
$$

QU 5.1.4 WEASURE AND RECORD, using a volt/ohm meter, the main bus voltage from phase $B$ to ground.

$$
\text { VOLTAGE } 120 \times 3 \text { VAC }
$$

DV 5.1.5 ENSURE circuit breaker 30 in Panelboard EDS-DP-105 is in the CLOSED or oN position. 


\subsection{POWER REQUIREMENTS TEST (Cont.)}

NOTE - Voltage in the following step should be between 114 to 126 volts.

DV 5.1.6 MEASURE AND RECORD the load side voltage of circuit No. 30 to ground.

\section{VOLTAGE 120.4 VAC}

NA 5.1 .7

If voltage is NOT within the $114-126$ volt range THEN IDENTIFY AND CORRECT VOTtage deficiency, AND REPEAT Step 5.1 .6 .

PV 5.1 .8
DV 5.1 .9

REPLACE cover of electrical panelboard EOS-DP-105.

ENSURE that panel ANB-WT-LDSTA-231 disconnect switch ANB-WT-DS-231 is in the OPEN Or OFF position AND Tocal strobe light alarm is DEACTIVATED.

NOTE - Voltage should be between 114 and 126 Volts. It may be necessary to remove the Tine shield Item No. 39 , drawing H-14-100983, attached to the disconnect switch Item No. 35 , drawing $\mathrm{H}-14-100983$, to verify voltages. Disconnect power to the leak detection relay cabinet by opening circuit breaker No. 30 panelboard EDS-DP-105, before attempting to remove the disconnect line shield. If the line voltage does not fall between the above voltage range, identify and correct the wiring deficiency to ANB-WT-LDSTA-231.

DV 5.1.10 MEASURE AND RECORD the voltage supplied to panel ANB-HT-LDSTA-23I.

$$
\text { VOLTAGE_120.5 VAC }
$$

$\operatorname{MV}_{5.1 .12}$

REPLACE line shield removed on the previous Step, if necessary.

ENSURE disconnect switch ANB-WT-DS-231 for ANB-WT-LDSTA-231 is left in the ON or CLOSED position.

5.1.13 VERIFY/thaj Teşt 5.1 is COMPLETE by SIGNING below.

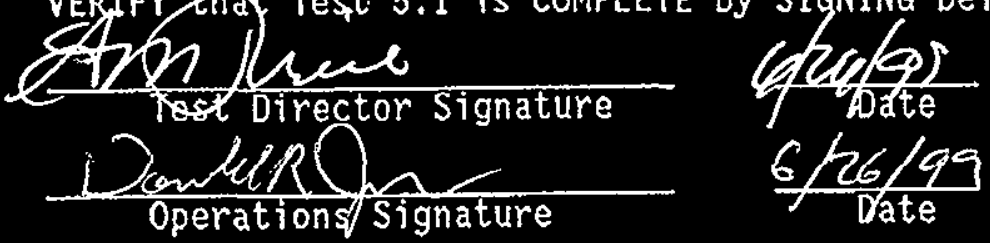




\subsection{SETTING THE MTL TRIP AMPLIFIER}

NOTE - The following set-up must be completed before further testing. The MTL Trip Amplifier (Item No. 22, Drawing No. H-14-100983) must be set prior to testing the leak detection relay cabinet assembly.

ELECTRICAL TEST EQUIPMENT DATA TABLE

\begin{tabular}{|c|c|c|c|}
\hline TOOL NAME & ID. NUMBER & CAL DUE DATE & INITIAL/DATE \\
\hline FLuter VOM & 0840 & $7 \cdot 28-99$ & Nad $6-27-99$ \\
\hline $\begin{array}{l}\text { TORQRUR } \\
\text { SCRE DRIUR }\end{array}$ & $950-88.01-087$ & $6-9-00$ & 2216.27 .99 \\
\hline
\end{tabular}

AN 5.2.1 DEENERGIZE the leak detection relay panel ANB-WT-LDSTA-231 AND OPEN the front door.

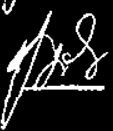

5.2 .2
DISCONNECT AND ISOLATE electrically, probe circuit wire ANB-WT-LDE-231B-2(-) at terminal block ANB-NT-TB-231-12. Ref. Dwg. H-14-100989 sh.2.

(ब)

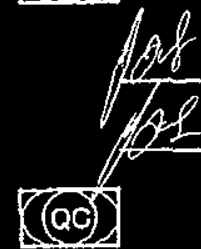

5.2.3 QC RECORD lifted wire data on Lift/Land table below.

5.2.4 DISCONNECT AND ISOLATE electrically circuit wires ANB-WT-LD-231-2 at reTay ANB-WT-K-231C. (2 Wires).

121

5.2 .5

QC RECORO lifted wire data on Lift/Land table below.

LIFT / LANO TABLE

\begin{tabular}{|c|c|c|c|c|c|c|}
\hline 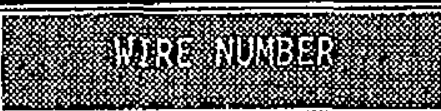 & Notip & manco & 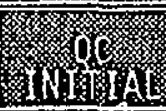 & Nor & 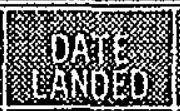 & y. \\
\hline ANB & 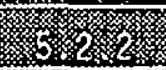 & $6-27-9$ & & 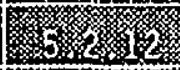 & CO279 & \\
\hline 作 & 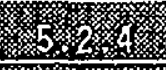 & 10.27 .99 & & 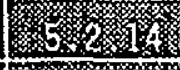 & & \\
\hline (x) & 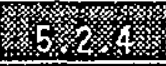 & $6.2)$ & & & & \\
\hline
\end{tabular}

212

5.2 .6

A28
ENERGIZE the leak detection relay panel ANB-HT-LDSTA-231 AND ACTIVATE the "ALARM RESET" Switch ANB-WT-PB-231C.

5.2.7 VERIFY AND RECORD on TABLE 1 the initial state of each output set of contacts on Voltage Relay/Trip Amp. ANB-WTEY-231 (Termina) No.'s 10 \& 11 and 13 \& 14 , Drawing No. H-14-100989, SH, 2) as OPEN Or CLOSED with the use of the volt $/ \mathrm{ghm}$ meter.

$\frac{28}{\text { Testyirector Initial }} \frac{6.27 .99}{\text { Date }}$ 
5.2 SETTING THE MTL TRIP AMPLIFIER (Cont.)

pols 5.2 .8

427.2 .9

125.2 .10
APPLY 1.5 volts dc using $0-10$ volt dc adjustable source to Item No.22, Drawing No. H-14-100983, on terminals 1 and 4. (This can be done using terminals 10 \& 12 on Term Block).

ADUUST the set point potent iometer of the MTL Trip

Amplifier (It tem No. 22, Drawing No. H-14-100983) until it actuates or the output contacts change state from the state recorded above at the applied 1.5 Volts dc.

VERIFY AND RECORD on TABLE 1, the state of each set of contacts after adjusting the set point potentiometer. Each contact verified in step 5.2 .7 should have changed state.

TABLE 1

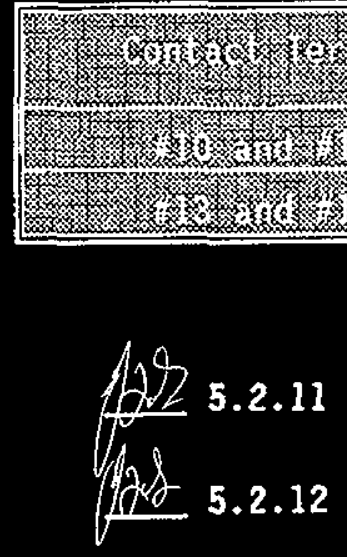

(ख)

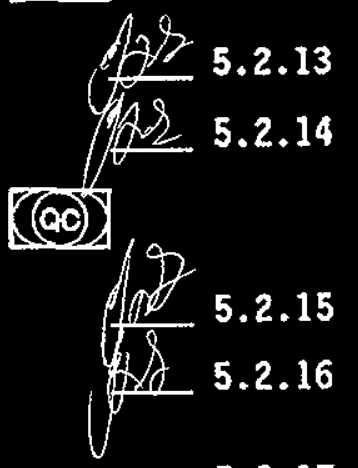

5.2 .17
QC RECORD landed wire data on Lift/Land table.

REPLACE BOTH circuit wires ANB-WT-LD-231-2 at re1ay ANB-WT-K-23IC AND TORQUE termination screw to 7 inch/lbs.

QC RECORD landed wire data on Lift/Land table.

ClOSE the panel door.

VERIFY/that Test 5.2 is COMPLETE by SIGNING below.

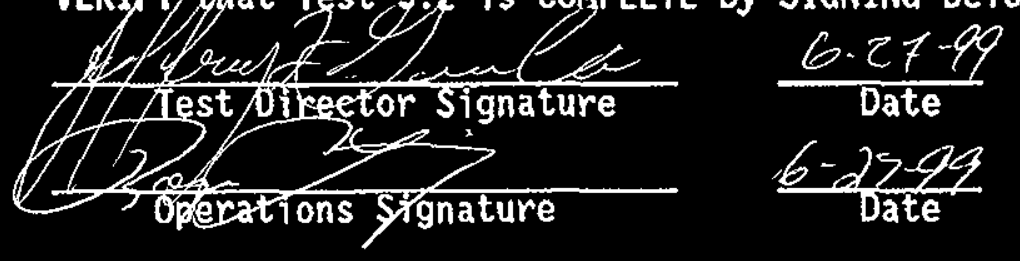




\subsection{SETTING THE PROBE ELEVATIONS}

5.3.1 VERIFY IH\&S Tech. has monitored pit prior to performing this section.

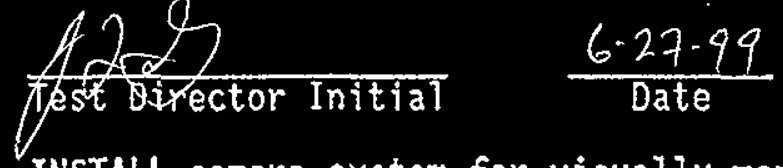

5.3.2 INSTALL camera system for visually monitoring probe and cables to probes per T0-020-005.

ELECTRICAL TEST EQUIPMENT DATA TABLE

\begin{tabular}{|c|c|c|c|}
\hline TOOL NAME & ID. NUMBER & CAL DUE DAJE & INITIAL/DATE \\
\hline$\Lambda / A$ & & & \\
\hline$\Lambda / A$ & & & \\
\hline$N / A$ & & & \\
\hline
\end{tabular}

5.3.3 VERIFY the probes are installed correctly. Refer to drawing H-14-100981, sht 1 \& 2, "INSTM PIT LEAK DETECTOR ASSY".
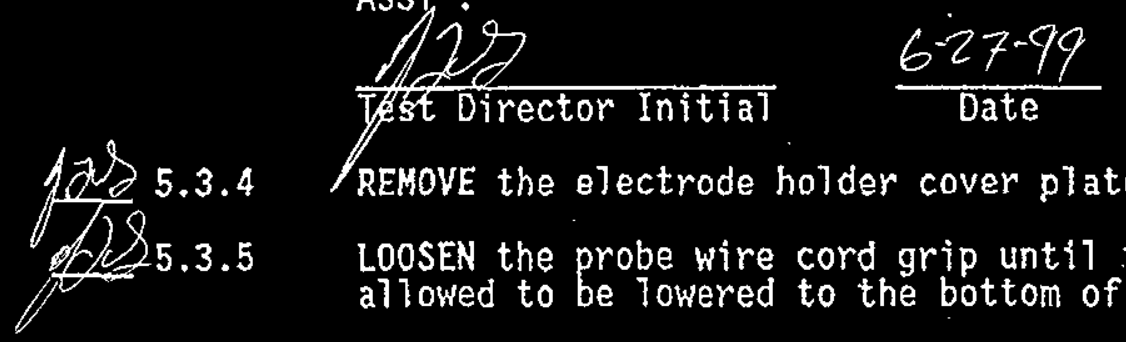

REMOVE the electrode holder cover plate.

LOOSEN the probe wire cord grip unti1 the probe wires are allowed to be lowered to the bottom of the pit floor.

NOTE - DO NOT allow slack to accumulate in the probe wires once the probes have touched the bottom of the pit floor. observe with camera system.

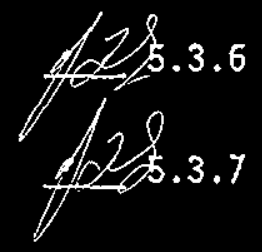

LOWER the probe wires toward the valve pit floor until the probes are just touching the pit floor.

HARK the probe wires at the top of the probe wire cord grips with the use of a permanent marker or other marking device.

RAISE the probe wires AND MEASURE a distance, down toward the electrodes, of $3 / 8(0.25$ to 0.5$)$ inches.

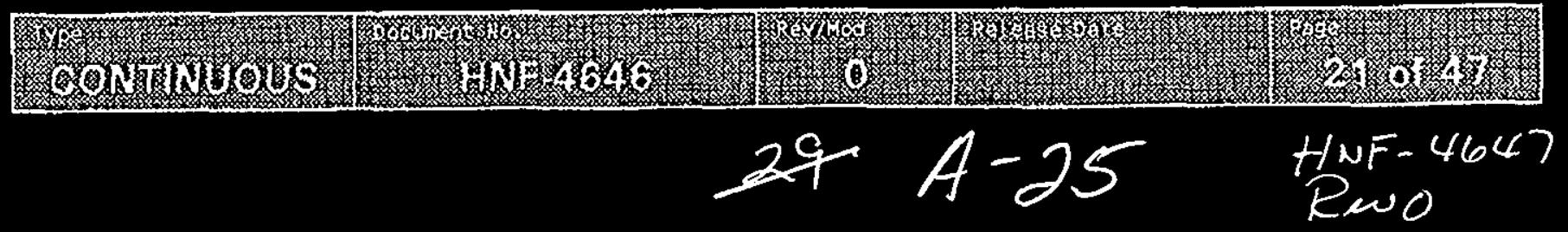




\subsection{SETTING THE PROBE ELEVATIONS (Cont).}

\subsection{9, MARK the probe wires at $3 / 8(0.25$ to 0.5$)$ inches down from the mark identified in step 5.3.7 Refer to drawing H-14-100986, sht 1, "INSTM 241-AN-B VALVE PIT ELEVATION \& DETAILS", for tolerances in this measurement.}

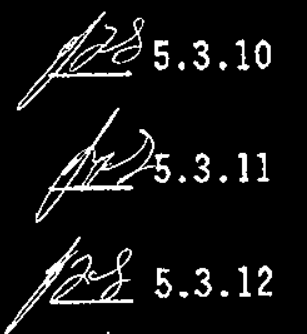

\section{LOWER the probes back toward the valve pit floor until the} lower mark is at the top of the probe wire cord grips.

\section{TIGHTEN the probe wire cord grip, at the position} indicated in Step $5.3,9$.

5.3 .12

VERIFY the cord grips are tightened at the mark made in Step, 5.3 .9 .

\&

5.3 .13

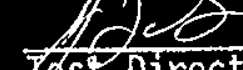

Jest Director Initial

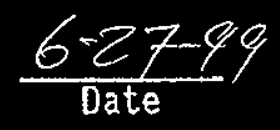

REPLACE the electrode holder cover plate.

5.3.14 VERFFY/that Test 5.3 is COMPLETE by SIGNING below.

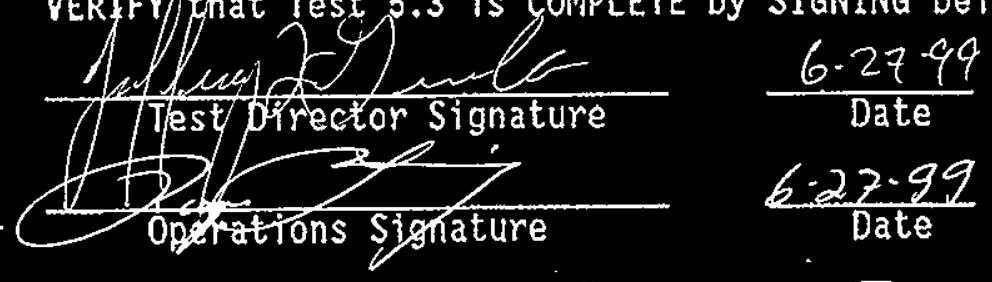

SEE TEST EXCEPTION \# RETEST 


\subsection{BN LEAK DETECTION RELAY SWITCH TEST}

NOTE - This test verifies the functionality of the $B / W$

intrinsically safe relay. By rotating the selector switch to the "PROBE TEST" position, an internal resistor simulates a load across the probes and activates the $8 / W$ intrinsically safe leak detection relay.

ELECTRICAL TEST EQUIPMENT DATA TABLE

\begin{tabular}{|l|l|l|l|}
\hline TOOL NAME & ID. NUMBER & CAL DUE DATE & INITIAL/DATE \\
\hline ELUKE VOM & 0840 & $7.28-99$ & 2.2 \\
\hline & & & \\
\hline & & & \\
\hline
\end{tabular}
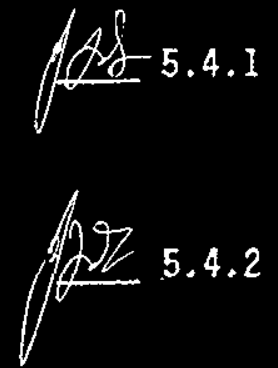

5.4 .2
LOCATE AND ENSURE that ANB-HT-LDSTA-231 disconnect switch ANB-WT-DS-231 (Drawing No. H-14-100989) is in the CLOSED position or ON, AND the local alarm strobe light is deactivated.

ROTATE selector switch ANB-WT-SS-231 to the "PROBE TEST" position, THEN RELEASE allowing spring return to the "Operate" position.

tod 5.4 .3

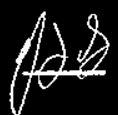

5.4 .4

1292

5.4 .5
VERIFY that the local strobe light alarm ANB-WT-LDA-231A located on ANB-WT-LDSTA-231 is activated.

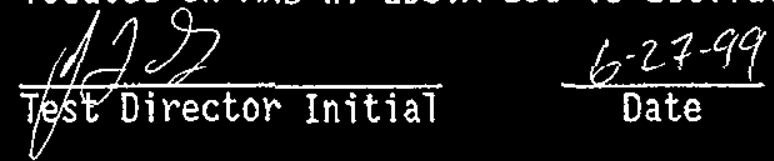

ROTATE AND HOLD selector switch ANB-WT-SS-231 to the "PROBE TEST" position.

HEASURE AND RECORD the voltage BETHEEN Terminal TB-DC2-35 and TB-DC2-34 in Field Terminal BOX AN241-WT-TBX-101.

VOLTAGE $\quad 0.0$ 


\subsection{BN LEAK DETECTION RELAY SWITCH TEST (Cont).}

M2 5.4.6 VERIFY the voltage recorded in Step 5.4.5 is at a nominal value of "O" Voits dc.

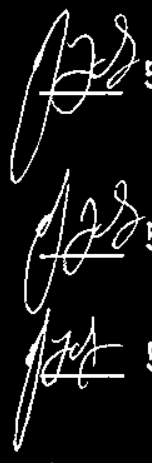

5.4.7 RELEASE selector switch ANB-WT-SS-331 from the "PROBE TEST" position. (Switch should return to "OPERATE" position).

5.4.8 LOCATE AND ACTIVATE the "ALARM RESET" Switch ANB-WT-PB-231C.

5.4.9 VERIFY the local strobe light alarm in Step 5.4.3 is NOT

operating:Dis Dater Initial

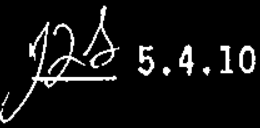

MEASURE AND RECORD the voltage BETWEEN Terminal TB-DC2-35 and TB-DC2-34 in Field Terminal BoX AN241-WT-TBX-101.

$$
\text { VOLTAGE } 24.02
$$

$2 / 25.4 .11$ VERIFY the voltage recorded in Step 5.4.10 at a nominal value of "24" Volts dc.

$$
\frac{12 t 26-99}{\text { Test Director Initial }}
$$

5.4.12 VERIFY that Test 5.4 is COMPLETE by SIGNING below.

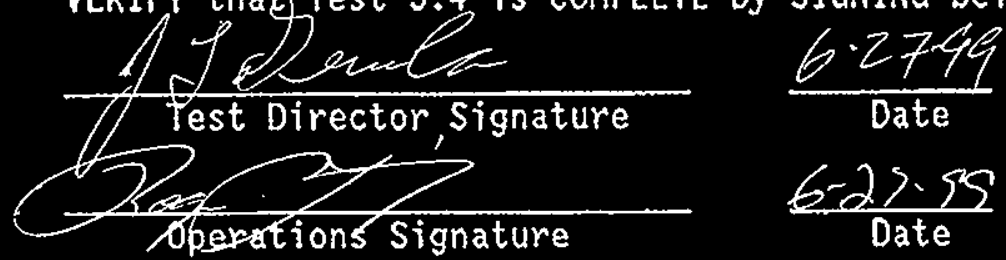




\subsection{LAMP TEST}

NOTE - The "LAMP TEST" push-button ANB-WT-PB-231E is designed to test the strobe light and audible alarm from the field. The following procedure demonstrates how to perform this function.

ELECTRICAL TEST EQUIPMENT DATA TABLE

\begin{tabular}{|c|c|c|c|}
\hline TOOL NAME & ID. NUMBER & CAL DUE DATE & INITIAL/DATE \\
\hline$N / A$ & & & \\
\hline$N / A$ & & & \\
\hline$N / A$ & & & \\
\hline
\end{tabular}

5.5.1 ENSURE that ANB-HT-LDSTA-231 disconnect switch

ANB-WT-DS-231, drawing reference No. H-14-100989, SH.2, is in the CLOSED position or ON AND local strobe light alarm is DEACTIVATED.

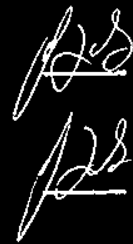

5.5 .2

DEPRESS the "LAMP TEST" push button switch ANB-KT-PB-231E, Drawing No. H-14-100989, SH. 2, AND HOLD.

5.5.3 VERIFY that the local strobe light alarm ANB-WT-LDA-231A, Drawing No. H-14-100989, SH. 2, is activated.
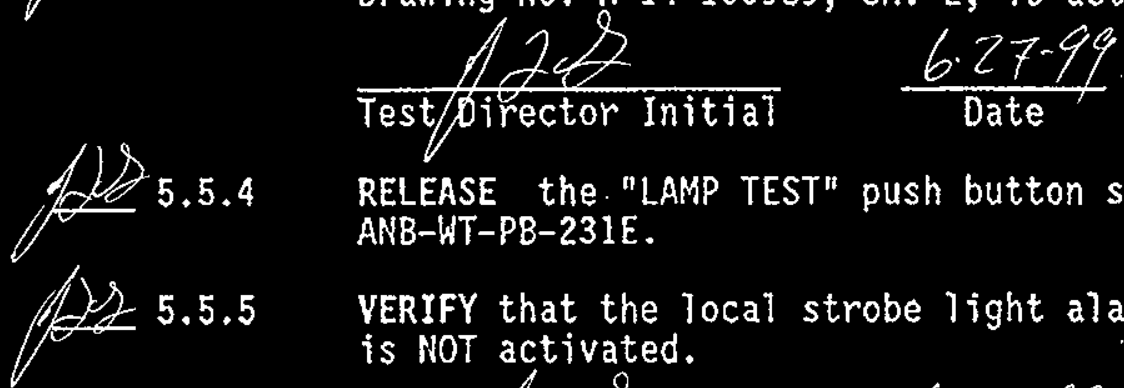

RELEASE the "LAMP TEST" push button switch ANB-WT-PB-231E.

VERIFY that the local strobe light alarm ANB-WT-LDA-231A is NOT activated.

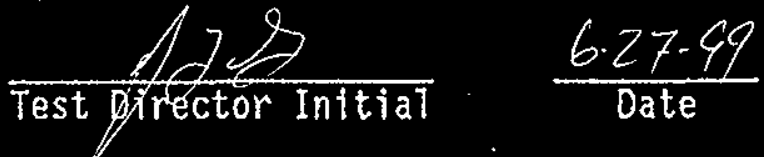

5.5.6 VERIFY that Test 5.5 is COMPLETE by SIGNING below.

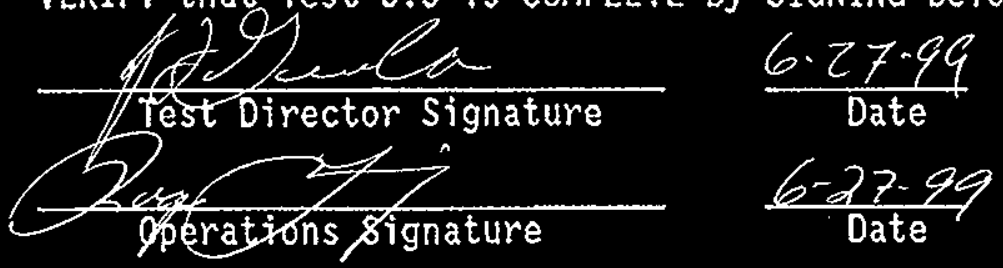




\subsection{BN LEAK DETECTION RELAY LEAK SIMULATION TEST}

NOTE - The B/W leak detection relay leak simulation tests the probe circuit by adding liquid to the 241-AN-B valve pit. Adding Salt water to the 241-AN-B vaive pit will be detected by the probe circuit and local alarms and remote signals will be generated.

ELECTRICAL TEST EQUIPMENT DATA TABLE

\begin{tabular}{|l|l|l|l|}
\hline TOOL NAME & ID. NUMBER & CAL DUE DATE & INITIAL/DATE \\
\hline FLUKE VOM & 1055 & 7.31 .99 & 2 \& $7-1.99$ \\
\hline & & & \\
\hline & & & \\
\hline
\end{tabular}

128.6 .1

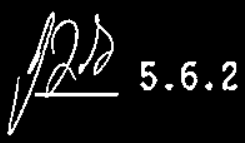

ENSURE that ANB-WT-LDSTA-231 disconnect switch ANB-WT-DS-23I, Drawing No. H-14-100989, SH. 2, is in the CLOSED position or ON, AND local strobe light alarm is DEACTIVATED.

VERIFY the low point drain assembly, drawing reference H-14-100978, "FLOOR DRAIN SEAL ASSEMBLY", is in the CLOSED, unretracted position.
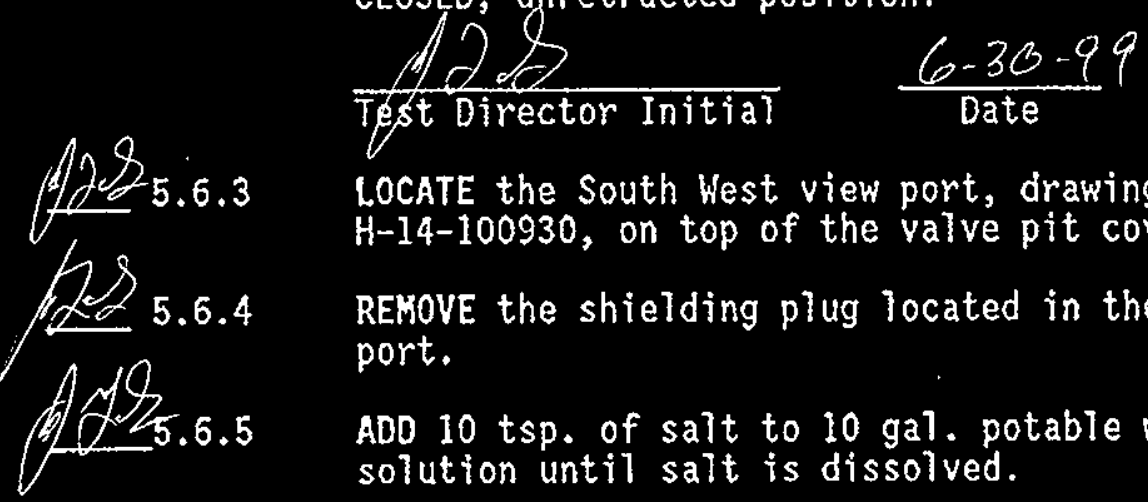

LOCATE the South West view port, drawing reference H-14-100930, on top of the valve pit cover block.

REHOVE the shielding plug located in the cover block view port.

ADD $10 \mathrm{tsp}$. of salt to $10 \mathrm{gal}$. potable water and stir solution until salt is dissolved.

NOTE - Use care to avoid splashing salt solution on jumpers in. pit during water addition.

NOTE - In the following step 1 iquid will be introduced to the pit. At a rate not to exceed $16 \mathrm{oz} . / \mathrm{min}$. (Maximum of 10 gal. tota1).

NOTE - Stop adding liquid to pit when leak detection alarm actuates.

1.25.6.6

POUR Salt Water solution into the view port.

SEE

TE $\$$ RETEST 
5.6 BN LEAK DETECTION RELAY LEAK SIMULATION TEST (Cont.)

1295.6 .7

RECORD, On TABLE 2 the start time for the liquid being poured into the valve pit.

TABLE 2

\begin{tabular}{|c|c|c|}
\hline 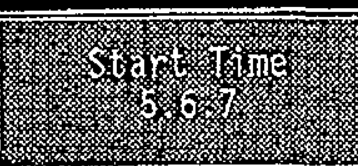 & 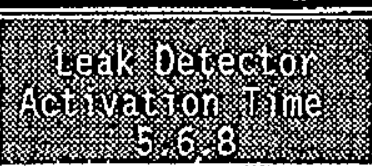 & 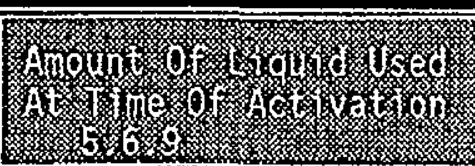 \\
\hline 2210 & 7240 & $3,75 \mathrm{Gol}$ \\
\hline
\end{tabular}

dm 5.6 .8

tom 5.6 .9

th.6.10

RECORO, On TABLE 2 the time the leak detector activates.

RECORD, On TABLE 2 the amount of salt water solution required to activate the leak detector.

VERIFY the amount of salt water solution required to activate the leak detector is less than or egual to 10 gallons.
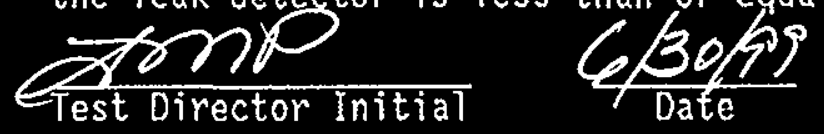

$\lim _{5.6 .11}$

VERIFY that the local strobe 1ight alarm ANB-WT-LDA-231A located on ANB-WT-LDSTA-231 is activated.

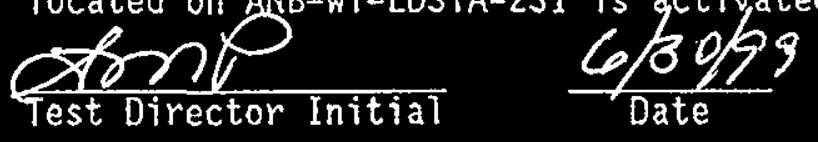

NOTE - The MPS is jumpered out and MPS system should NOT receive a $\rho$ shutdown signal.

frof 5.6.12. ADD remaining liquid using caution not splash solution on jumpers and devices in pit.

Anf 5.6 .13

RECORD on ALARM RESET DATA TABLE, the time liquid addition is complete.

$4 m / 5.14$

rin?

INSTALL shield plug removed in step 5.6 .4 .

LOCATE AND ACTIYATE the "ALARM RESET" Switch ANB-WT-PB-231C

located on ANB-HT-LDSTA-231.

exp.6.16

VERIFY the TOgal strobe 7 ight alarm remains operational.
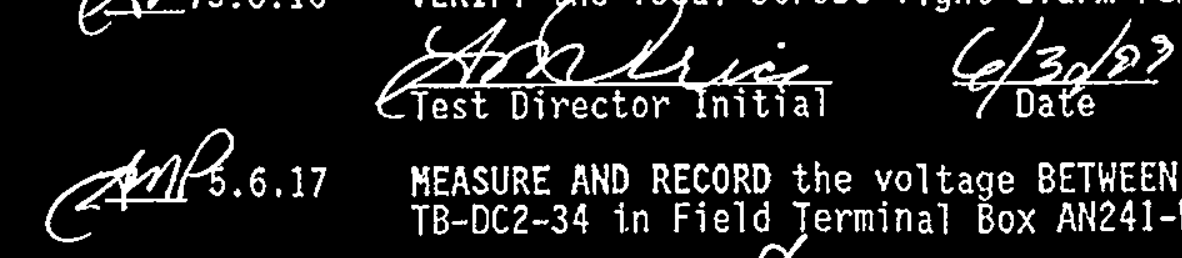

SEE

TE 3 RETEST

MEASURE AND RECORD the voltage BETHEEN Terminal TB-DC2-35 and TB-DC2-34 in Field Terminal BOX AN241-WT-TBX-101.

VOLTAGE 


\subsection{BN LEAK DETECTION RELAY LEAK SIMULATION TEST (Cont.)}

Cemp.6.18 VERIFY the voltage recorded in Step 5.6.17 at a nominal value of "on" volts dc.
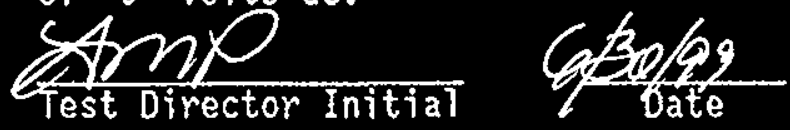

NOTE - During the next 24 hour period the ALARM reset switch ANBWT PB-231C Tocated on ANB-WT-LOSTA-231 will be actuated at leäst once every 60 minutes until al arm condition clears, or the 24 hour period is exceeded. It is recommended to attempt reset of alarm every 30 mins. (The intent of this is to fulfill the $24 \mathrm{hr}$. requirement for drain seal).

LOCATE AND ACTIVATE the "ALARM RESET" Switch ANB-WT-PB-23IC At least once every 60 min until alarm clears or 24 period is exceeded.

RECORD each RESET attempt on ALARM RESET DATA TABLE.

SEE

TE*3RETEST 


\subsection{BN LEAK DETECTION RELAY LEAK SIMULATION TEST (Cont/\%)/\%}

ALARM RESET DATA TABLE Time of Liquid Addition Completion $2240^{-14} 2254$

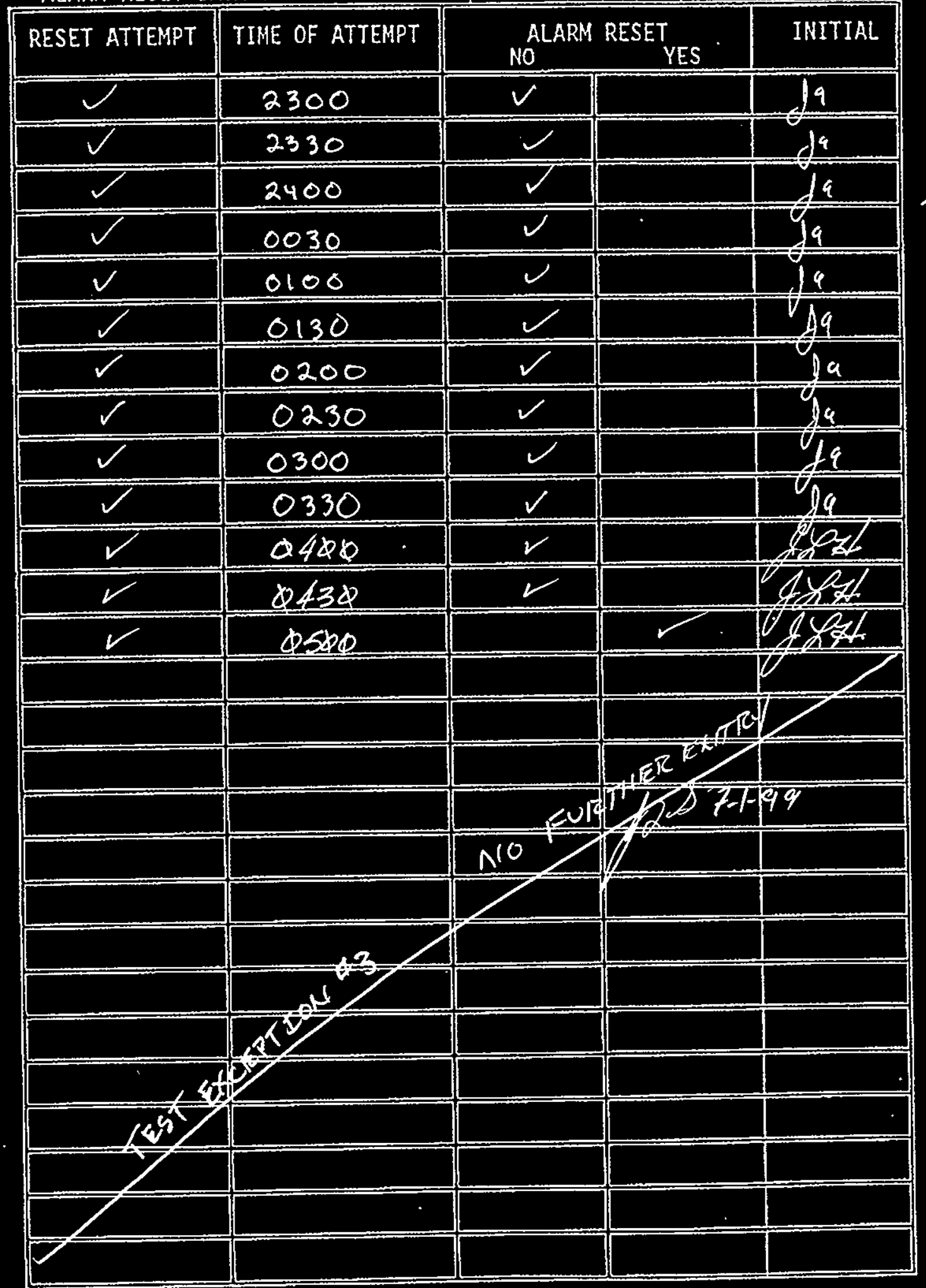

$7-1-99$ 


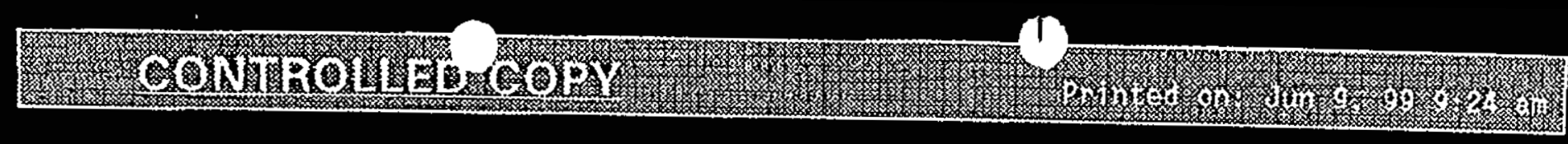

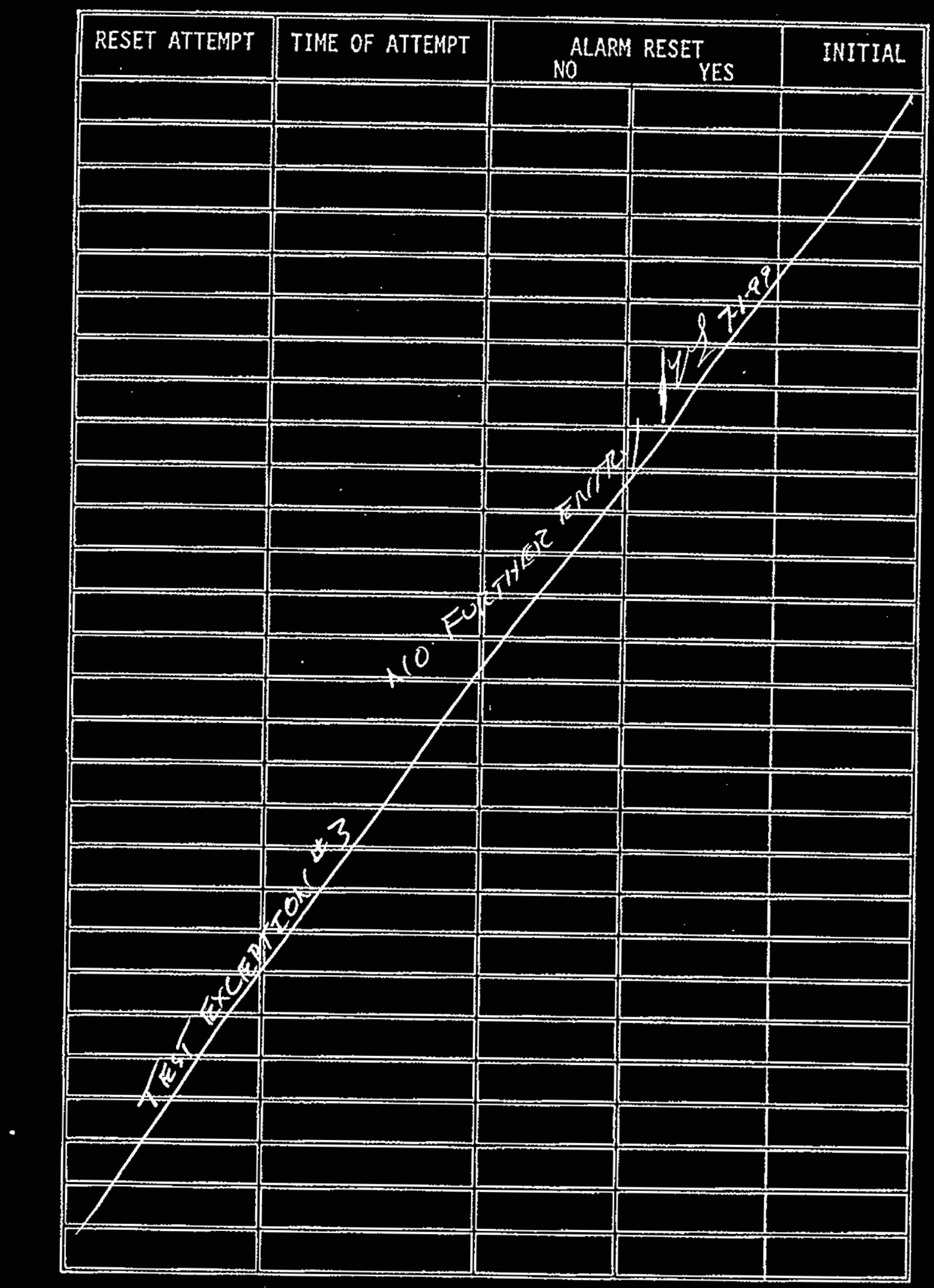

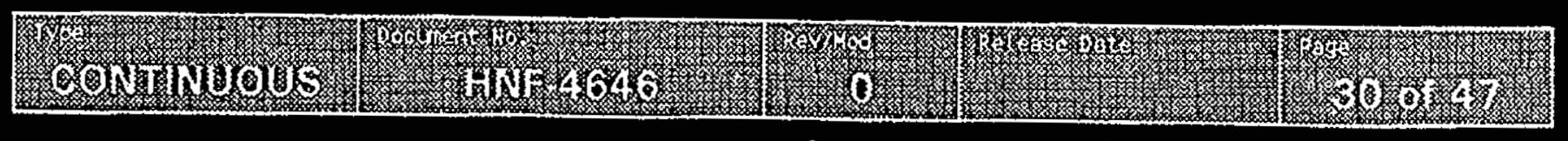

$$
38 \text { A-34 ReOd }
$$




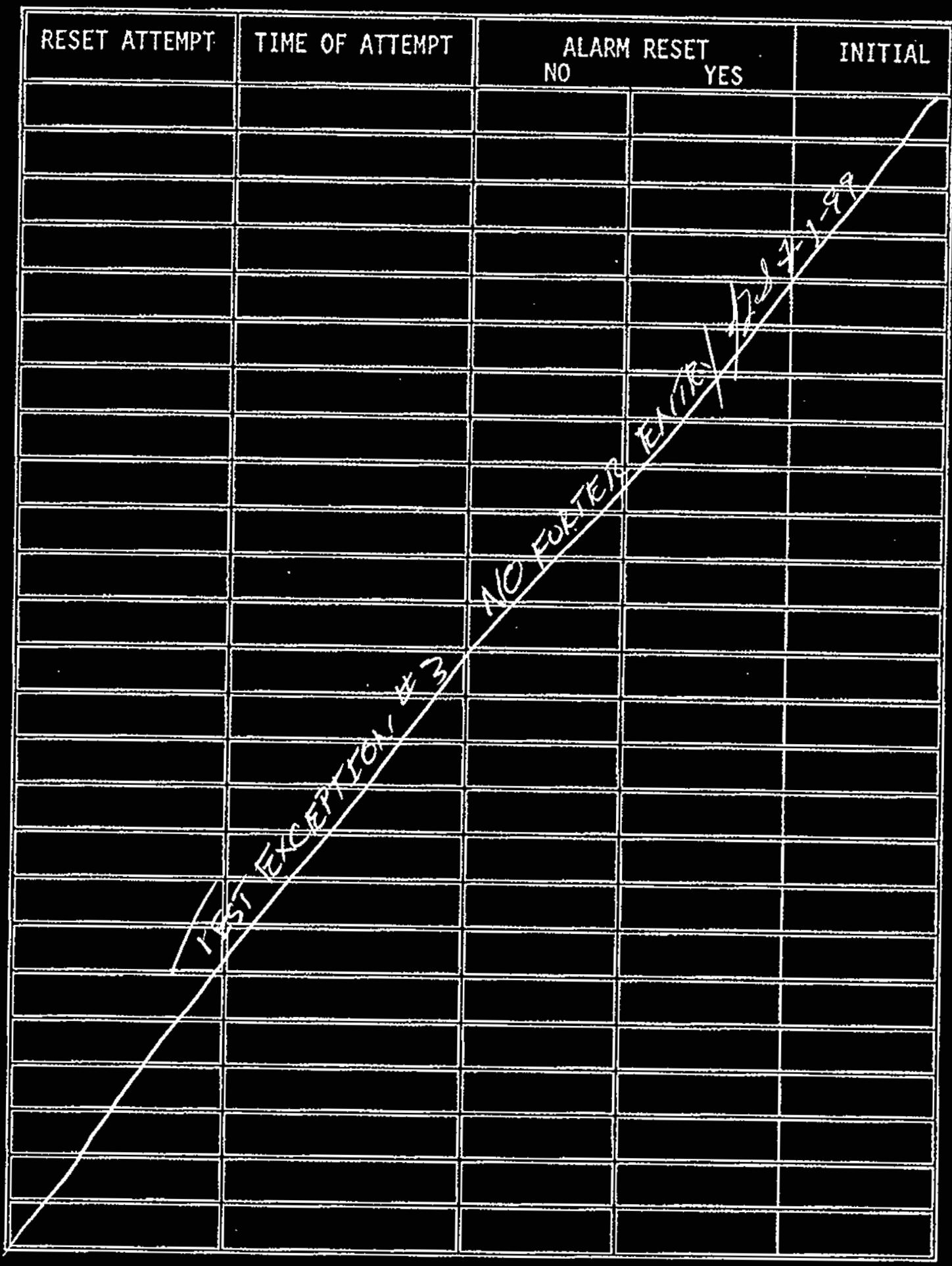

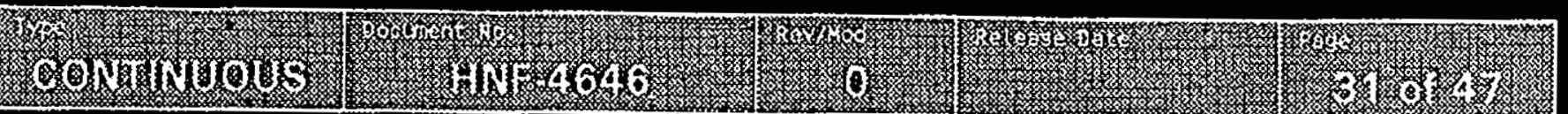

$$
39 \text { A-35 }{ }_{\text {Rwo }}^{1+N F-4647}
$$




\section{5,6 BN LEAK DETECTION RELAY LEAK SIMULATION TEST (Cont.)}

\section{6 .21 \\ IF ALARM RESETS prior to the 24 hour limit THEN document on}

TEST EX 3 TEST EXCEPTION LOG AND GO TO step 5.6.24.

125.6.22 PLACE the low point drain assembiy in the OPEN or RETRACTED

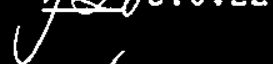

N/A5.6.23

fes 5.6 .24

res
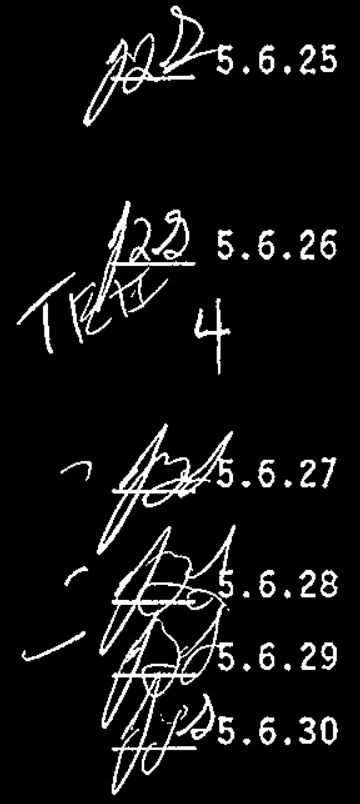

5.6 .31 position.

LOCATE AND ACTIVATE the "ALARM RESET" Switch ANB-HT-PB-23IC.

VERIFY the jocal strobe light alarm is NOT operating.

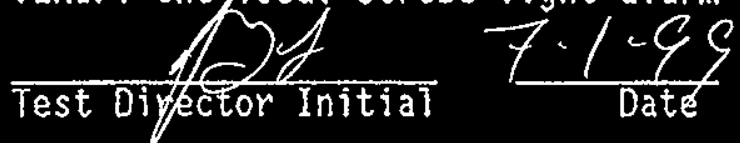

MEASURE AND RECORD the voltage BETWEEN Terminal TB-DC2-35 and TB-DC2-34 in Field Terminal BOX AN241-WT-TBX-101.

VOLTAGE 24.0

Futer vom

1055

VERIFy the voltage recorded in Step 5.6.25 at a nominal value of "gin Volts dc.

Test Diredtor Initial Date

ENSURE low point drain assembTy is in OPEN or RETRACTED position, AND FLUSH with 10 gal. RAW WATER.

REPEAT FLUSH with 11 ga?. RAW WATER.

REPEAT FLUSH with 12 gal. RAW WATER.

RESTORE the low point drain assembly to the CLOSED or UNRETRACTED position AFTER draining is complete.

VERIFY that Test 5.6 is COMPLETE by SIGNING below.
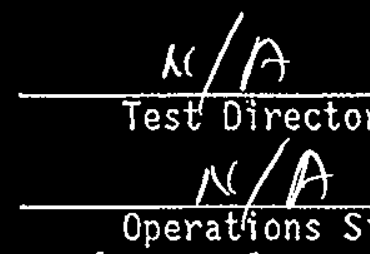

SEE TEST RXCEPTEON 3 RETEST

SEE TEST EXCETTION 4
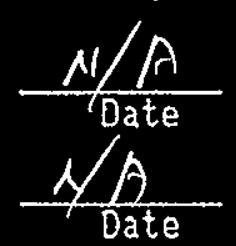


\subsection{MTL FAIL SAFE RELAY SWITCH TEST}

NOTE - The leak detection fail safe relay switch test identifies the functionality of the fail safe testing circuit. The test relay opens a probe circuit wire and activates the MrL Trip Amplifier.

ELECTRICAL TEST EQUIPMENT DATA TABLE

\begin{tabular}{|c|c|c|c|}
\hline TOOL NAME & 10. NUMBER & CAL DUE OATE & INITIAL/DATE \\
\hline FLUKE VOM & 0840 & 7.28 .99 & 286.27 .99 \\
\hline & & & \\
\hline & & & \\
\hline
\end{tabular}

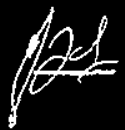

5.7 .1

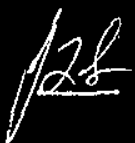

\section{7 .2}
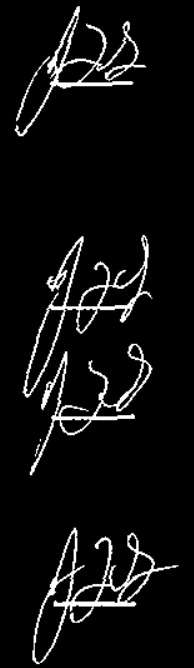

ENSURE that ANB-WT-LDSTA-231 disconnect switch ANB-4T-DS-231, reference orawing No, H-14-100989, SH. 2, is in the CLOSED position or ON, AND TOCal strobe light alarm is DEACTIVATED.

ROTATE selector switch ANB-WT-SS-231 to the "FAIL RELAY TEST" position, THEN RELEASE allowing spring return to the "Operate" position.

5.7.3 VERIFY that the local strobe light alarm ANB-WT-LDA-231A, reference drawing No. H-14-100989, SH. 2, is activated.

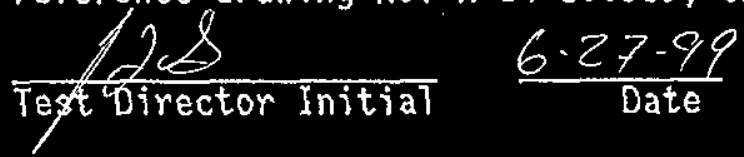

5.7.4 ROTATE AND HOLD selector switch ANB-WT-SS-23I to the "FAIL RELAY TEST" position.

5.7.5 MEASURE AND RECORD the voltage BETWEEN Termina? TB-DC2-35 and TB-DC2-36 in Field Terminal Box AN241-KT-TBX-101.

VOLTAGE 0.0

5.7.6 VERIFY the voltage recorded in Step 5.7.5 is at a nominal value of "O" Volts dc.

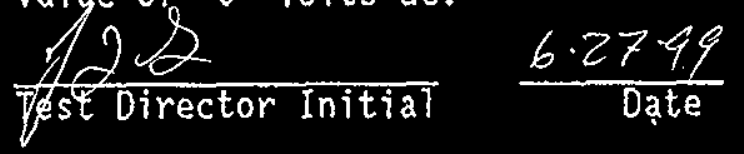




\subsection{MTL FAIL SAFE RELAY SWITCH TEST (Cont.)}

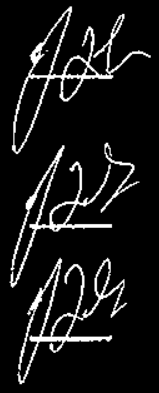

\section{7 .7}

RELEASE selector switch ANB-WT-SS-231 from the "FAIL RELAY TEST" position. (Switch should return to "OPERATE" position).

5.7.8 LOCATE AND ACTIVATE the "ALARM RESET" Switch ANB-WT-PB-231C, reference drawing H-14-100989, SH. 2.

5.7.9 VERYFY the local strobe light alarm is NOT operating.

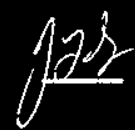

5.7 .10<smiles>c1cc2cc3cc(cc-3c1)C2</smiles>

Test Director Initia?

$\frac{6 \cdot 27 \cdot 99}{\text { Date }}$

$g \partial$

5.7.11 VERIFY the voltage recorded in Step 5.7.10 is at a nominal value of "24" Volts dc.

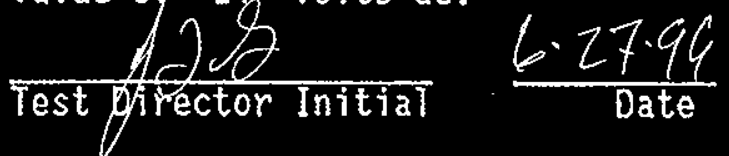

5.7.12 VERIFY that Test 5.7 is COMPLETE by SIGNING below.

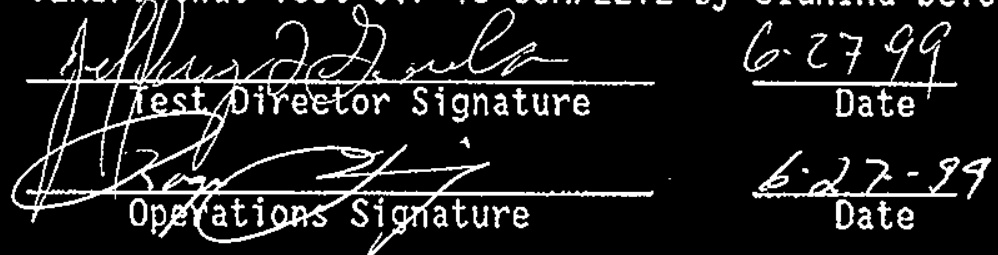

MEASURE AND RECORD the voltage BETWEEN Terminal TB-DC2-35 and. TB-DC2-36 in Field Terminal BOX AN241-WT-TBX-101.

VOLTAGE 24.02 


\subsection{MTL FAIL SAFE RELAY SIMULATION TEST}

NOTE - The MTL fail safe relay simulation test verifies the systems ability to a 7 arm in the event of the continuously monitored probe circuit is disconnected or damaged. This test will be accomplished by removing one of the plugs in the probe circuit.

\section{ELECTRICAL TEST EQUIPMENT DATA TABLE}

\begin{tabular}{|l|l|l|l|}
\hline TOOL NAME & ID. NUMBER & CAL DUE DATE & INITIAL/DATE \\
\hline FLUK VIOM & 1055 & 7.31 .99 & 286.27 .99 \\
\hline$M / A$ & & & \\
\hline$N / A$ & & & \\
\hline
\end{tabular}

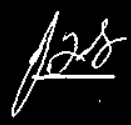

5.8 .1

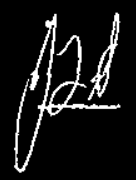

Iff

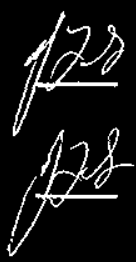

5.8 .4

\section{8 .3}

5.8 .6
ENSURE that ANB-WT-LDSTA-231 disconnect switch $A N B-W T-D S-231$, reference drawing No. H-14-100989, SH. 2, is in the CLOSED or ON position, AND JOCal strobe fight alarm is DEACTIVATED.

5.8.2 LOCATE AND REWOVE one end of cord set \#CS1 BETWEEN terminal box ANB-WT-TBX-W314-13P and terminal box ANB-WT-TBX-4314-13, reference drawing No. H-14-100989, SH. 2.

VERIFY that the local strobe light a a arm ANB-WT-LDA-231A, reference drawing No. $H-14-100989$, SH. 2 , is activated.

$\frac{128}{\text { Test pirector Initial }} \frac{6.27 .99}{\text { Date }}$

LOCATE AND ACTIVATE the "ALARM RESET" Switch

ANB-WT-PB-23IC, reference drawing No. H-14-100989, SH. 2.

5.8.5 VERIFY the local strobe light alarm remains operational.
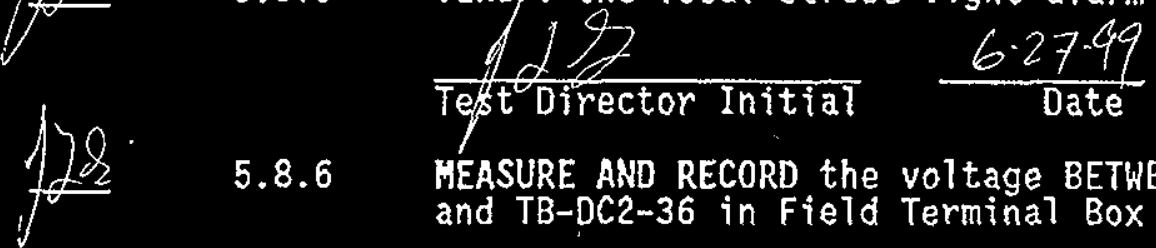

WEASURE AND RECORD the voltage BETWEEN Terminal TB-DC2-35 and TB-DC2-36 in Field Terminal BOX AN241-WT-TBX-101.

VOLTAGE $\quad 0.03$ 
5.8 MTL FAIL SAFE RELAY SIMULATION TEST (Cont.)

120

5.8.7 VERIFY the voltage recorded in Step 5.8.6 is at a nomina? value of "O" Vorts dc.

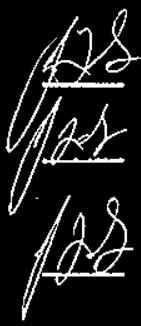

5.8.8 PLUG in the cord and removed in step 5.8.2.

5.8.9 LOCATE ANO ACTIVATE the "ALARM RESET" Switch ANB-WT-PB-231C, drawing reference No. H-14-100989, SH. 2.

5.8.10 VERIFY the local strobe light alarm is NOT operating. $\frac{27}{\text { Test Director Initial }} \frac{6.27 .99}{\text { Date }}$

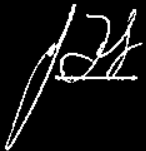

5.8.11 HEASURE AND RECORD the voltage BETWEEN Terminal TB-DC2-35 and TB-DC2-36 in Field Terminal Box AN241-WT-TBX-101. VOLTAGE 24.01

5.8.12 VERIFY the voltage recorded in Step 5.8.11 is at a nominal value of "24" Volts dc.

$\frac{627.99}{\text { Tegt Director Initial }}$

5.8.13 VERIFY the Test 5.8jis COMPLETE by SIGNING below.

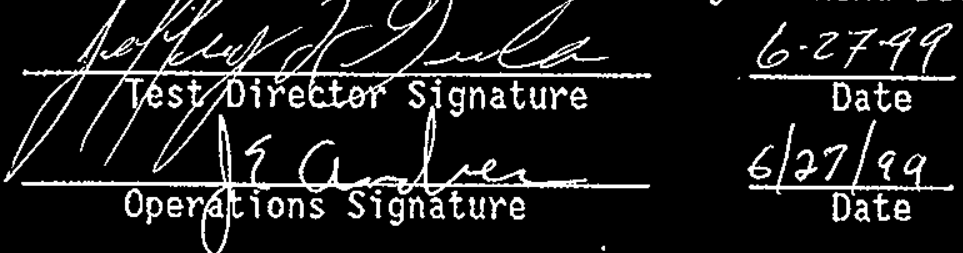




\subsection{REMOTE RESET TEST}

NOTE - The remote leak detection relay test is a function that allows the operator to reset the leak detection relay panel from the HMI. For the purposes of this Acceptance Test Procedure Section, a signal will be generated from Field Termina? Box AN241-WT-TBX-101, to the field device. An insulated temporary switch with jumper wires will be needed for this procedure.

\section{ELECTRICAL TEST EQUIPMENT DATA TABLE}

\begin{tabular}{|c|c|c|c|}
\hline TOOL NAME & ID. NUMBER & CAL DUE DATE & INITIAL/DATE \\
\hline FoKE VOM & 1055 & $7.31-99$ & $226.27-99$ \\
\hline & & & \\
\hline & & & \\
\hline
\end{tabular}
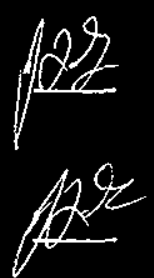

5.9 .2

5.9 .3

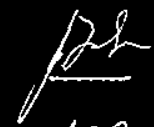

5.9 .4

5.9 .5

5.9 .6
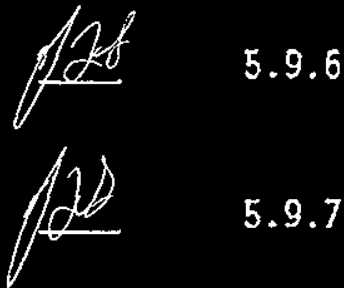

5.9 .7
ENSURE that ANB-WT-LDSTA-231 disconnect switch ANB-WT-DS-231, reference drawing No. H-14-100989, SH. 2, is in the OPEN or OFF position.

\section{WIRE a temporary switch, S-1, BETHEEN Termina1 TB-DC4-47} and TB-DC2-31 in Field Terminal BoX AN241-HT-TBX-101.

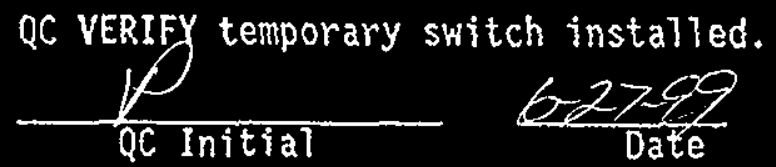

ENSURE the temporary switch is in the OPEN or OFF position.

ENSURE PaneT ANB-WT-LDSTA-231 DISCONNECT SWITCH

ANB-HT-DS-231 is in the CLOSED or ON POsition, AND local strobe light alarm is DEACTIVATED.

ROTATE selector switch ANB-WT-SS-231 to the "PROBE TEST" position, THEN RELEASE al lowing spring return to the

"Operate" position).

VERYFY that the local strobe light alarm ANB-WT-LDA-231A, reference drawing No. H-14-100989, SH. 2, is activated.

$\frac{2 \&}{\text { Tesp Director Initial }} \frac{6-27-99}{\text { Date }}$ 


\subsection{REMOTE RESET TEST (Cont.)}

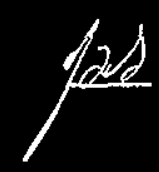

$N / A$

$N / A$

$N / A$

$\Delta / A$

$N / n$

(a)

$N / A$

5.9.8 MEASURE AND RECORO the VOT tage BETHEEN Termina]

TEST EXCEPTEON TB-DC2-35 and TB-DC2-31 in Field Terminat BOX

If AN241-WT-TBX-101.

VOLTAGE

5.9.9 VERIFY the yoltage recorded in Step 5.9.8 is at a nominal value of "24" Volts dc.

$\frac{N / A}{\text { Test Director Initial }}$

Date

5.9.10 Momentarily CLOSE THEN OPEN the temporary switch, BETWEEN Terminal TB-DC4-47 and TB-DC2-31 in Field Terminal BOX AN241-WT-TBX-101, installed in Step 5.9.2.

5.9.11 VERIFY that the local strobe light a] arm ANB-WT-LDA-231A, reference drawing No. H-14-100989, SH. 2, is NOT operational.

$\frac{N / A}{\text { Test Director Initial }}$

5.9.12 EHSURE Panel ANB-WT-LDSTA-231 DISCONNECT SHITCH ANB-HT-DS-231 is in the OPEN or OFF POsition.

5.9.13 REMOVE the temporary switch instailed BETWEEN TB-DC2-31 and $T B-D C 4-47$.

5.9.14 QC VERIFY temporary switch removed.

$\frac{N / A}{Q C \text { Initial }}$ Date

5.9.15 VERIFY that Test 5.9 is COMPLETE by SIGNING beTow.

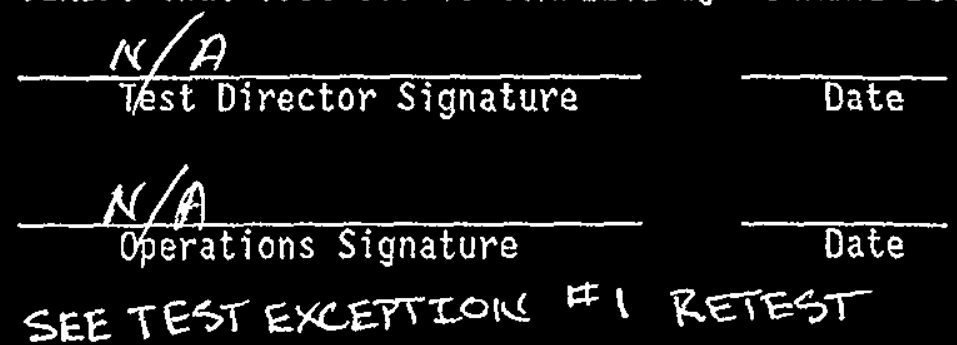

SEE TEST EXCEPTION \#I RETEST 


\subsection{REMOTE TRIP AMPLIFIERIVOLTAGE RELAY TEST}

NOTE - The remote leak detection relay test is a function that allows the operator to test the trip amplifjerlvoltage relay from the HMI display. For the purposes of this Acceptance Test Procedure Section, a signal witl be generated from Field Terminal Box AN241-WT-TBX-101. An insulated temporary switch with jumper wires will be needed for this procedure.

ELECTRICAL TEST EQUIPMENT DATA TABLE

\begin{tabular}{|l|l|l|l|}
\hline TOOL NAME & ID. NUMBER & CAL DUE DATE & INITIAL/DATE \\
\hline FLUKE 110M & 0840 & $7-28-96$ & $286-30.99$ \\
\hline & & & $:$ \\
\hline & & & \\
\hline
\end{tabular}

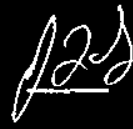

5.10 .1
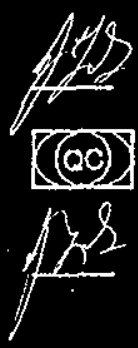

Nof

5.10 .4

5.10 .5

5.10 .6
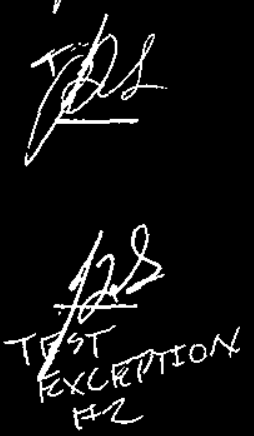

ENSURE that ANB-WT-LDSTA-23I disconnect switch

ANB-WT-OS-231, reference drawing No. H-14-100989, SH. 2 , is in the OPEN or OFF position.

5.10.2 WIRE a temporary switch, S-1, BETWEEN Terminal TB-DC4-47 and TB-DC2-33 in Field Termina1 Box AN241-WT-TBX-101.

5.10.3 QC VERKYY temporary switch installed.

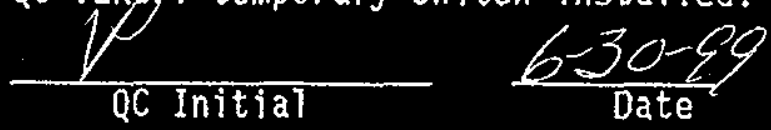

ENSURE the temporary switch is in the OPEN or OFF position.

\section{ENSURE PaneT ANB-WT-LDSTA-231 DISCONNECT SWITCH}

ANB-WT-DS-231 is in the CLOSED or ON POSition AND local strobe light alarm is DEACTIVATED.

MEASURE AND RECORD the voltage BETWEEN Terminal TB-DC4-47 and $T B-D C 2-33$ in Field TerminaT BOX AN241-WT-TBX-101.

VOLTAGE 22.19

5.10.7 VERIFY the voltage recorded in Step 5.10.6 is at a nomina? value of " 24 " Volts

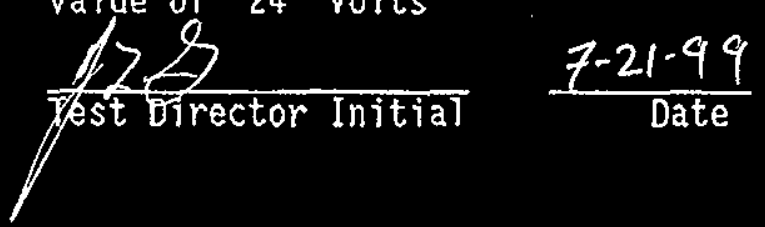




\subsection{REMOTE TRIP AMPLIFIER / VOLTAGE RELAY TEST (Cont.)}

T2h 5.10 .8 Momentarily CLOSE THEN OPEN the temporary switch BETWEEN
Terminal TB-DC4-47 and TB-DC2-33 in Field Termina] BOX

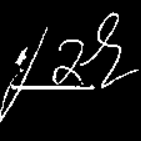

5.10 .9 AN241-WT-TBX-101.

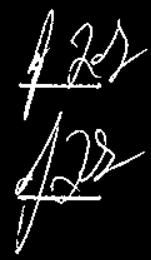

5.10 .10

VERIFY that the local strobe light alarm ANB-HT-LDA-23IA, referenge drawing No. H-14-100989, SH. 2 , is operationa?. $\frac{2 \alpha}{\text { Test Pirector Initial }} \frac{6-30-99}{\text { Date }}$

LOCATE AND ACTIVATE the "ALARM RESET" Switch

ANB-WT-PB-23IC, reference drawing No. H-14-100989, SH. 2.

5.10.11 VERIFY that the local strobe Tight alarm ANB-WT-LDA-231A is NOT operational.

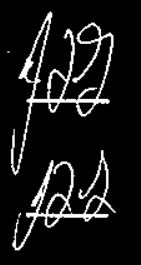

5.10.12 ENSURE Panel ANB-WT-LDSTA-231 DISCONNECT SWITCH is in the

$\frac{17 \text { f }}{\text { Test prector Initiat }} \frac{6-30-99}{\text { Date }}$ OPEN or OFF POSition.

5.10.13 REMOVE the temporary switch, S-1, BETWEEN Terminal JB-DC4-47 and TB-DC2-33 in Field Terminal Box

(a)) 24

5.10.14 QC VERIFY temporary switch removed.

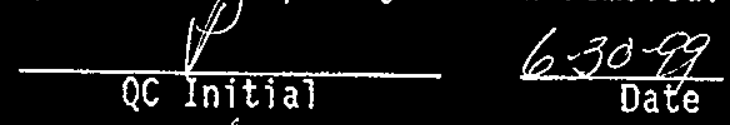

5.10.15 VERIEY that Test 5.10 is COMPLETE by SIGNING beTow.

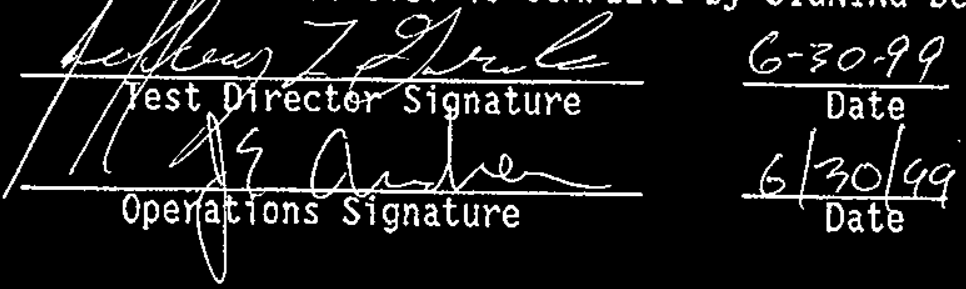




\subsection{REMOTE LEAK DETECTION RELAY TEST (Pit leak detection probe test)}

NOTE - The remote leak detection relay test is a function that allows the operator to test the leak detection relay from the HMI display. For the purposes of this Acceptance Test Procedure Section, a signal will be generated from Field Terminal Box AN241-WT-TBX-101. An insulated temporary switch with jumper wires will be needed for this procedure.

ELECTRICAL TEST EQUIPMENT DATA TABLE

\begin{tabular}{|c|c|c|c|}
\hline TOOL NAME & ID. NUMBER & CAL DUE DATE & INITIAL/DATE \\
\hline FLUKK VOM & 0840 & $7-28.99$ & 22.6 .30 .99 \\
\hline & & & \\
\hline & & & \\
\hline
\end{tabular}

5.11.1 ENSURE that ANB-WT-LDSTA-231 disconnect switch ANB-NT-DS-231, reference drawing No. H-14-100989, SH. 2, is in the OPEN or OFF position. AND Tocal strobe light alarm is DEACTIVATED.

5.11.2 HIRE a temporary switch, S-1, BETWEEN Terminal TB-DC4-47 and TBDC2-32 in Field Terminal BOX AN241-WT-TBX-101.

5.11.3 QC VERIFY temporary switch installed.
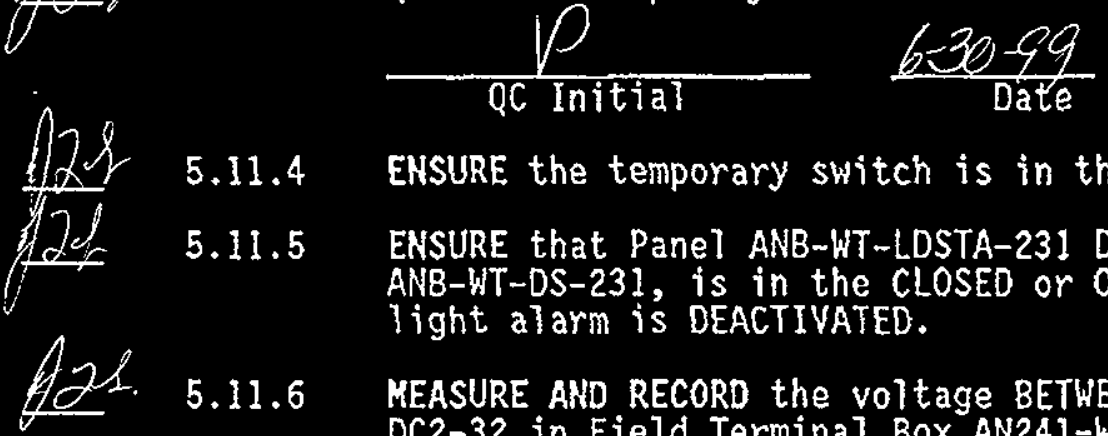

5.11.4 ENSURE the temporary switch is in the OPEN or OFF position.

5.11.5 ENSURE that Panel ANB-WT-LDSTA-231 Disconnect Switch ANB-WT-DS-231, is in the CLOSED or ON position, AND Tocal strobe light alarm is DEACTIVATED.

5.11.6 MEASURE AND RECORD the voltage BETWEEN Terminat TB-DC4-47 and TBDC2-32 in Field Terminal BOX AN241-WT-TBX-101.

VOLTAGE $22 \cdot 17$

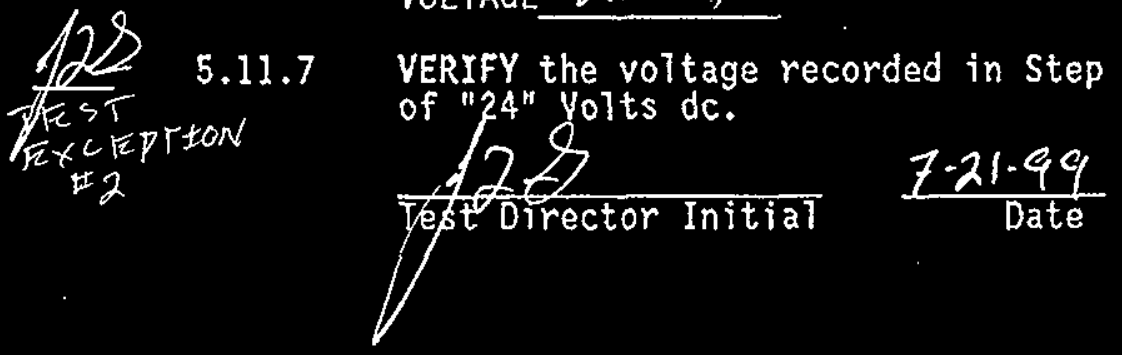




\subsection{REMOTE LEAK DETECTION RELAY TEST (Cont.)} (Pit leak detection probe test)

22

5.11.8 Momentarily CLOSE THEN OPEN the temporary switch BETWEEN Terminal TB-DC4-47 and TB-DC2-32 in Fie?d Terminal Box AN241-NT-TBX-101.

5.11.9 VERIFY that the local strobe light alarm ANB-NT-LDA-231A, reference drawing $\mathrm{No}$. H-14-100989, SH. 2, is operational.

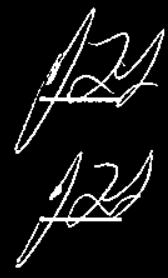

5.11 .10 $\frac{20}{\text { Testpirector Initial } \frac{6-30-99}{\text { Date }}}$

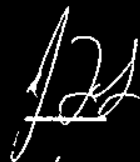

5.11.11 VERIFY that the local strobe light alarm ANB-WT-LDA-231A is NOT LOCATE AND ACTIVATE the "ALARM RESET" Switc
reference drawing No. H-14-100989, SH. 2. operational.

$$
\text { Test Difrector Initial } \frac{6-30-99}{\text { Date }}
$$

5.11.12 ENSURE Pane1 ANB-WT-LOSTA-231 DISCONNECT SWITCH ANB-HT-DS-23I is in the OPEN or OFF Position.

5.11.13 REMOVE the temporary switch BETWEEN Terminal TB-DC4-47 and TB-DC2-32 in Field Terminal Box AN241-WT-TBX-101.

5.11.14 QC VERIFY temporary switch removed.

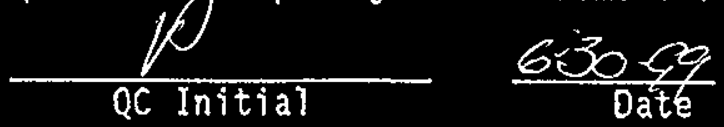

5.11.15 . VERIFY/thay/Test 5.11 is COMPLETE by SIGNING below.

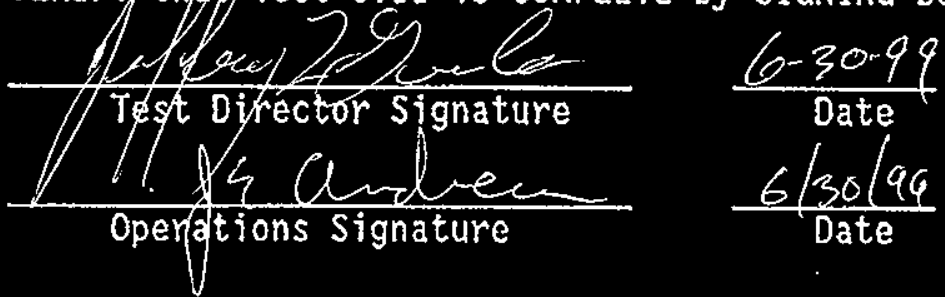




\section{ATP PERFORMANCE LOG}

This page may be reproduced as necessary. Page 1 of 2

\begin{tabular}{|c|c|c|}
\hline 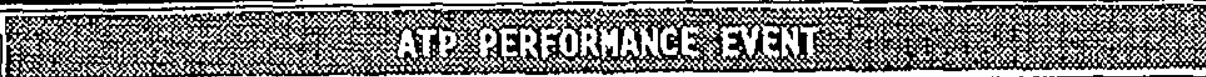 & (1) & (y) \\
\hline PRETEST BRIEFENG HELDIAN CRAFT LUNCH TOOOM & $6-26-9$ & \\
\hline $\operatorname{ICS}, 2 E-99.01329$. & & \\
\hline COMPLFTED SECTION 4.3 \& 5.1 & 6.26 & \\
\hline PTB JCS.2E-99.01329. COMPLFTFD 5.15 .2 & $6 \cdot 27$ & \\
\hline $5.3,5.4,5.5,5.7,5.8$ RELAY $t 2310$ FAILED & & \\
\hline DORENG 5.9 TF-1 MRITTEN. DISCONKET OPEK & & \\
\hline STOPPED TESTING & & \\
\hline NCR.W-314CFDKW (2) HAS TESTING ONS KOLD. & 6.28 .49 & \\
\hline NO TESTING & & \\
\hline PIB. HELD IN CRAFT LUNCH ROOW ICS & & \\
\hline CONDITIONS DISCUSSED. & & \\
\hline RETESTED STEPS, $3.4,5.7$ AMD RFPERFORMFD & $6-30.99$ & \\
\hline STE 2.5 .9 & & \\
\hline TEST EXCFPTION 8 S FOR SECTION $5.10,5.11$ & $6-30.99$ & \\
\hline NOMINAL 24 VOLTS NOT DFFINED ZZVOLTS & & \\
\hline OBSERVED. CONTINUE TESTING COMPLFTE SECTIOX & & \\
\hline PTB FOR STEP 5.6 HFLP IN FIELD & $6-30.99$ & \\
\hline FOR WALK THRONGH. THFN STARTEDD 5.6 & & $42 \pi$ \\
\hline SHIFT TO \& PTB HFLD IN FIELD & $6-30-99$ & \\
\hline TEST IR PROQRESS & & 4 \\
\hline$N-A$ & U & \\
\hline
\end{tabular}




\section{ATP PERFORMANCE LOG}

This page may be reproduced as necessary. Page 2 of 2

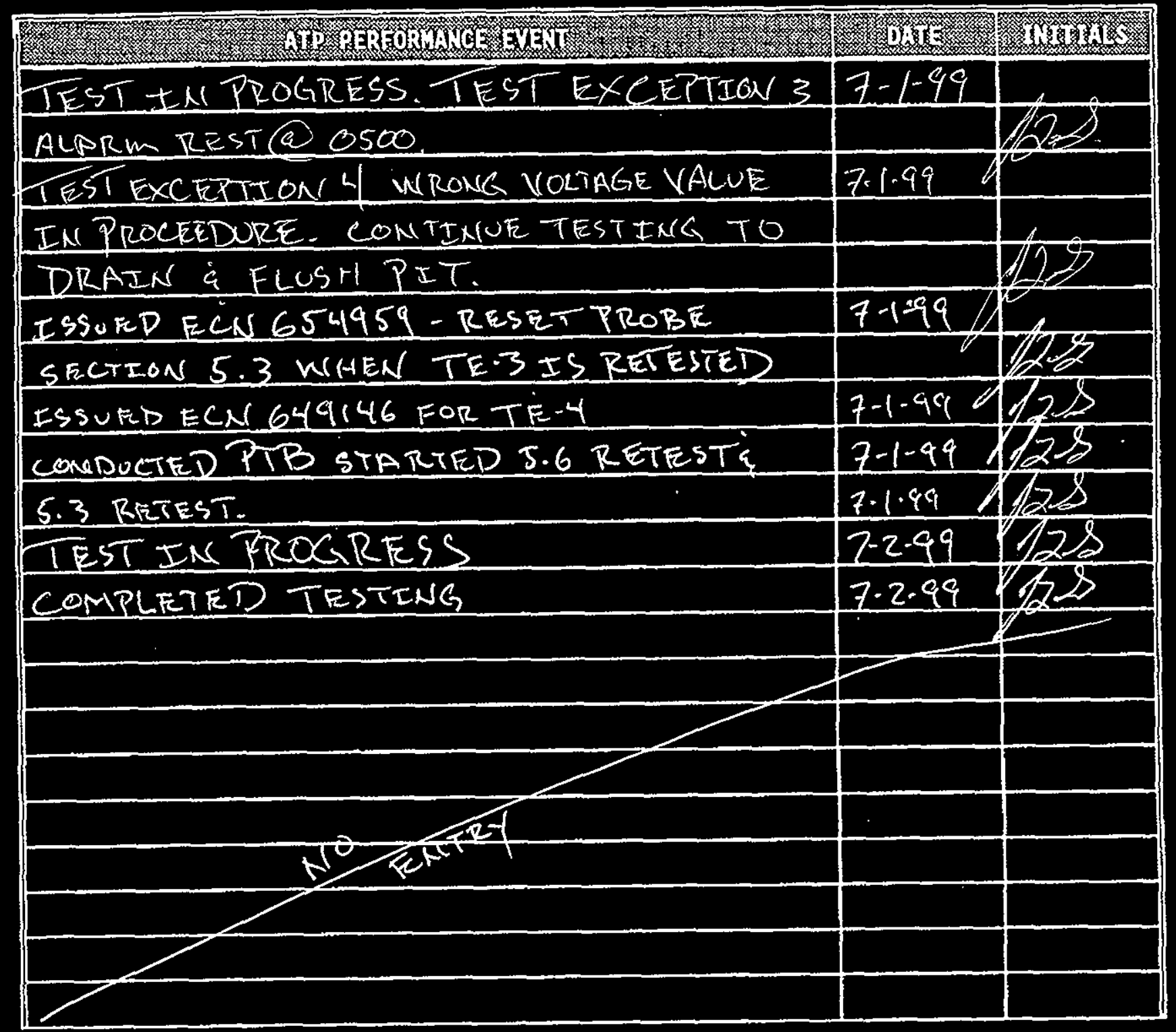

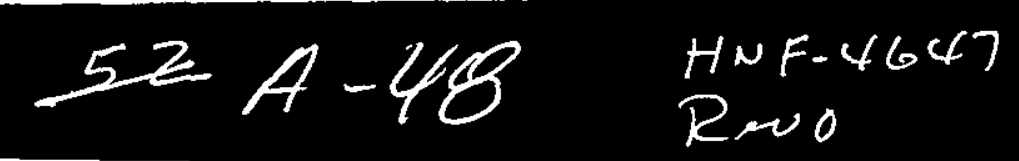




\section{ATP EXCEPTION LOG}

This page may be reproduced as necessary. Page $i$

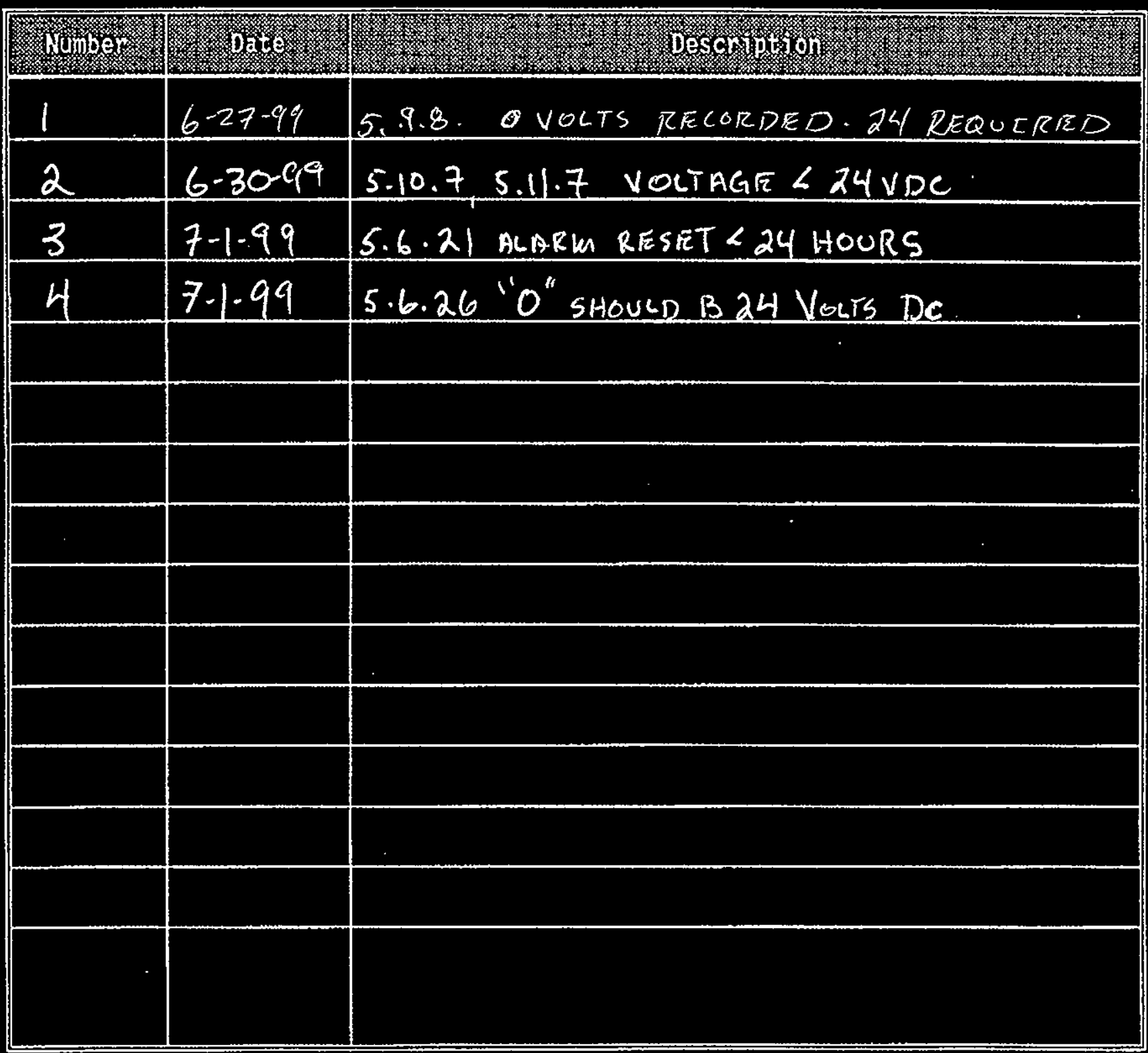




\section{ATP EXCEPTION RECORD}

This page may be reproduced as necessary.

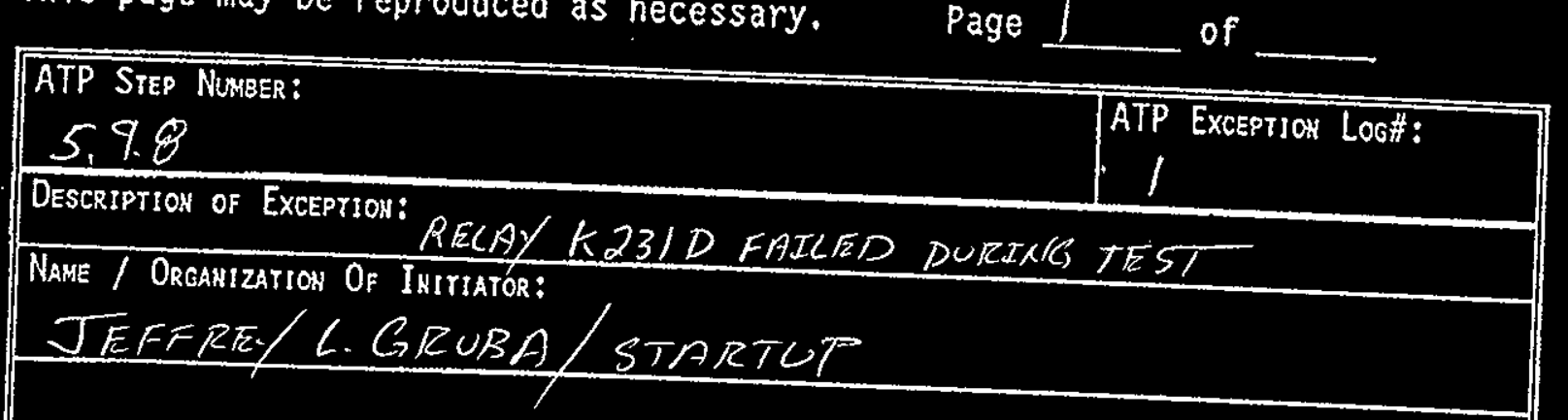

Resolution of EXEEPTION: NCR W-314 (FDNUT12) REQUTRFD RELA)

TO BE RFPLACED. RETEST SECTEON 5.9 P $5.4,5.7$
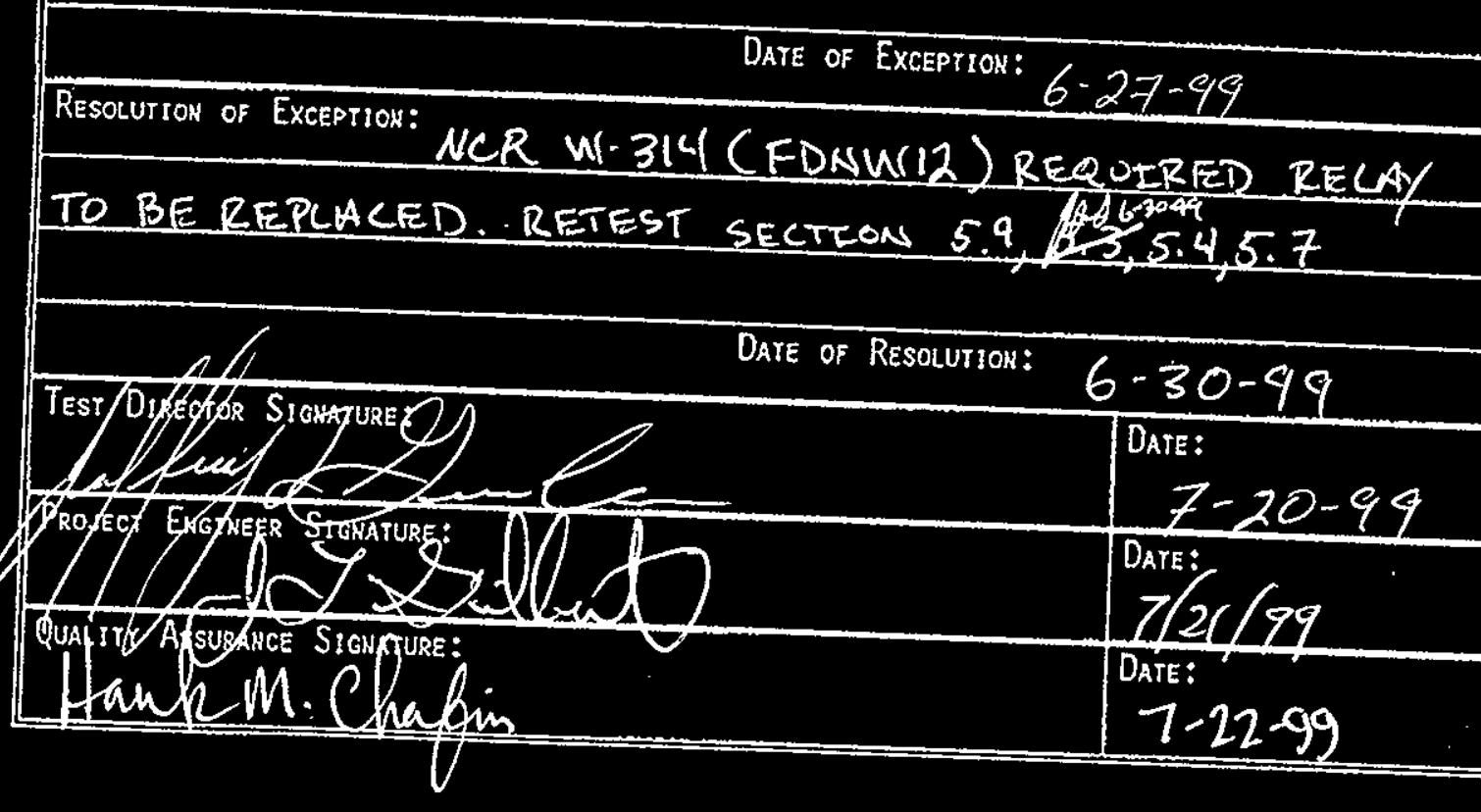

$$
\text { Date of Resolvijon: } 6-30-99
$$

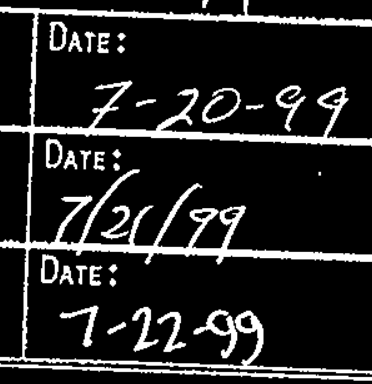


HNF-4646

Test Exception 1

Page 2 of

Planned Resolution

Initiate a Non-Conformance Report for relay K-231D describing the failure of the relay to latch. Restore the relay design function in accordance with engineering disposition.

Justification

The relay K-231D is a Safety Related component that requires engineering review and resolution.

Conclusion

Suspend testing 6-28-99 on ATP until NCR for the K-231D relay is resolved.

Resolution of Exception

NCR W-314 (FDNW12) was issued on 6-28-99 to document the condition. 


\section{NONCONFORMANCE REPORT

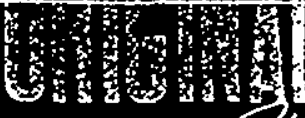

Project No.

U. $3 / 4$

W.o. No.

$12 / 3 / 4-4 C$

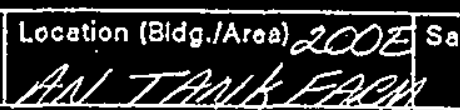

doss $60-292$

SC
SC

Page

1 of NCR No.

Job Titio

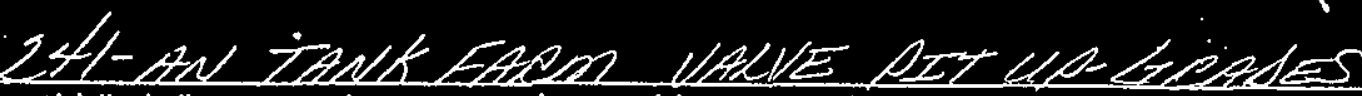

Requirement(s) (Including source document numbers, revision, paragraph, etc.)

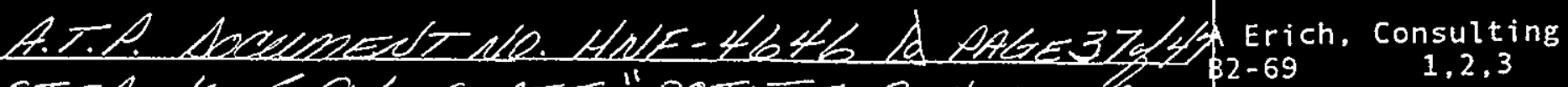

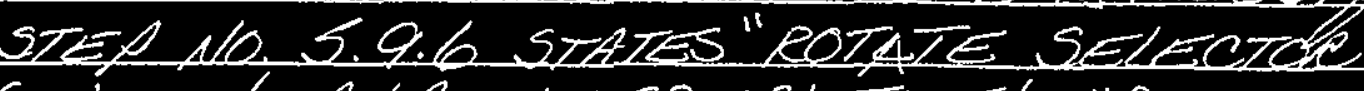

SULTRCA AN B-WT-SS-2.3L TO THE "PREBE

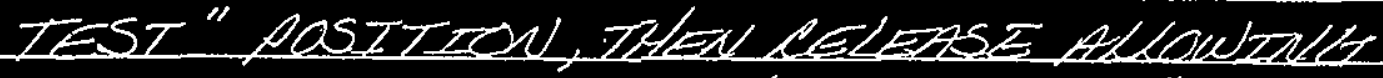

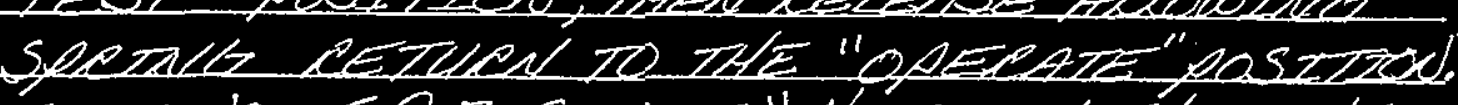

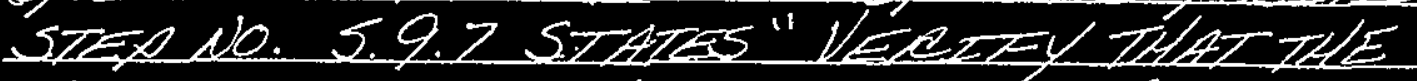

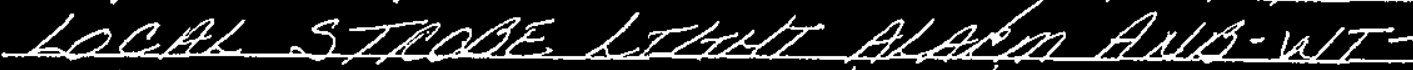

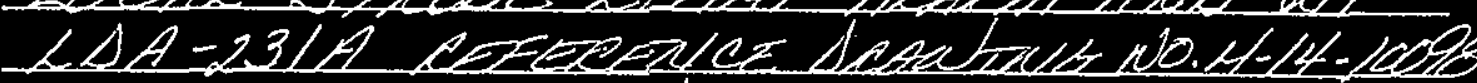
$54.2+25$ ACZZUATEX.

NHC

L Gilbert R3-47

$1,2,3$

WW Leliefeld S0-09

L, 2,3

DL MCGrew R3-25

$1 ; 2,3$

MHC

R3-47

$1,2,3$

$55-13$

$1,2,3$

JL Homan

R3-25

Description of Nonconformance:

$1,2,3$

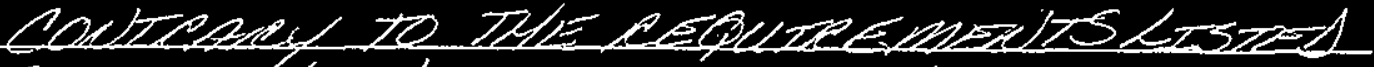

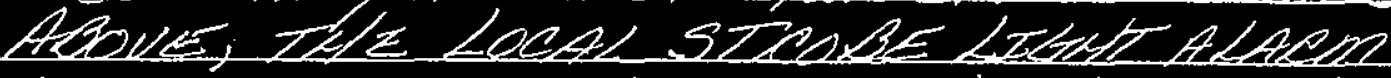

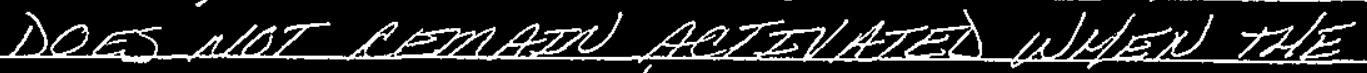

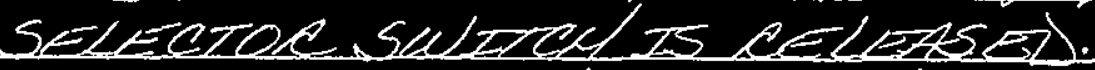
NOTE: THE 24VDC RELAY \#K-2.31 (AOTIER BLOOMFEZ MODEL \#KBPUSG)WILL LATCW

FDNW

AI Files

QC Files

1,3

CD

$E / Q A \& P C$

1,2

$1,2,3$

B4-68

HM Chafin R3-25

When LEEHTH TAPped. When the velay is latched the strobe light aloum will work poperly.

$1,2,3$

JP Bedell G3-12

$1,2,3$

$1,2,3$

Is Hammer

G3 - 12

$1,2,3$

WR Swift

1,3

BL Syverson G3-12

$1,2,3$

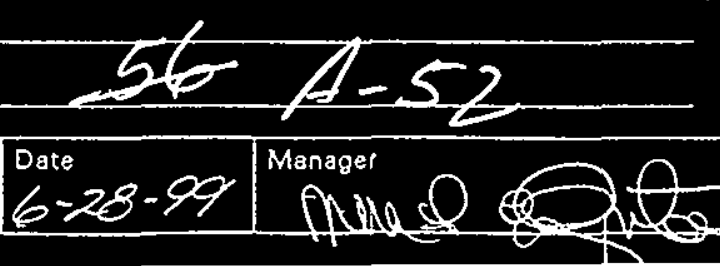

$$
\begin{gathered}
\text { HNF-4647 } \\
\text { RUO }
\end{gathered}
$$




\section{NONCONFORMANCE REPORT (continued)}

Disposition

$\square$ Uso-as-is" $\square$ Roject $\square$ Repaip* $\square$ Rework - Justification Required ASME Code Related $\square$ No $\square$ Yes 2 Zause Code (ASME Code Section

Disposition Instructions (generally not required for use-as-is and reject dispositions):

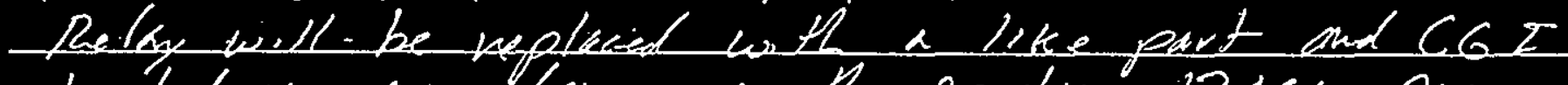

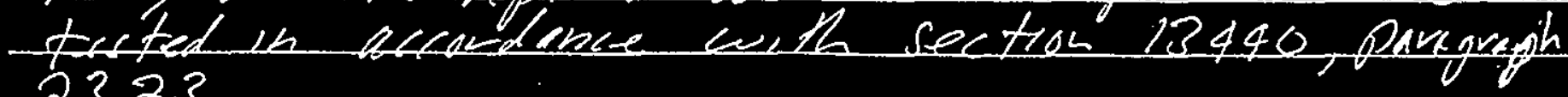
$23,2 . ?$

ECN (generally required for repair and use-as-is dispositions):
$\square$ Yos
No
If Yos, ECN No.

If no, provide explanation:

Disposition Justification (if applicable):

Approval/Concurrence:

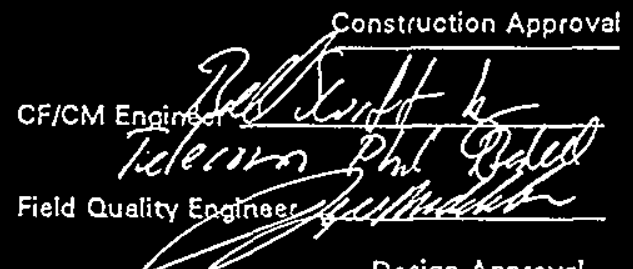

Design Engineer Design Approval
Date $6 / 29 / 99$ Dete $<-28-2 \sum$

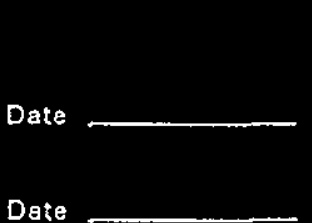

Date

Date

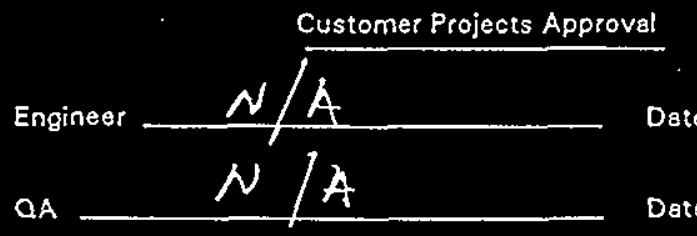

FDH $\frac{N / A}{N / A}$

Closure

$\square$ Disposition Completed as Directed

$\square$ other (Explain).

Date

Date

Dase

Date

Date 


\section{Belhaven Applied Technologies}

This letter certifies that the replacement of the socketed Potter $\&$ Brumfield latching relays will not void the ETL rating of electrical leak detection cabinets.

The relays are a like for like replacement of the same part number and will not affect the overall ETL certification.

Jeff Cadick

- S. Caseceto

QA Manager 


\section{ACCEPTANCE PLAN}

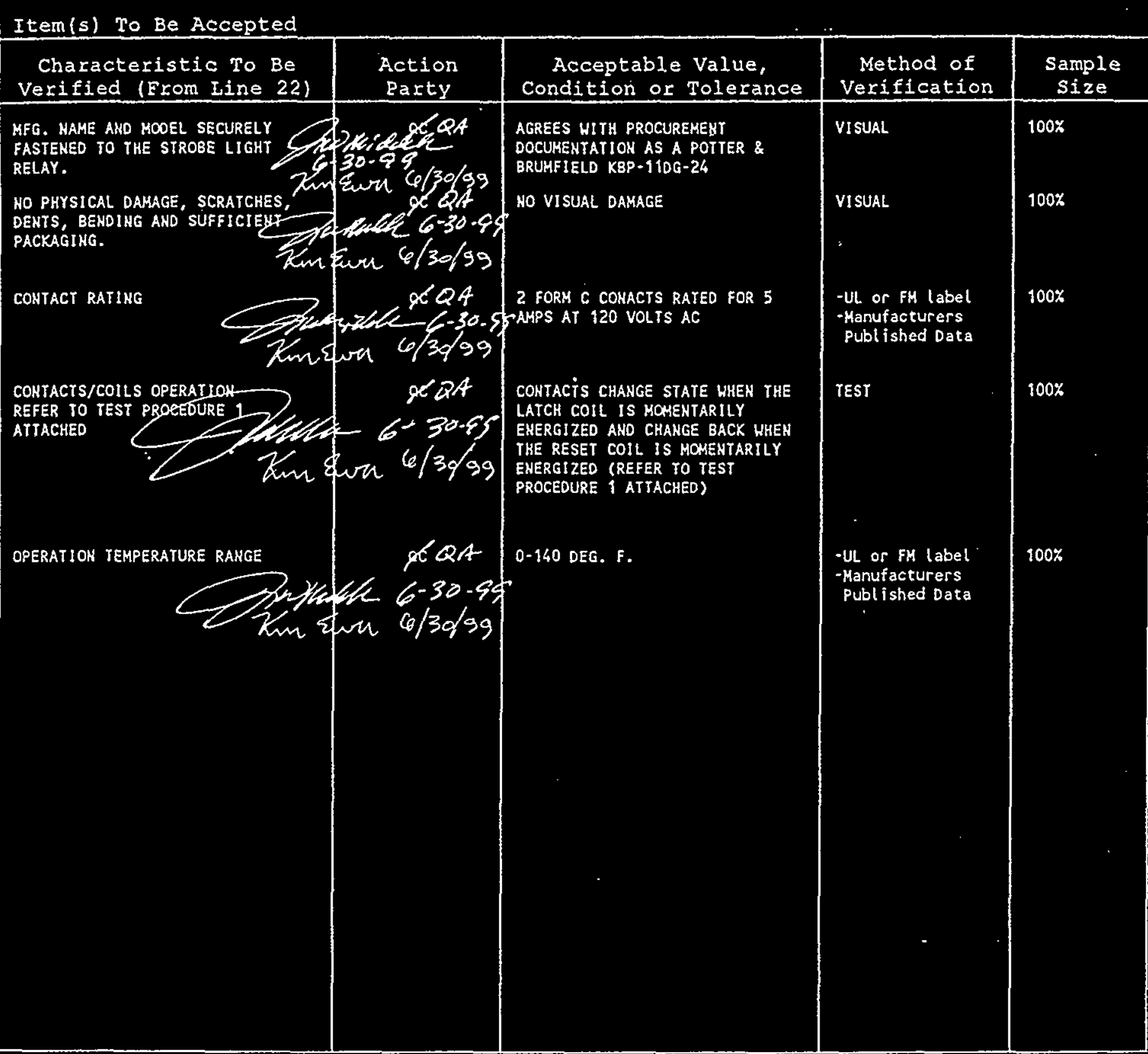

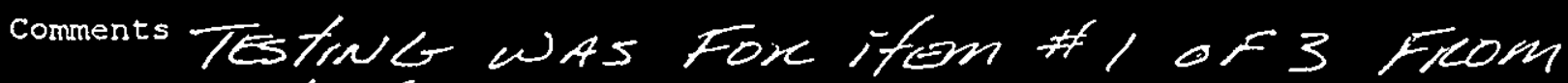
Lot \#9910

4 costlention $6-30.55$

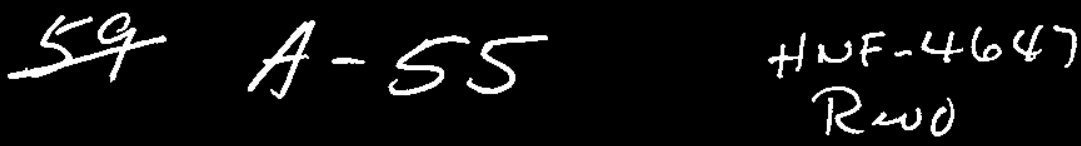




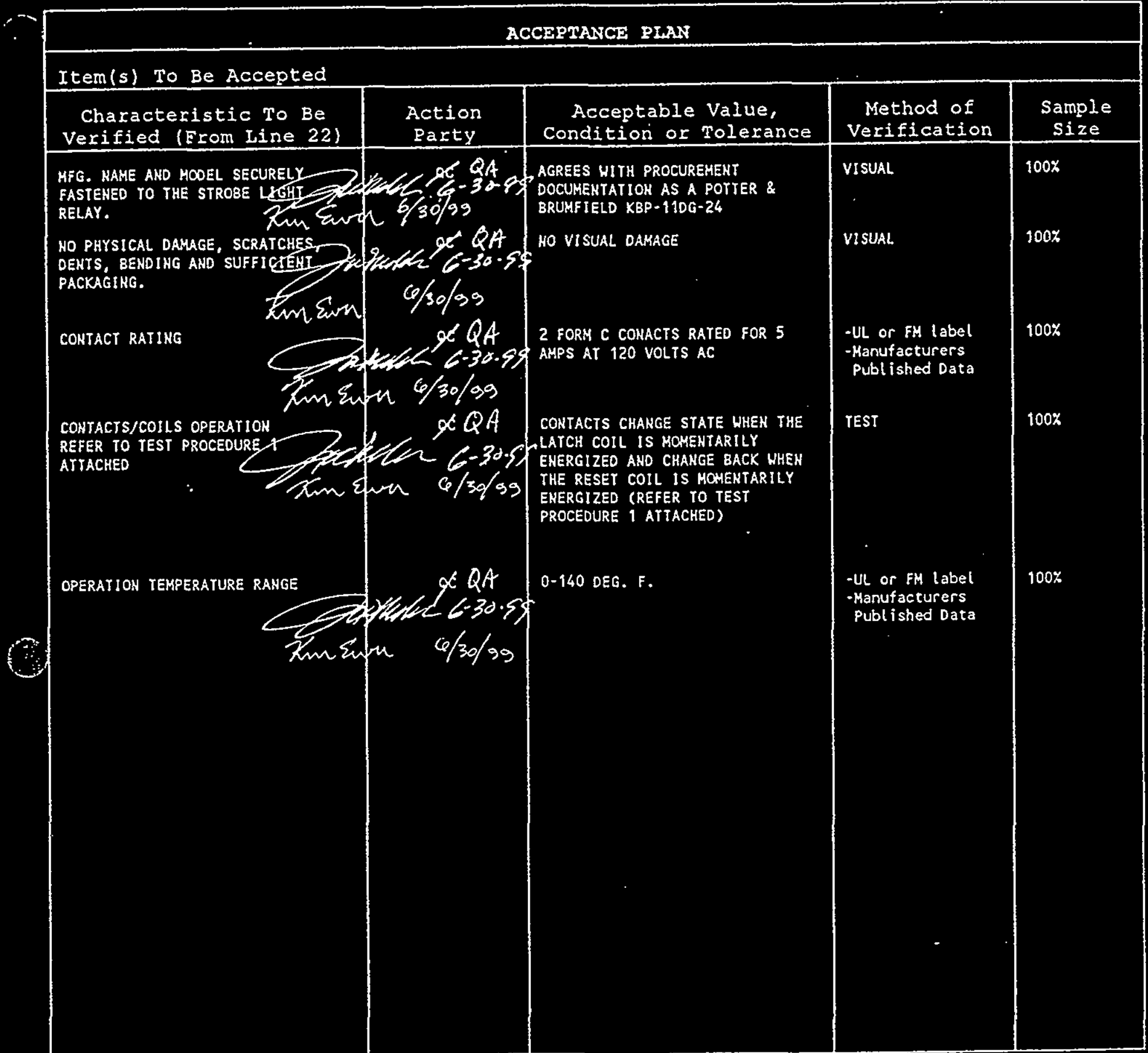

coments TESTIGWAS tor if W $\$ 2$ OF 3 FROM Lot $\$ 9910$

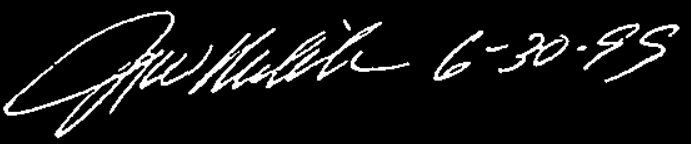




\section{ACCEPTANCE PLAN}

\section{Item (s) To Be Accepted}

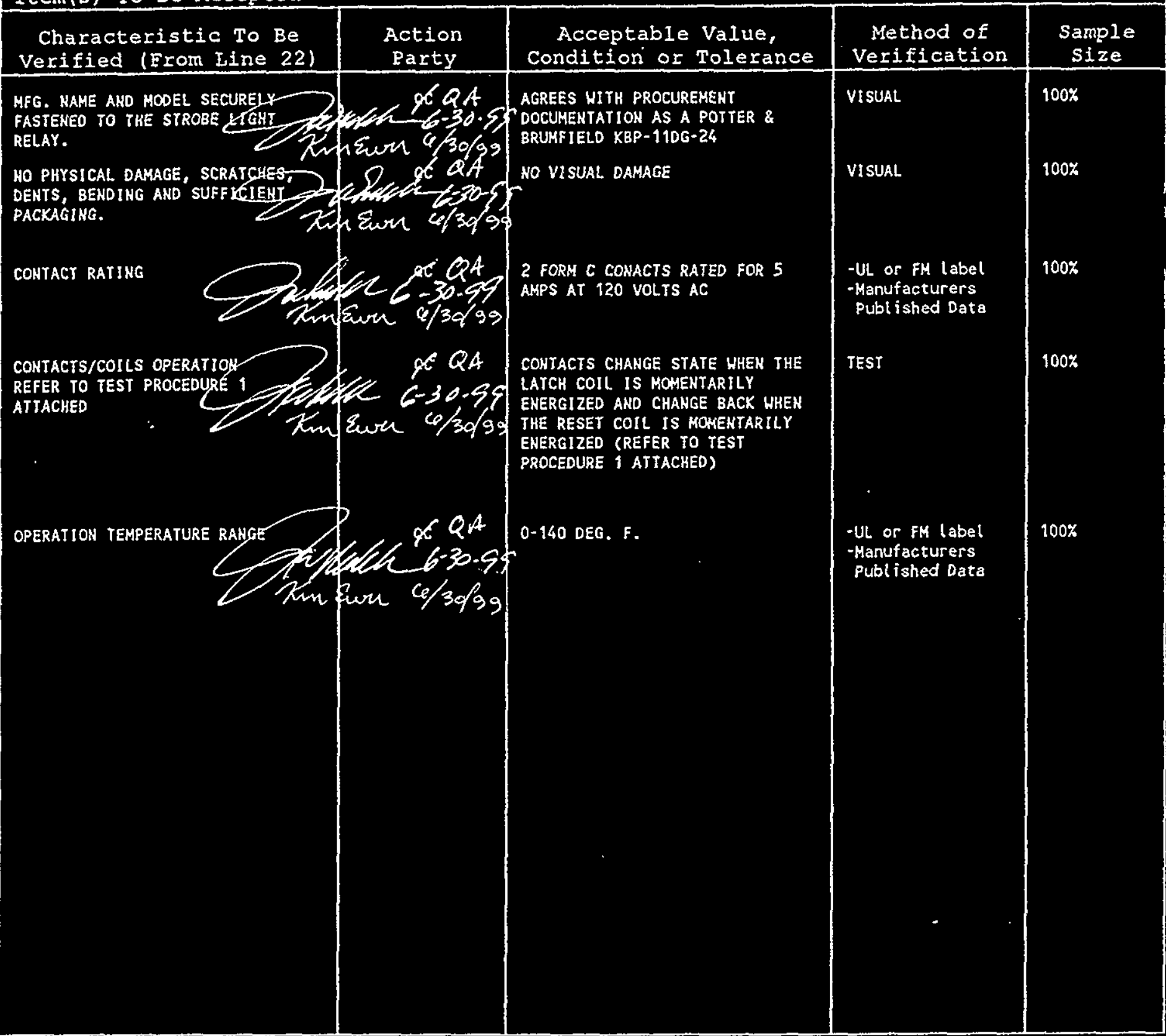

comments Testrug wos rov item 3 or 3 Fin?

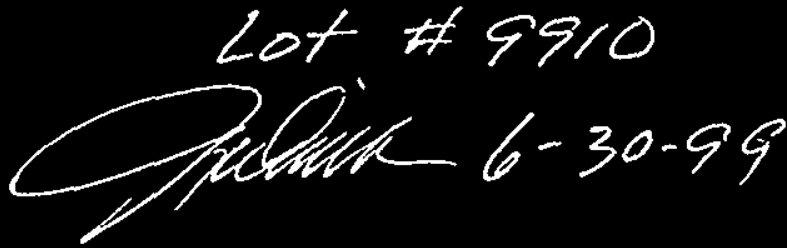




\section{TEST PROCEDURE 1}

Verify contacts change state when the latching coil has been momentarily energized and that the contacts return to original state when the reset coil is energized (refer to vendor supplied data for contact and coil terminal points and minimum coil pick-up voltage ratings).

- Verify the state of all contacts without the latch coil energized.

- Momentarily energize the $24 \mathrm{~V}$ dc latch coil.

- Verify all contacts change state.

Momentarily energize the $24 \mathrm{~V}$ dc reset coil.

Verify all contacts change state back to their original state. 


\subsection{REMOTE RESET TEST}

NOTE - The remote leak detection relay test is a function that allows the operator to reset the leak detection relay panel from the Hil. For the purposes of this Acceptance Test Procedure Section, a signal will be generated from field Terminal Box AN241-11T-TBX-101, to the field device. An insulated temporary switch with jumper wires will be needed for this procedure.

ELECTRICAL TEST EQUIPNENT DATA TABLE

\begin{tabular}{|l|l|l|l|}
\hline \hline TOOL NAME & ID. NUMBER & CAL DUE DATE & IMITIAL/DATE \\
\hline FLUTE V10m & 0840 & $7-28.99$ & 286.3099 \\
\hline & & & \\
\hline & & & \\
\hline
\end{tabular}

218

128

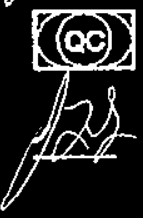

24

5.9 .4

5.9 .3

5.9 .2

$\frac{\text { QC VERIFY temporary sw }}{\text { QC Initial }}$ position.
ENSURE that ANB-NT-LDSTA-231 disconnect switch

ANB-WT-DS-231, reference drawing No. H-14-100989, SH. 2, is in the OPEN or OFF position.

WIRE a temporary switch, S-1, BETWEEN Terminal TB-DC4-47 and TB-DC2-31 in Field Terminal BoX AN241-NT-TBX-101.

EMSURE the temporary switch is in the OPEN or OFF

5.9.5 EXSURE Panel ANB-WT-LDSTA-231 DISCONECT SWITCH

ANB-WT-DS-231 is in the CLOSED or ON Position, AND local strobe light alarm is DEACTIVATED.

5.9.6 ROTATE selector switch ANB-WT-SS-231 to the "PROBE TEST" position, THEW RELEASE allowing spring return to the "Operate" position).

5.9.7 VERIFY that the local strobe light alarm ANB-NT-LDA-231A, refergnce drawing $N_{0}$. H-14-100989, SH. 2, is activated.

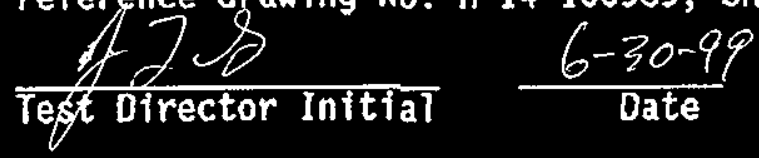

TE I RETEST

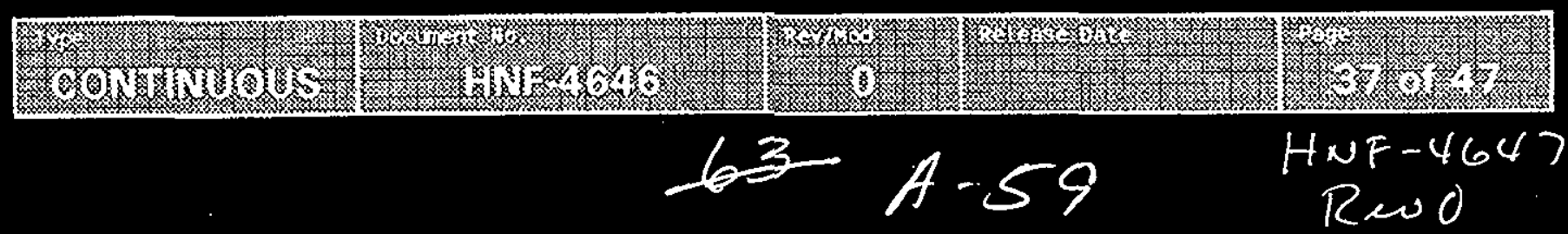




\subsection{REMOTE RESET TEST (Cont.)}

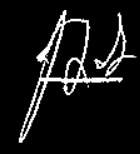

\section{9 .8}

MEASURE AND RECORO the voltage BETWEEN Termina]

$\mathrm{TB}-\mathrm{DC} 2-35$ and $\mathrm{TB}-\mathrm{DC} 2-31$ in Field Terminal BoX

AN241-WT-TBX-101.

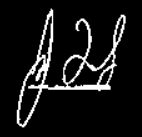

VOLTAGE $24.0 \%$

5.9.9 VERIFY the voltage recorded in Step 5.9 .8 is at a nominal value of "24" Volts dc.

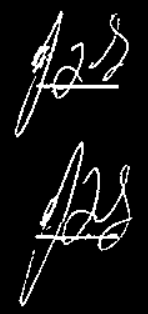

\section{9 .10}

Test virector Initial

$$
\frac{6-30.99}{\text { Date }}
$$

Momentarily CLOSE THEN OPEN the temporary switch, BETWEEN Terminal TB-DC4-47 and TB-DC2-31 in Field Terminal Box AN241-WT-TBX-101, installed in Step 5.9.2 .

5.9.11 VERIFY that the loca] strobe light alarm ANB-NT-LDA-231A, reference drawing No. H-14-100989, SH. 2, is NOT operationa1.
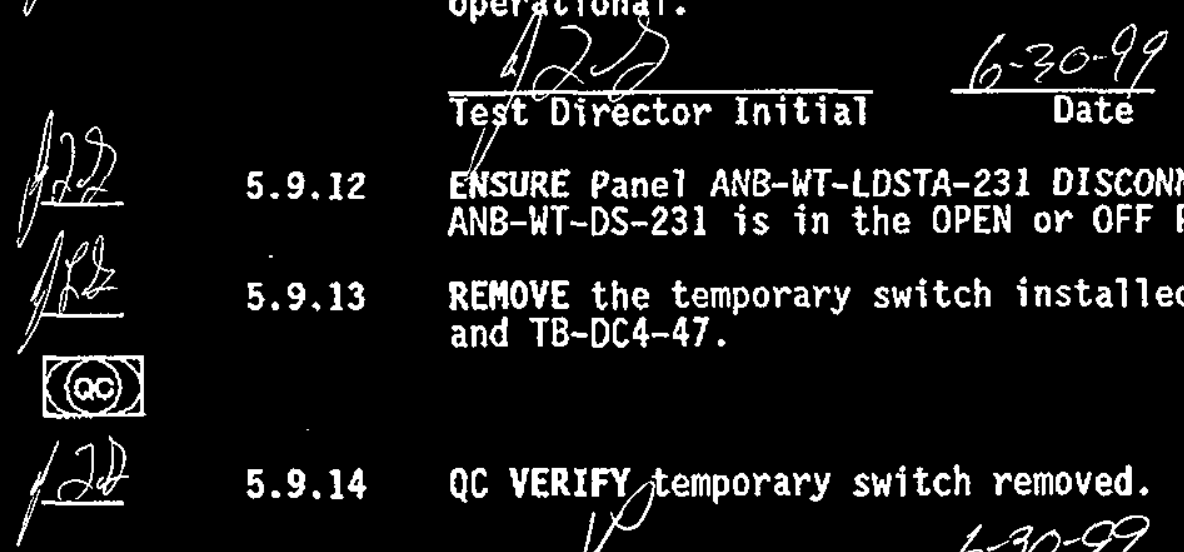

5.9.12 EISURE Panel ANB-WT-LDSTA-231 DISCONNECT SHITCH ANB-NT-DS-231 is in the OPEN or OFF POsition.

5.9.13 RENOVE the temporary switch installed BETWEEN TB-DC2-31 and TB-DC4-47.

5.9.14 QC VERIFY temporary switch removed.

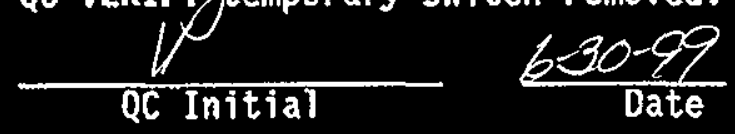

5.9.15 VERIFf that Test 5.9 is COMPLETE by SIGNING below.

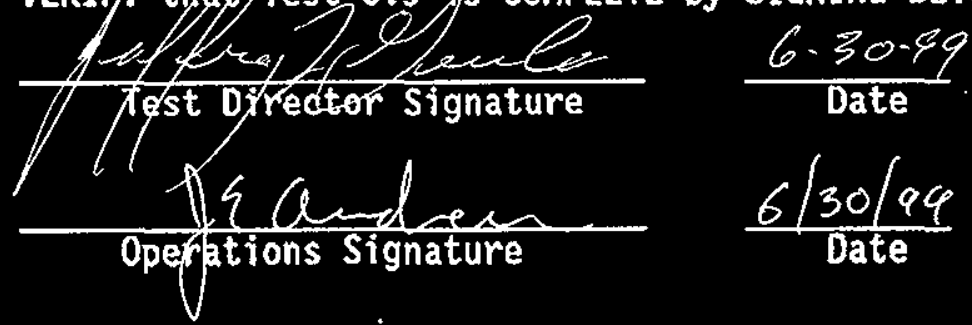

TE I RFTEST 


\subsection{BN LEAK DETECTION RELAY SWITCH TEST}

NOTE - This test verifies the functionality of the $B / M$ intrinsically safe relay. By rotating the selector switch to the "PROBE TEST" position, an internal resistor simulates a load across the probes and activates the B/H intrinsically safe leak detection relay.

ELECTRICAL TEST EQUIPMENT DATA TABLE

\begin{tabular}{|c|c|c|c|}
\hline TOOL MAME & ID. NUMBER & CAL DUE DATE & INITIAL/DATE \\
\hline FLUKF Vom & 0840 & $7.28-99$ & \% $286-30.99$ \\
\hline & & & \\
\hline & & & \\
\hline
\end{tabular}

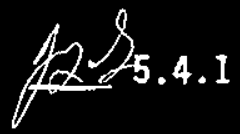

LOCATE AND ENSURE that ANB-NT-LDSTA-231 disconnect switch ANB-NT-DS-231 (Drawing No. H-14-100989) is in the CLOSED position or ON, AND the local alarm strobe 7 ight is deactivated.

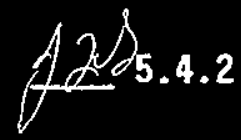

ROTATE selector switch ANB-WT-SS-231 to the "PROBE TEST" position, THEX RELEASE allowing spring return to the "Operate" position.

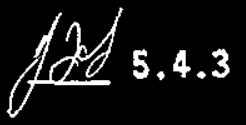

VERIFY that the local strobe light alarm ANB-NT-LDA-231A located on ANB-WT-LDSTA-231 is activated.

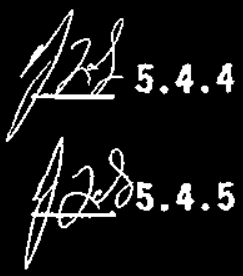

Test Director Initial

$$
\frac{6 \cdot 30-99}{\text { Date }}
$$

ROTATE AWD HOLD selector switch ANB-WT-SS-231 to the "PROBE TEST" position.

MEASURE AND RECORD the voltage BETHEEN Termina7 TB-DC2-35 and TB-DC2-34 in Field Terminal Box AN241-NT-TBX-101.

$$
\text { VOLTAGE } 0.03
$$

TE I RETEST 
5.4 BN LEAK DETECTION RELAY SWITCH TEST (Cont).

12.45 .6
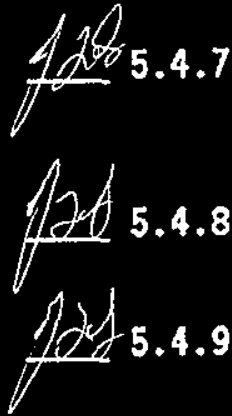

5.4 .8

5.4 .9

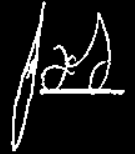

5.4 .10

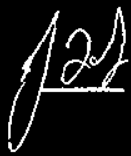

5.4 .11

5.4 .12
VERIFY the voltage recorded in Step 5.4.5 is at a nominal value of "o" volts dc.

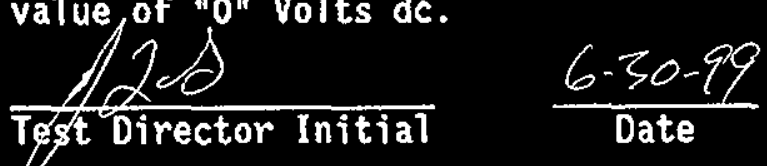

RELEASE selector switch ANB-WT-SS-331 from the "PROBE

TEST" position. (Switch should return to "OPERATE" position).

LOCATE AND ACTIVATE the "ALARM RESET" Switch ANB-WT-PB-231C.

VERIFY the local strobe light alarm in Step 5.4.3 is nOr operating.

$\frac{2 \mathrm{~A}}{\text { Test Director Initial }} \frac{6-30-99}{\text { Date }}$

MEASURE AND RECORD the voltage BETWEEN Terminal TB-DC2-35 and TB-DC2-34 in Field Terminal Box AN241-NT-TBX-101.

$$
\text { VOLTAGE } 24.0
$$

VERIFY the voltage recorded in Step 5.4.10 at a nominal value of " 24 " Voits $\mathrm{dc}$.

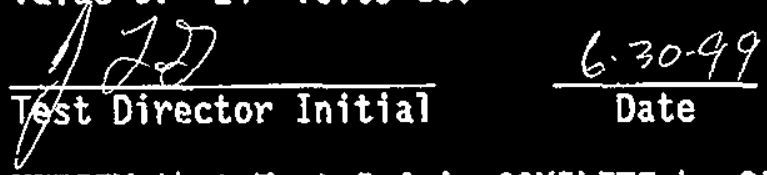

VERIFY, that Test $\mathbf{5 . 4}$ is COMPLETE by SIGNING below.

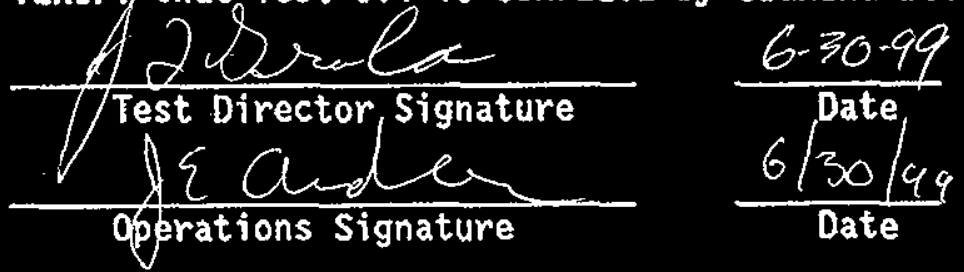

TE I RETEST 


\subsection{MTL FAIL SAFE RELAY SWITCH TEST}

NOTE - The leak detection fail safe relay switch test identifies the functionality of the fail safe testing circuit. The test relay opens a probe circuit wire and activates the MTL Trip Amplifier.

ELECTRICAL TEST EQUIPMENT DATA TABLE

\begin{tabular}{|l|l|l|l|}
\hline TOOL NAME & ID. NUMBER & CAL DUE DATE & INITIAL/DATE \\
\hline FLOKE VOM & 0840 & $7-28-99$ & $286.30-99$ \\
\hline & & & \\
\hline & & & \\
\hline
\end{tabular}

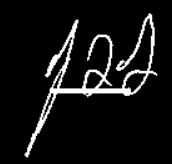

5.7 .1
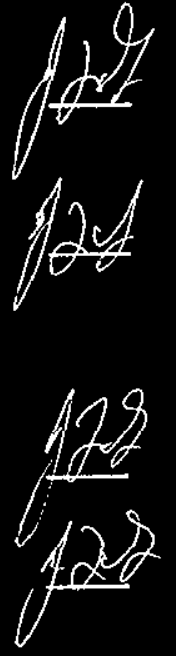

5.7 .4

5.7 .5

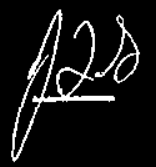

5.7 .6
ENSURE that ANB-WT-LDSTA-231 disconnect switch

ANB-NT-DS-231, reference drawing No. H-14-100989, SH. 2, is in the CLOSED position or ON, AND local strobe light alarm is DEACTIVATED.

5.7.2 ROTATE selector switch ANB-WT-SS-231 to the "FAIL RELAY TEST" position, THEN RELEASE allowing spring return to the "Operate" position.

5,7.3 VERIFY that the local strobe 1ight alarm ANB-WT-LDA-231A, reference, drawing No. H-14-100989, SH. 2, is activated.

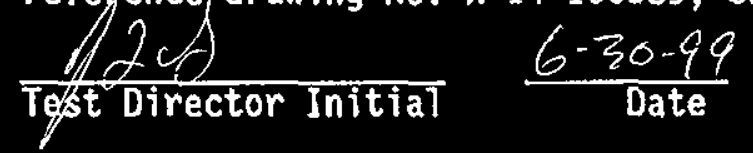

ROTATE AND HOLD selector switch ANB-WT-SS-231 to the "FAIL RELAY TEST" position.

MEASURE AND RECORD the voltage BETWEEN Terminal TB-DC2-35 and TB-BC2-36 in Field Terminal Box AN241-WT-TBX-101. VOLTAGE 0,04

VERIFY the voltage recorded in step 5.7 .5 is at a nominal value of "on Volts dc.

$\frac{228}{\text { Tegt Director Initiat }} \frac{6-3099}{\text { Date }}$

TE RETEST

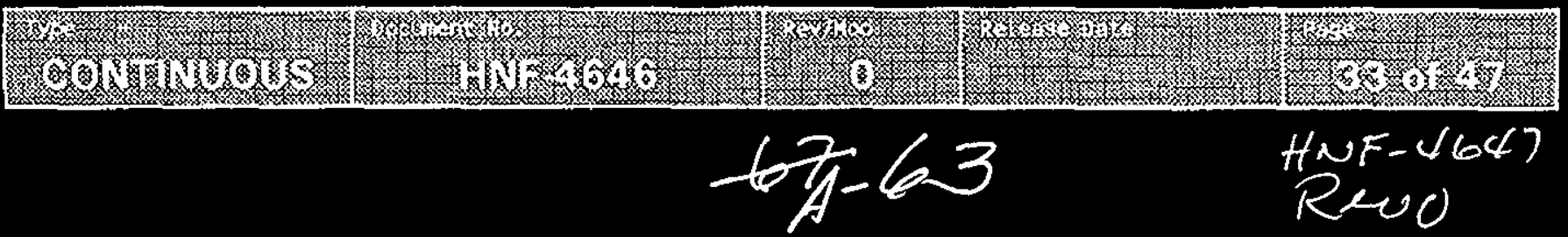




\section{5,7 MTL FAIL SAFE RELAY SWITCH TEST (Cont.)

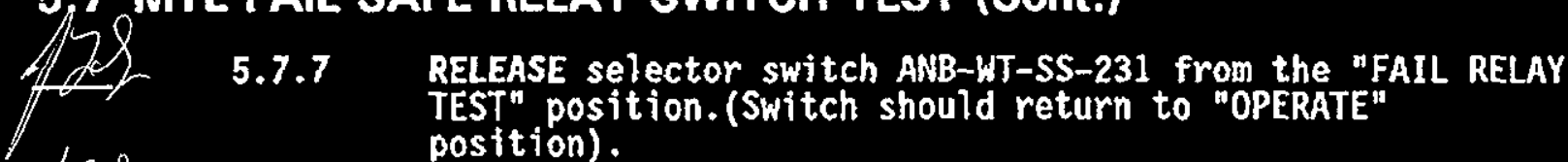

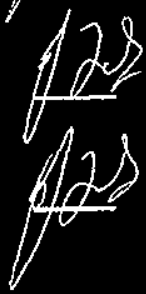

5.7.8 LOCATE AND ACTIVATE the "ALARM RESET" Switch ANB-WT-PB-231C, reference drawing $\mathrm{H}-14-100989$, SH. 2.

5.7.9 VERIFY the local strobe light alarm is NOT operating.

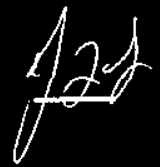

5.7 .10

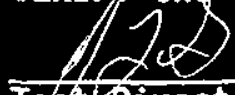

\section{Tegt birector Initial}

$\frac{6-30.99}{\text { Date }}$

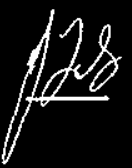

5.7 .11

UEASURE AND RECORD the vo]tage BETWEEN Terminal TB-DC2-35 and $T B-D C 2-36$ in Field Terminal Box AN241-WT-TBX-101. VOLTAGE $24.0 \%$

VERIFY the voltage recorded in Step 5.7 .10 is at a nominal value of "24" Volts dc.

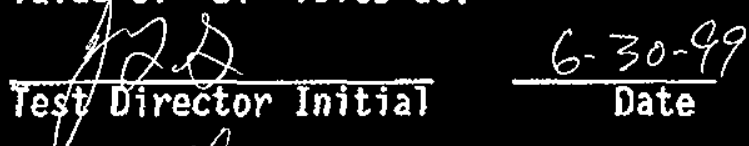

5.7.12 VERIFY that Test 5.7 is COMPLETE by SIGNING below.

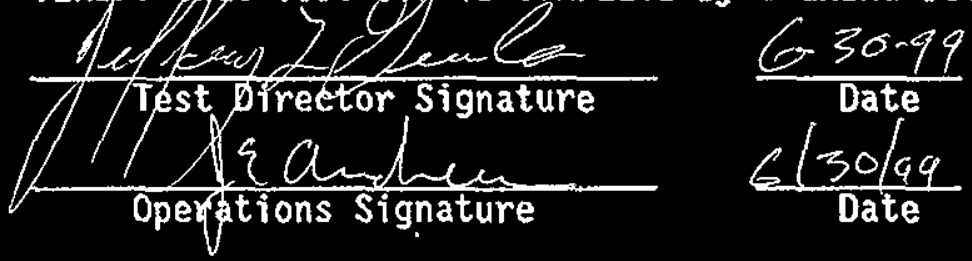

TE ${ }^{*}$ RETEST 


\section{ATP EXCEPTION RECORD}

This page may be reproduced as necessary. Page 1 of 2

\begin{tabular}{|c|c|}
\hline \multirow{2}{*}{$\begin{array}{l}\text { ATP STEP NuMBer: } \\
5.10 .7,5.10 .11 \\
\text { Description of ExEEPTiOH: VOLTHGE } 224 \text { VDC }\end{array}$} & $\begin{array}{l}\text { ATP ExcEPTIOH LOG\#: } \\
2\end{array}$ \\
\hline & \\
\hline JEFFGRUBA STARTUP & \\
\hline
\end{tabular}

REsocurion of ExcEPIION: ACLEPT RECORDED VOLTAGES AS A

NOMINAL VALUE OE 24 VOLTS

Date of Exception:

$6-30-99$

Date of Resolution:

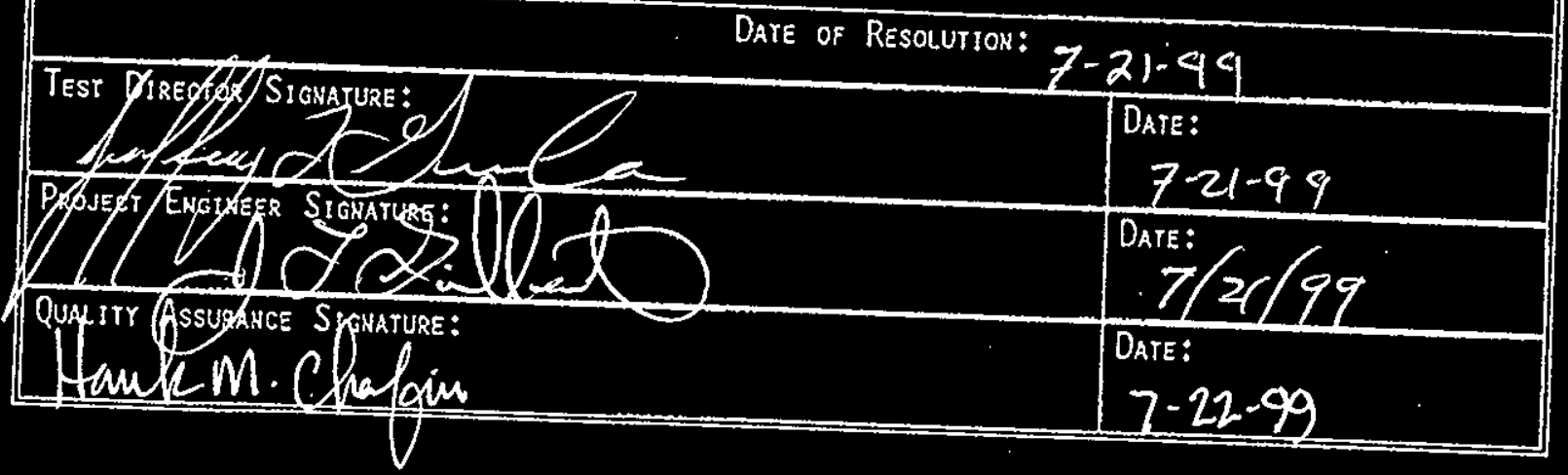


HNF-4646

Test Exception 2

Page 2 of $\underline{\underline{Z}}$

Planned Resolution

Read S-1 switch to earth to verify no path to earth. Read across switch contacts to verify switch is open.

If no path to earth or short across switch is present continue with test.

Justification

The intent of the voltage verification is to verify that the switch is OPEN. A small voltage drop across the switch is not detrimental to the test. A review of the drawing H-14-100989 Rev. 2, Sht. 2, does not show an alternate path for voltage drop.

Conclusion

The test switch will perform its intended function of simulating the HMI RESET and TESTFLR handswitches.

Resolution of Exception.

Readings across the S-1 switch with the test FLUKE VOM indicate the switch is OPEN.

Reading from the S-1 switch case to earth, indicates no short to earth is present.

Accept reading of $22.19 \mathrm{Vdc}$ and $22.17 \mathrm{Vdc}$ as in the "nominal range of 24 Volts dc."

The voltage drop across the S-1 test switch occurred at the following test steps.

\begin{tabular}{|l|l|l|}
\hline TEST STEP & RELAY & INSPECTED FOR SHORT CIRCUITS \\
\hline 5.10 .7 & K-331B & Switch inspected no faults found \\
\hline 5.11 .7 & K-331A & Switch inspected no faults found \\
\hline
\end{tabular}




\section{ATP EXCEPTION RECORD}

This page may be reproduced as necessary.

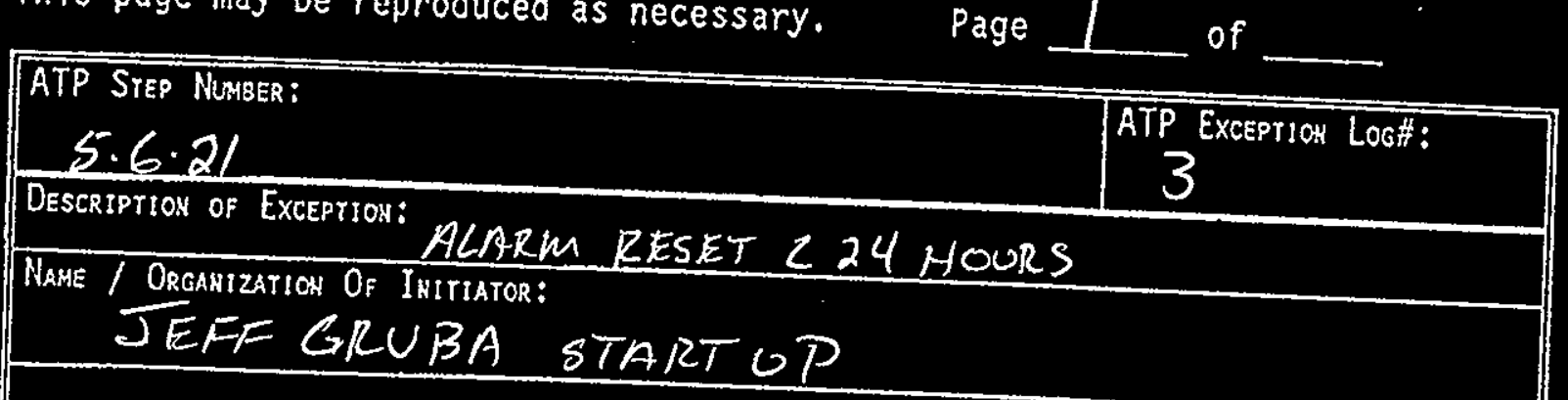

Resolution OF EXCEPTION: REMOVED PLUG REPLACED RUBBER GASKET

RESET PROBE. SECTIONS 5.3

DATE of Exceprion:

RETEST GEAR DETECTOR SECTION 5.6

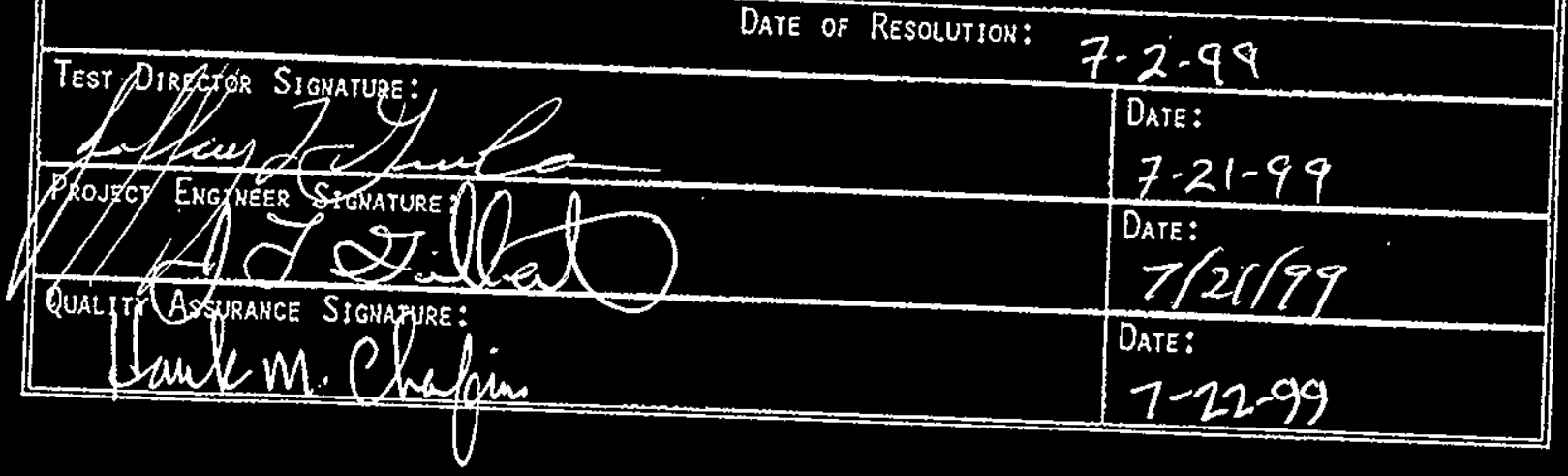


HNF-4646

Test Exception 3

Page 2 of

Planned Resolution

Return to construction for investigation and rework as required in accordance with their program.

Justification

The sealing gasket is still in final resolution with engineering and construction.

The type of gasket material and characteristics may require several in-situ tests in order to obtain a leak tight fit.

\section{Conclusion}

Retest as required to verify leak tight condition.

Resolution of Exception.

The drain plug valve was removed, reworked, and reinstalled. In addition the leak detection probes were reset to a lower elevation in accordance with clarified interpretation of the probe configuration. The probe is actually mounted $3 / 16$ of an inch above the bottom of the probe case. This was not compensated for when the probe was originally set in step 5.3. The original setting of $3 / 8$ inch from the valve pit floor as determined by the detector case. Despite the higher elevation the probes still detected the leak. However this was not the case with the ANA Valve pit Leak Detector Probe. This resulted in ECN 654959 that provided clarification. The ANB Valve Pit Leak Detector Probe was reset to maintain a consistent configuration with the probe elevations.

The results of the sealing gasket rework and the lowering of the leak detection probe has resulted in a satisfactory test. 


\section{ENGINEERING CHANGE NOTICE}

\begin{tabular}{|c|c|c|c|c|c|}
\hline 2. ECN Category (mark one) & $\begin{array}{l}\text { 3. Originator's Name, Ors } \\
\text { Carol cloud, TWE }\end{array}$ & $\begin{array}{l}\text { ization, MSIN, and Telepho } \\
\text { G3-12, } 376-736\end{array}$ & vo. & $\begin{array}{l}\text { SQ Required? } \\
\text { les ONo } \\
-99-8525\end{array}$ & $\begin{array}{l}\text { 5. Date } \\
7-1-99\end{array}$ \\
\hline $\begin{array}{l}\text { Change ECN } \\
\text { Temporary }\end{array}$ & $\begin{array}{l}\text { 6. Project Tite/No.Mork } \\
\text { W-314, Tank Farr } \\
\text { Safe Operations }\end{array}$ & $\begin{array}{l}\text { derNo. } \\
\text { Restoration and }\end{array}$ & $\begin{array}{l}\text { 7. Bidg./Sys. } / \mathrm{F} \\
241-\mathrm{AN} \\
\end{array}$ & No. & $\begin{array}{l}\text { 8. Approval Designator } \\
\mathrm{SC} / \mathrm{SQ}=\end{array}$ \\
\hline $\begin{array}{l}\text { Standby } \\
\text { Supersedure } \\
\text { Cancel/Noid }\end{array}$ & $\begin{array}{l}\text { 9. Document Numbers C } \\
\text { sheet no. and rev.) } \\
\text { See block } 13 a\end{array}$ & nged by this ECN (includes & $\begin{array}{l}\text { 10. Related EC } \\
\text { NONE }\end{array}$ & No(s). & $\begin{array}{l}\text { 11. Related PO No. } \\
\text { N/A }\end{array}$ \\
\hline $\begin{array}{l}\text { 12a. Modification Work } \\
\text { Yes (fill out Blk. 12b) } \\
\text { No }\left(N_{2 \mathrm{C}} \text { Blks. } 12 \mathrm{~d} \text { ) }\right.\end{array}$ & $\begin{array}{l}\text { 12b. Work Package No. } \\
\text { N/A }\end{array}$ & $\begin{array}{l}\text { 12c. Modification Work Co } \\
\frac{N / A}{\text { Design Authority/Cog. Er }}\end{array}$ & eer Signature \& & $\begin{array}{l}\text { 12d. Restored } \\
\text { or Stand } \\
\mathrm{N} / \mathrm{A} \\
\text { Design Auth }\end{array}$ & $\begin{array}{l}\text { to Original Condition (Temp. } \\
\text { y ECNs only) } \\
\text { ity/Cog. Engineer Signature \& } \\
\text { Date }\end{array}$ \\
\hline
\end{tabular}

Affected documents:

H-14-100985，SH. I, REV. 1

H-14-100986, SH. I, REV. I

Description of change:

H-14-100985, SH. 1, REV. 1

Revise per what is shown in clouded area on page 4 .

H-14-100986, SH. 1, REV. 1

Revise per what is shown in clouded area on page 5 .

Background changes for this drawing, not identified by a revision bubble, are reflected in related $\mathrm{ECN}^{\prime} \mathbf{s}$.

\section{4a. Justification (mark one) \\ Criteria Change \\ Design Improvement \\ Environmental \\ Facility Deactivation \\ As-Found \\ Facilitate Const. \\ Const. Error/Omission \\ Design Error/Omission \\ 0}

14b. Justification Details

0

0

0

O) This modification will not change collective

O

0 original nominal pit construction tolerances. sources, contamination control, or shielding. review. This ECN lowers the probe height on the Pit Leak Detectors for Valve-Pits 241-AN-A and 241-AN-B. This was necessary to aid the field during Construction Testing. The lower probe height meets al1 requirements in the PDS, HNF-SD-W314-003 and takes into account the

This ECN does not affect AN RVR or STEPS for AN-A or AN-B. The design verification method for SC components is by independent review as documented on the attached record of the

15. Distribution (include name, MSIN, and no. of copies)

See attached Distribution sheet 3

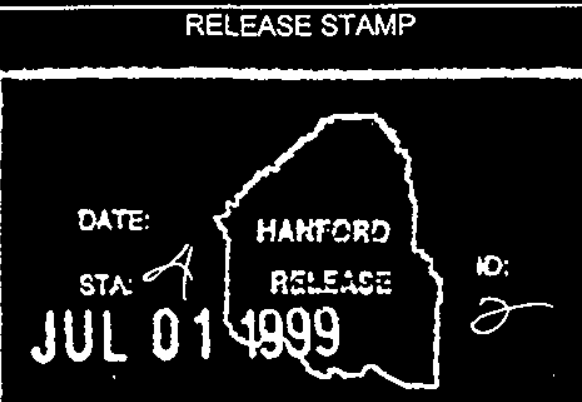




\section{DISTRIBUTION SHEET}

\begin{tabular}{|l|l}
\hline To & From \\
Distribution &
\end{tabular}

Project Title/Work Order

W-314 Tank Waste and Restoration

NAME

J. P. Bedell

T. W. Bohan

D. E. Bowers

W. E. Bryan

R. F. Carlstrom

H. M. Chafin

G. S. Chinery

M. S. Collins

T. A. Dillhoff

R. A. Dodd

R. E. Elder

R. E. Eish

J. D. Galbraith

M. S. Garrett

J. L. Gilbert

J. S. Hammers

B. H. Hays

J. W, Hobbs

O. M. Jaka

E. M. Koellermeirer

M. A. Lane

J. R. Lapointe

K. W. Leliefeld

J. W. Lentsch

D. L. McGrew

J. W. Middleton

C. H. Mulkey

J. E. Navarro

D. W. Reberger

P. D. Rhodes

C. A. Rieck

W. R. Swift

B. I. Syverson

D. W. VanDyke

J. A. Wright

T. I. Warnick

M. W. Wheat

Construction Document Control
MSIN

G3-12

R3-47

S $5-13$

S5- 05

$\mathrm{R} 1-4 \dot{3}$

$\mathrm{R} 3-25$.

N1 -29

A $5-18$

S5-0.3

$\mathrm{R} 3-72$

S6-14

$\$ 5-50$

R3-73

SO-09

R3-25

R3-25

B2-69

S6-14

S5-12

A3-04

G3-12

R2-88

SO-09

R3-25

R3-25

B4-68

R1-51

A2-22

S5-13

SO-09

S2-48

S5-50

G3-12

(IPE 23)

R2-82

S5-50

G3-12

SO-09

S5-50
DRAWINGS SPECS

ECN

5 HS

1 HS

1 HS

$1 \mathrm{HS}$

$1 \mathrm{HS}$

1 HS

$1 \mathrm{HS}$

1 HS

$1 \mathrm{HS}$

1 HS

1 HS

$1 \mathrm{HS}$

$1 \mathrm{HS}$

$1 \mathrm{HS}$

1 HS

2 HS

1 HS

1 HS

1 HS

$1 \mathrm{HS}$

$1 \mathrm{HS}$

$1 \mathrm{HS}$

1 HS

5

1

1

1

1

1

1

1
1

1

1

1

1

1

1

1

1

2

1

1

1

1

1

1

$1 \mathrm{HS}$

3

1 HS

1 HS

1

4 HS/1OFS 6

For changes in Distribution, please contact Tammy Rettkowski at 372-2559 or Iinda syverson on 376-0486.

$$
\begin{array}{cc}
A-70 & H N F-4647 \\
\text { ReNO }
\end{array}
$$




\begin{tabular}{|c|c|c|c|c|c|c|}
\hline$H-14-100985$ & 1 & 1 & CL CLOUD & $\beta X C a m s t$ & $\begin{array}{l}\text { Den no } \\
-W 314-4 C-124\end{array}$ & $4 / 6$ \\
\hline
\end{tabular}

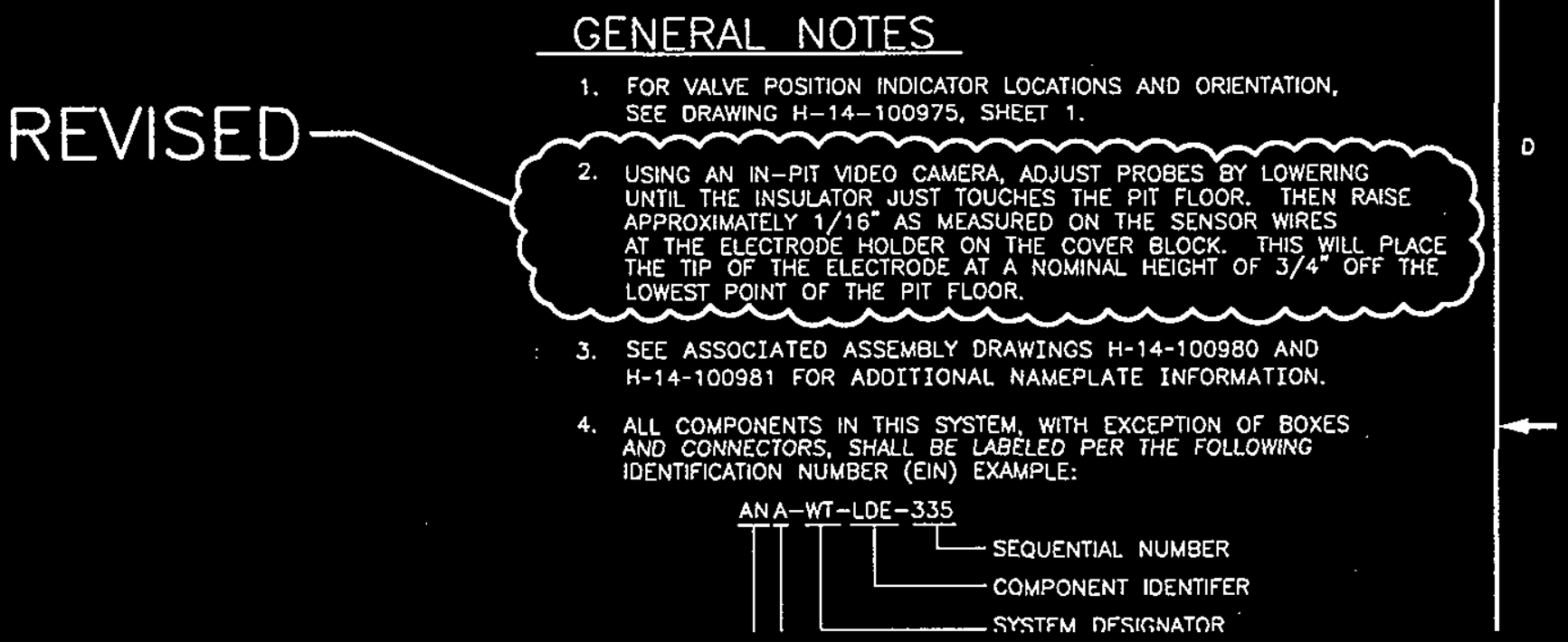




\begin{tabular}{|c|c|c|c|c|c|c|}
\hline $\mathrm{H}-14-100986$ & t & 1 & $\begin{array}{l}\text { Flenend } \mathrm{CLO} \\
\mathrm{CL}\end{array}$ & Chankiod CY & $W 314-4 C-124$ & $5 / 6$ \\
\hline
\end{tabular}

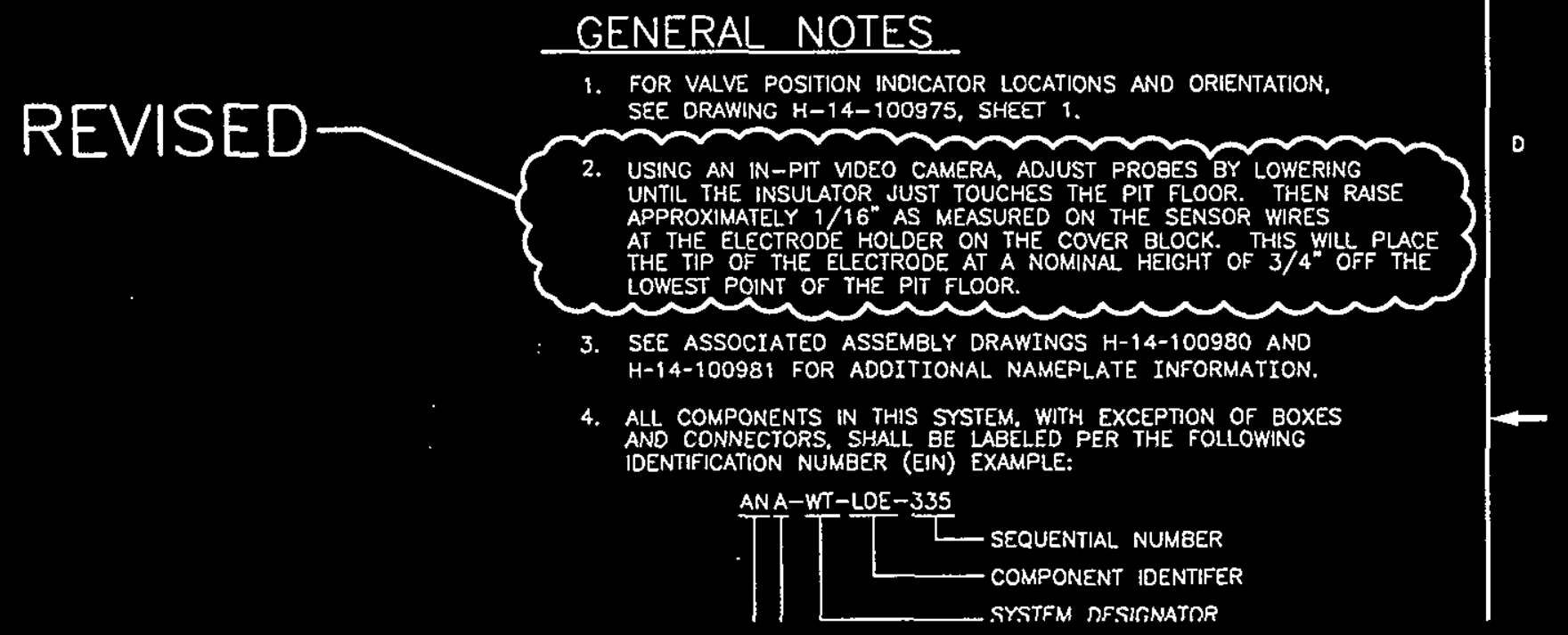


PROJECT W-314, TANK FARM RESTORATION AND SAFE OPERATIONS DOCUMENTATION OF INDEPENDENT REVIEW

EON NUMBER W3/4 - $4 \mathrm{C}-124$

Guidelines for review:

- Meets functional requirements

- $\quad$ Proper design inputs used

- Reasonable assumptions made

- Methods of calculation correct

- Structural integrity adequate

- Interfaces correct

- Tolerances reasonable

- Materials and sizes standard (readily available

Independent reviewer's name

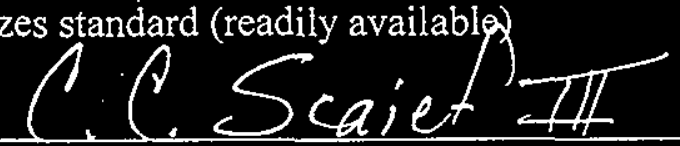

Design verification method used

Design inputs

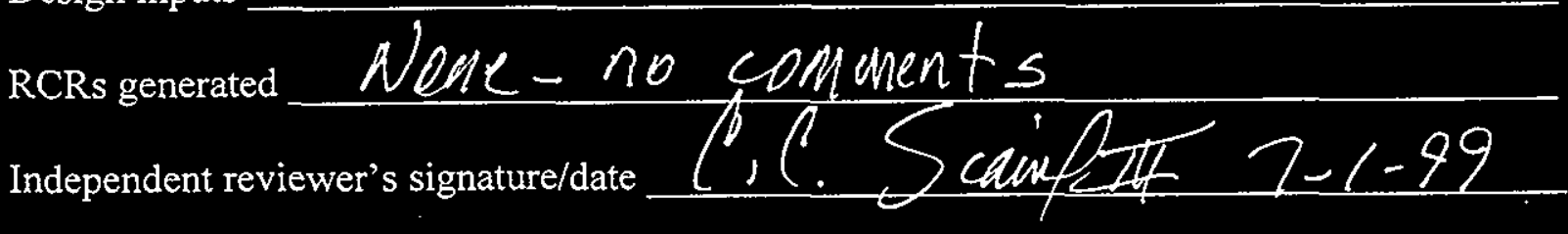

Cognizant manager's signature/date

Attach this form to the applicable ECN after completion of review.

HNF-4647

$A \cdot 73$

ReNd 


\subsection{BN LEAK DETECTION RELAY LEAK SIMULATION TEST}

NOTE - The B/W leak detection relay leak simulation tests the probe circuit by adding liquid to the $241-A N-B$ valve pit. Adding Salt Water to the $241-A N-B$ valve pit will be detected by the probe circuit and local alarms and remote signals will be generated.

ELECTRICAL TEST EQUIPMENT DATA TABLE

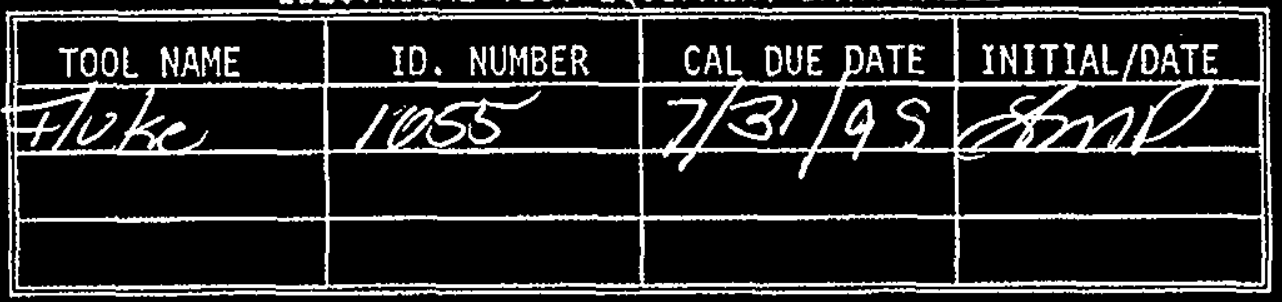
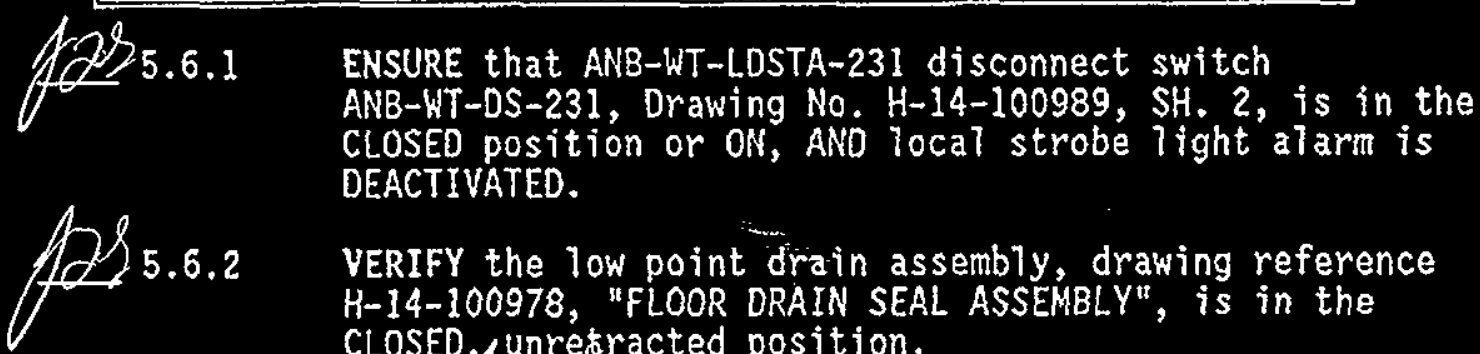

VERIFY the low point drain assembly, drawing reference H-14-100978, "FLOOR DRAIN SEAL ASSEMBLY", is in the CLOSEO, unresracted position.
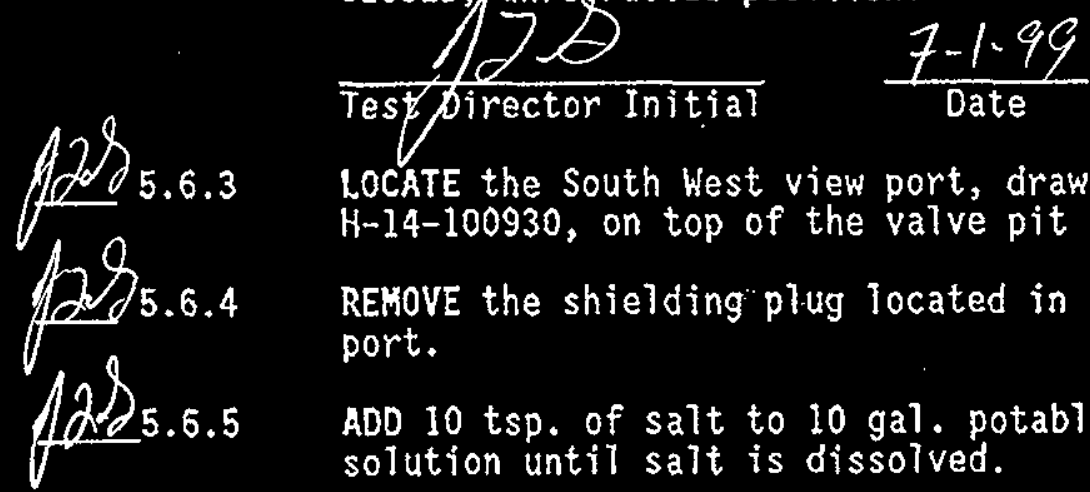

LOCATE the South West view port, drawing reference H-14-100930, on top of the valve pit cover block.

REHOVE the shielding plug located in the cover block view port.

ADD $10 \mathrm{tsp}$. of salt to $10 \mathrm{gal}$. potable water and stir solution until salt is dissolved.

NOTE - Use care to avoid splashing salt solution on jumpers in pit during water addition.

NOTE - In the following step 1 iquid will be introduced to the pit. At a rate not to exceed $16 \mathrm{oz} . / \mathrm{min}$. (Maximum of 10 gal. total).

NOTE - Stop adding liquid to pit when leak detection alarm actuates.

fol 5.6.6 POUR Salt water solution into the view port.

\section{TEST EXCEPTION 3 RETEST}


5.6 BN LEAK DETECTION RELAY LEAK SIMULATION TEST (Cont.)

129.6

RECORD, On TABLE 2 the start time for the liquid being poured into the valve pit.

TABLE 2

\begin{tabular}{|c|c|c|}
\hline 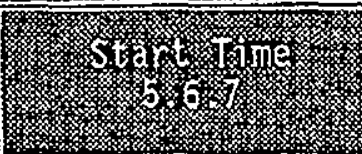 & 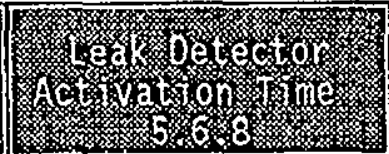 & Amour \\
\hline 1453 & $15 / 2$ & 25 \\
\hline
\end{tabular}

C.sint 5.6 .8

comp.6.9

etone 5.6.10

RECORD, On TABLE 2 the time the leak detector activates.

RECORD, On TABLE 2 the amount of salt water solution required to activate the leak detector.

VERIFY the amount of salt water solution required to activate the leak detector is less than or equal to 10 gallons.
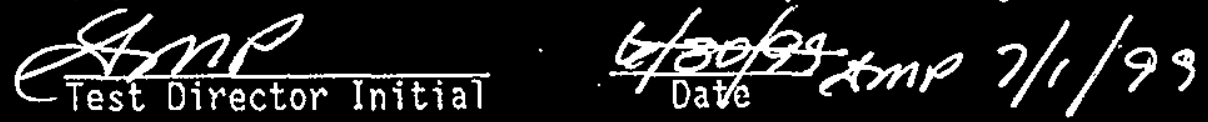

$\operatorname{cen} 5.6 .11$

VERIFY that the local strobe Tight alarm ANB-WT-LOA-231A located on ANB-WT-LDSTA-231 is activated.

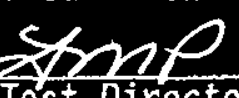

Test Director Initial

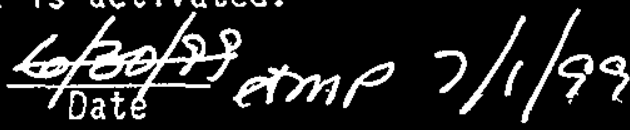

NOTE - The MPS is jumpered out and MPS system should NOT receive a shutdown signal.

AmP 5.6.12. ADD remaining 1 iquid using caution not splash solution on jumpers and devices in pit.

xtrot 5.6 .13

$\sin \rho_{5.6 .14}$

(s)

$\tan 5.6 .16$

$e^{x-1}$
RECORD on ALARM RESET DATA TABLE, the time liquid addition is complete.

INSTALL shield plug removed in step 5.6.4.

LOCATE AND ACTIVATE the "ALARM RESET" Switch ANB-WT-PB-231C

located on ANB-WT-LOSTA-231.

VERIFY the jocal strobe Jight al arm remains operational.

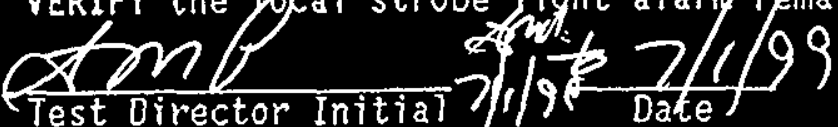

MEASURE AND RECORD the voltage BETHEEN Terminat TB-DC2-35 and TB-DC2-34 in Field Terminat BOX AN241-WT-TBX-101.

VOLTAGE

TF" R RETEST 


\subsection{BN LEAK DETECTION RELAY LEAK SIMULATION TEST (COnt.)}<smiles>[AsH3][As]1C=C[C@H]2CC[C@H]1C2</smiles>

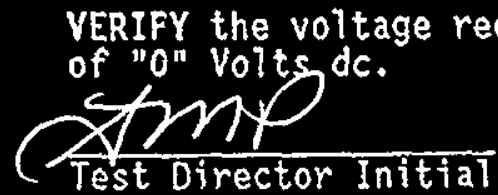

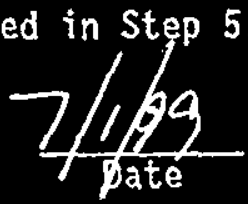

NOTE - During the next 24 hour perjod the ALARM reset switch ANBWT PB-231C located on ANB-WT-LDSTA-231 will be actuated at least once every 60 minutes until alarm condition clears, or the 24 hour period is exceeded. It is recommended to attempt reset of alarm every 30 mins. (The intent of this is to fulfill the $24 \mathrm{hr}$. requirement for drain seal).

Q.2018.6.19

LOCATE AND ACTIVATE the "ALARM RESET" Switch ANB-NT-PB-23IC At jeast once every 60 min until alarm clears or 24 period is exceeded.

RECORD each RESET attempt on ALARM RESET DATA TABLE.

TE 3 RETEST 
5.6 BM LEAK DETECTION RELAY LEAK SIMULATION TEST (Cont.)

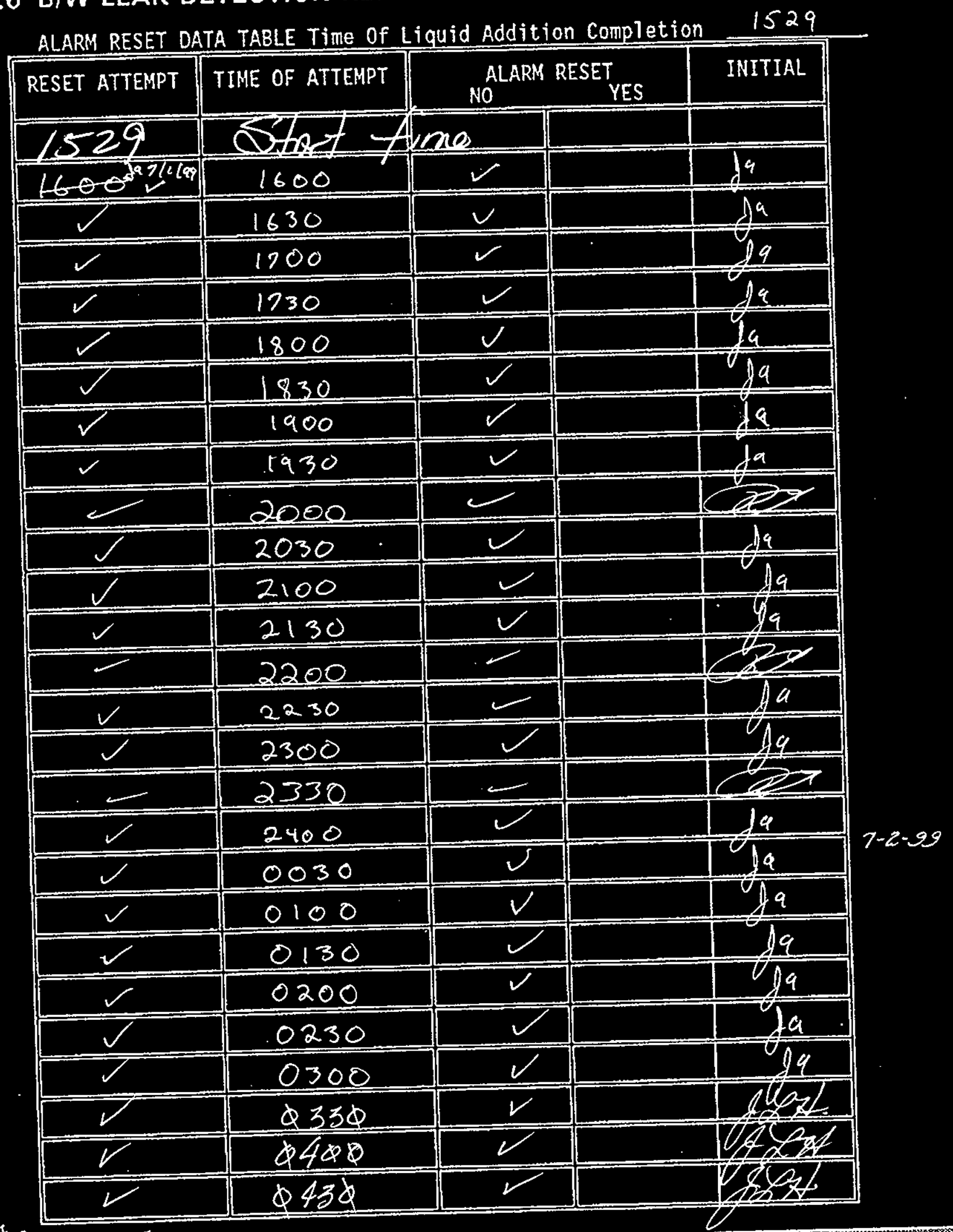

TE 3 RETEST

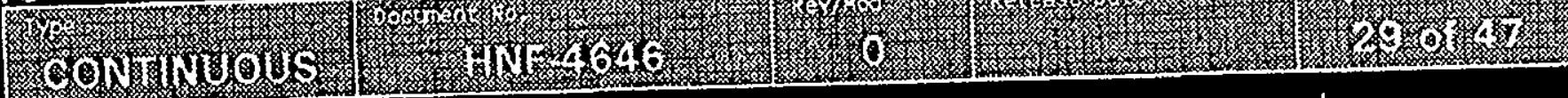

$$
\begin{gathered}
\text { SE A-77 } \\
\text { RwO }
\end{gathered}
$$




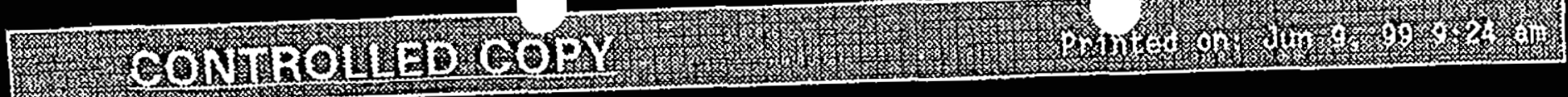
地.
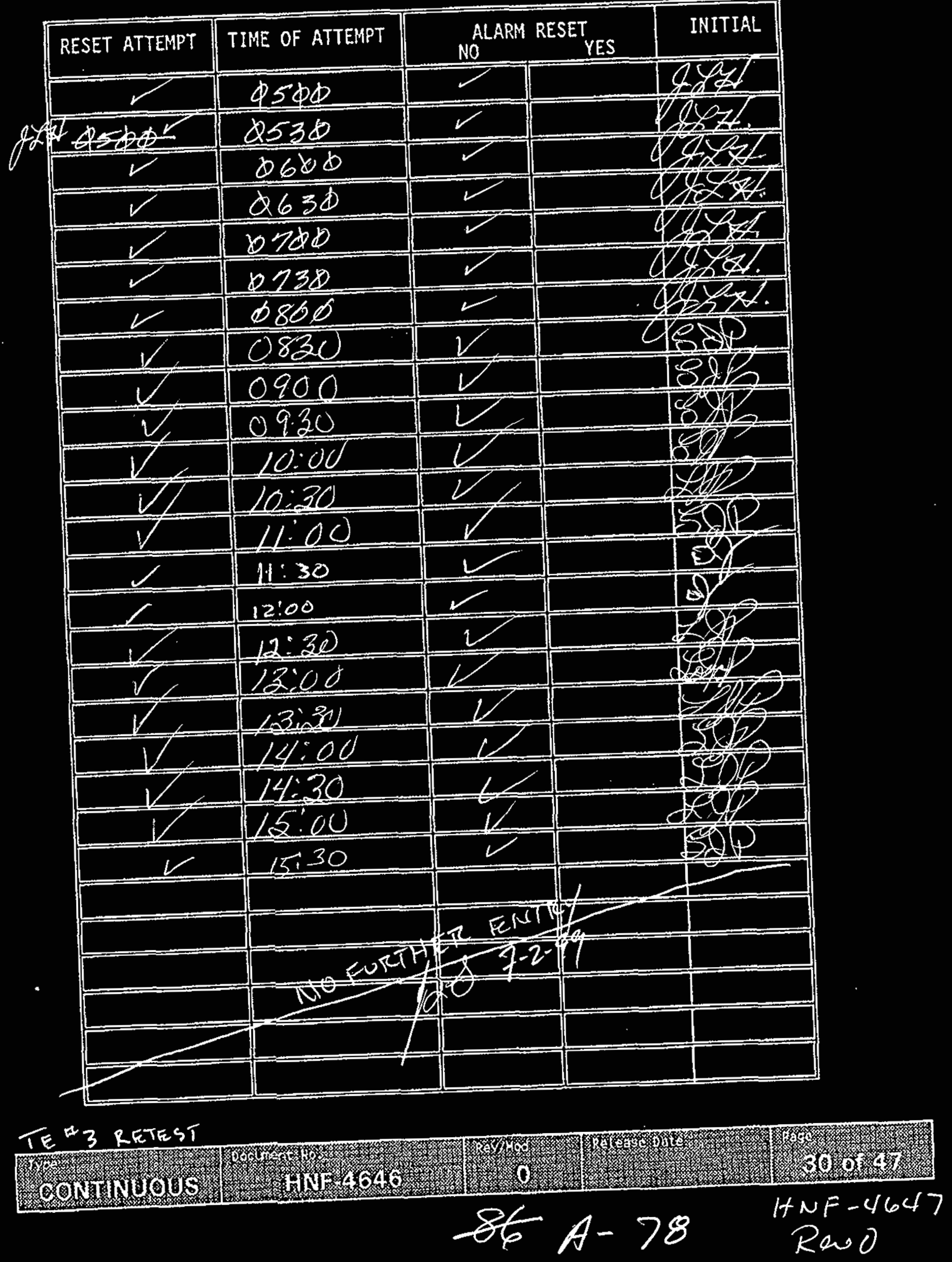


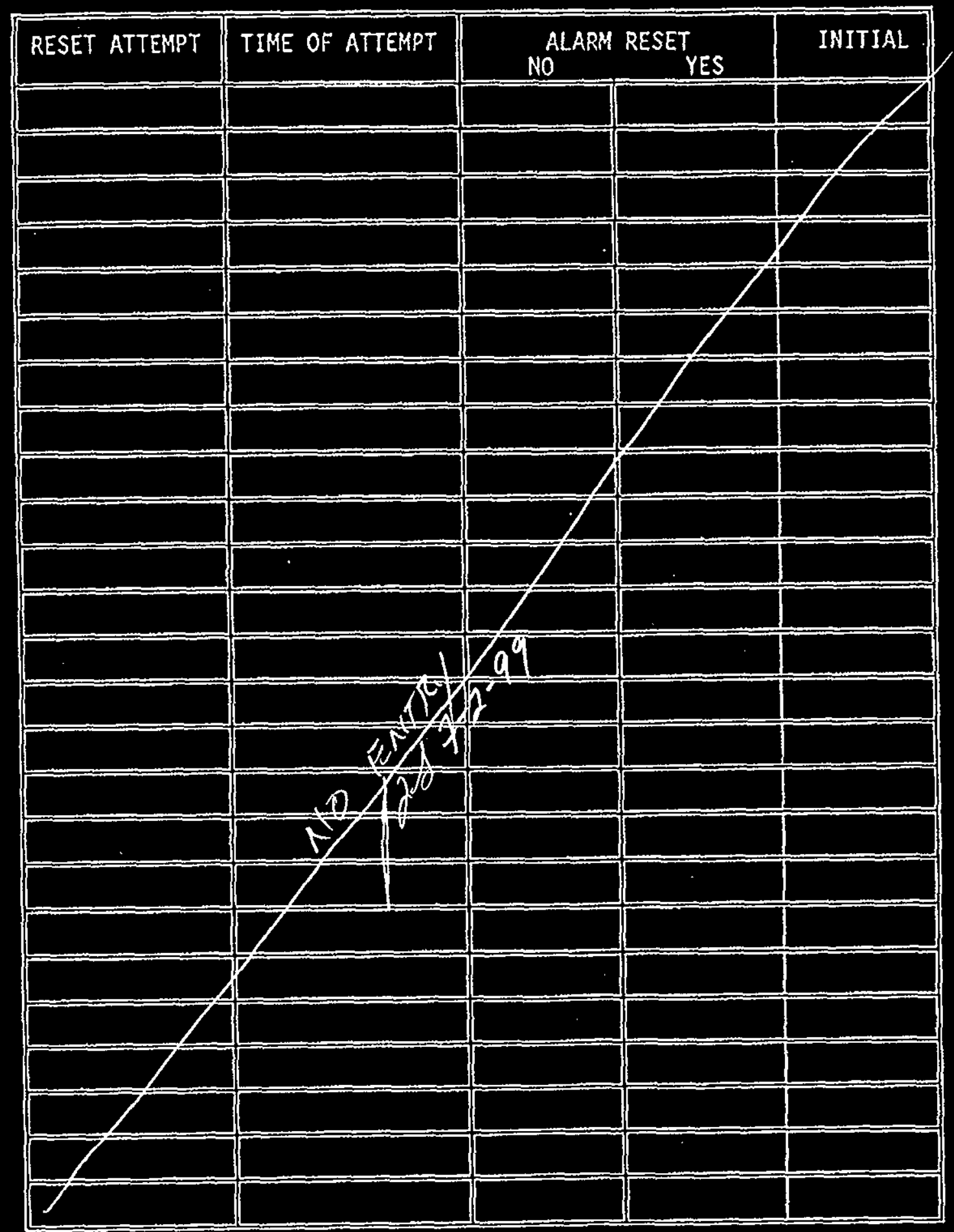

TE 3 RETEST

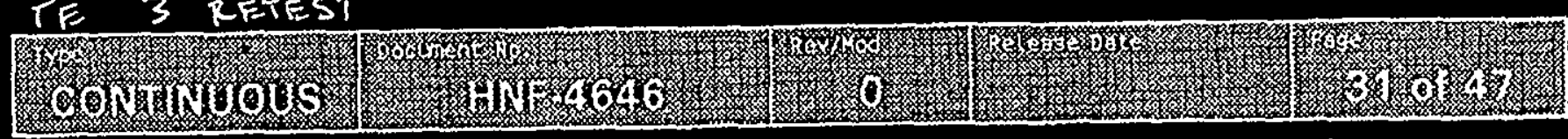

$$
\text { 87-A-79 } \begin{aligned}
& \text { HuF-4647 } \\
& \text { Ruo }
\end{aligned}
$$




\subsection{BN LEAK DETECTION RELAY LEAK SIMULATION TEST (Cont.)} LA 5.6.21 IF ALARM RESETS prior to the 24 hour 1 imit THEN document on
TEST EXCEPTION LOG AND GO TO step 5.6.24.

DV 5.6.22 PLACE the low point drain assembly in the OPEN or RETRACTED position.

DV 5.6.23 LOCATE AND ACTIVATE the "ALARM RESET" Switch ANB-HT-PB-23IC.

D 5.6.24 VERIEX the local strobe light alarm is NOT operating.
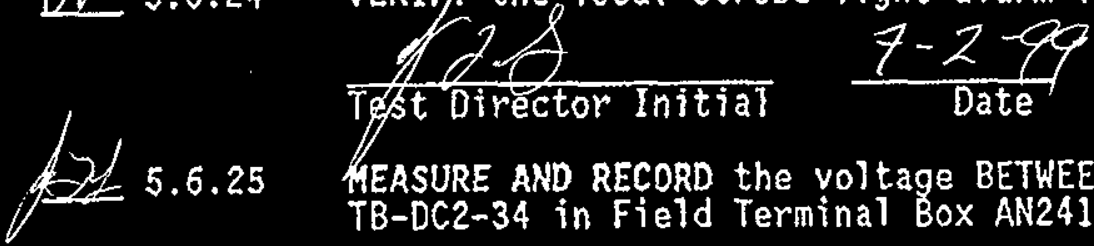
Tgtost
MEASURE AND RECORD the
TB-DC2-34 in Field Terminal Box AN241-WT-TBX-101.

vate

VOLTAGE $2 \% .0 \%$

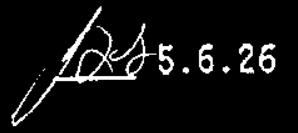

VERIFY the voltage recorded in Step of "g" Volts dc.

$\frac{24 / 28}{\text { Test pjrector Initial }} \frac{7.2 .99}{\text { Date }}$

DV 5.6.27 ENSUkE low point drain assembly is in OPEN or RETRACTED position, AND FLUSH with 10 gal. RAW WATER.

DV 5.6.28 REPEAT FLUSH with 11 gal. RAW WATER.

$D^{\prime}$ 5.6.29 REPEAT FLUSH with $12 \mathrm{gal}$. RAW WATER.

DV 5.6.30 RESTORE the low point drain as sembly to the CLOSED or UNRETRACTED position AFTER draining is complete.

5.6.31 VERIFY that Test 5.6 is COMPLETE by SIGNING below.
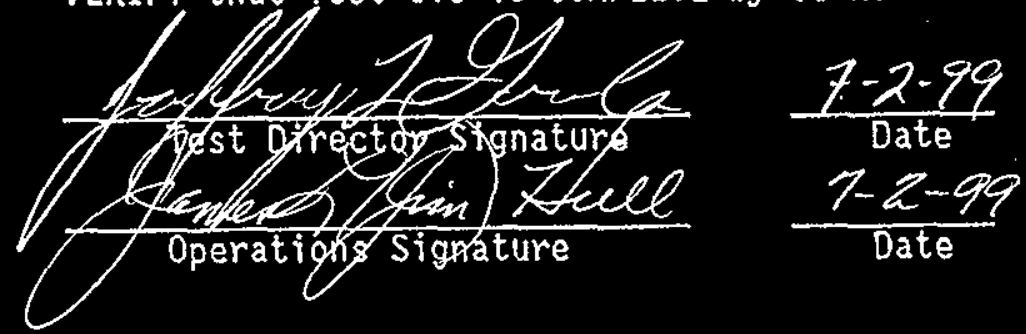

TE 3 RETEST 


\subsection{SETTING THE PROBE ELEVATIONS}

5.3.1 VERIFY IH\&S Tech, has monitored pit prior to performing this section.

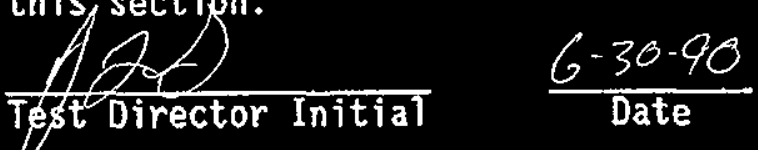

5.3.2 IMSTALL camera system for visually monitoring probe and cabies to probes per To-020-005.

ELECTRICAL TEST EQUIPHENT DATA TABLE

\begin{tabular}{|c|c|c|c|}
\hline TOOL NAME & ID. NUMBER & CAL DUE DATE & INITIAL/DATE \\
\hline A $/$ & & & \\
\hline ND & & & \\
\hline & & & \\
\hline
\end{tabular}

5.3 .3

VERIFY the probes are installed correctly. Refer to drawing H-14-100981, sht 1 \& 2, "INSTM PIT LEAK DETECTOR ASSYY.
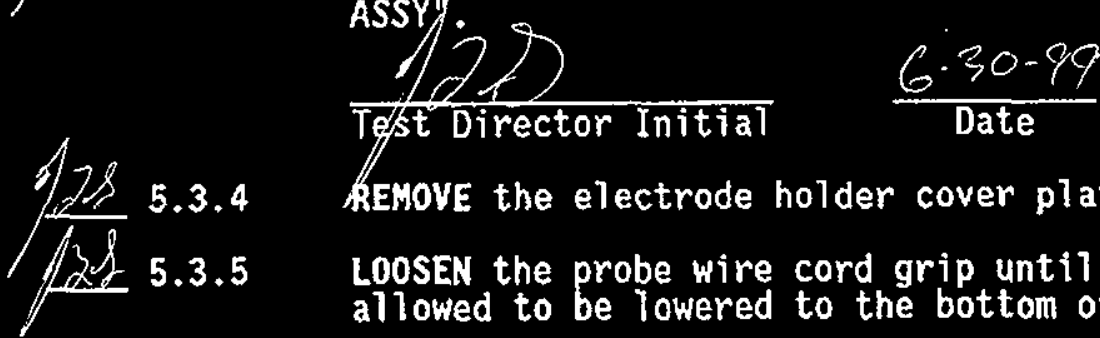

5.3.4 REMOVE the electrode holder cover plate.

5.3.5 LOOSEN the probe wire cord grip until the probe wires are allowed to be lowered to the botton of the pit floor.

NOTE - DO NOT allow slack to accumulate in the probe wires once the probes have touched the bottom of the pit floor. observe with camera system.

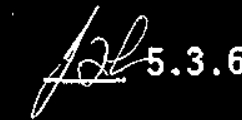

LOWER the probe wires toward the valve pit floor until the probes are just touching the pit floor.

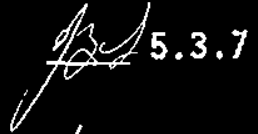

WARK the probe wires at the top of the probe wire cord grips with the use of a permanent marker or other marking device.

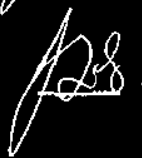

5.3 .8

RAISE the probe wires AND MEASURE a distance, down toward the electrodes, of $3 / 8(0.25$ to 0.5$)$ inches.

\section{TE 3 RETEST}

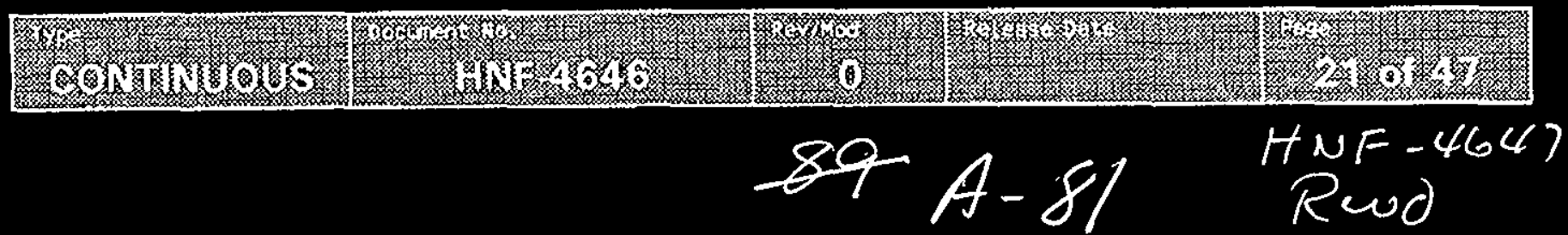




\subsection{SETTING THE PROBE ELEVATIONS (Cont).}

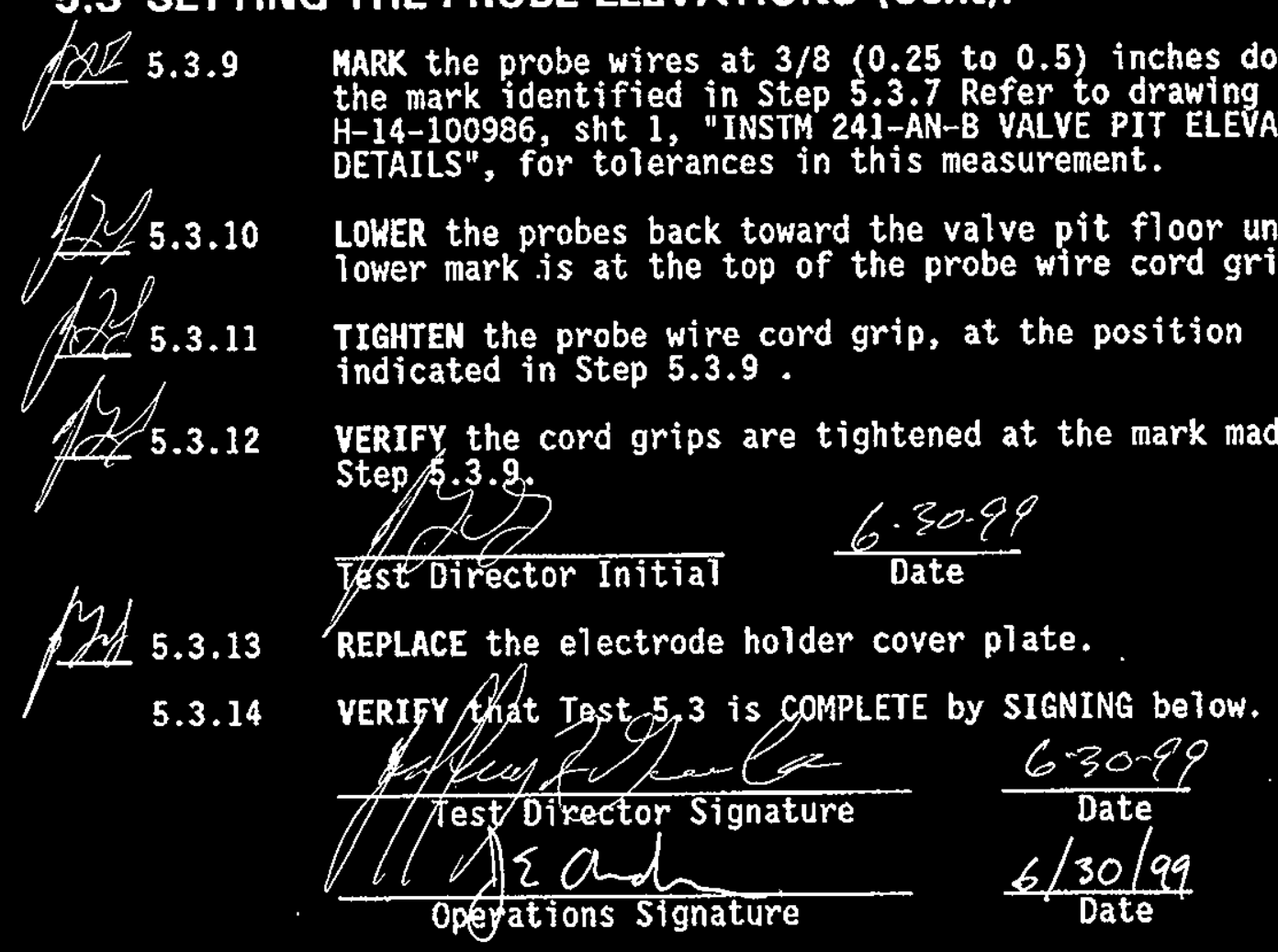

TE ${ }^{*} 3$ RETEST 


\section{ATP EXCEPTION RECORD}

This page may be reproduced as necessary. Page 1 of 3

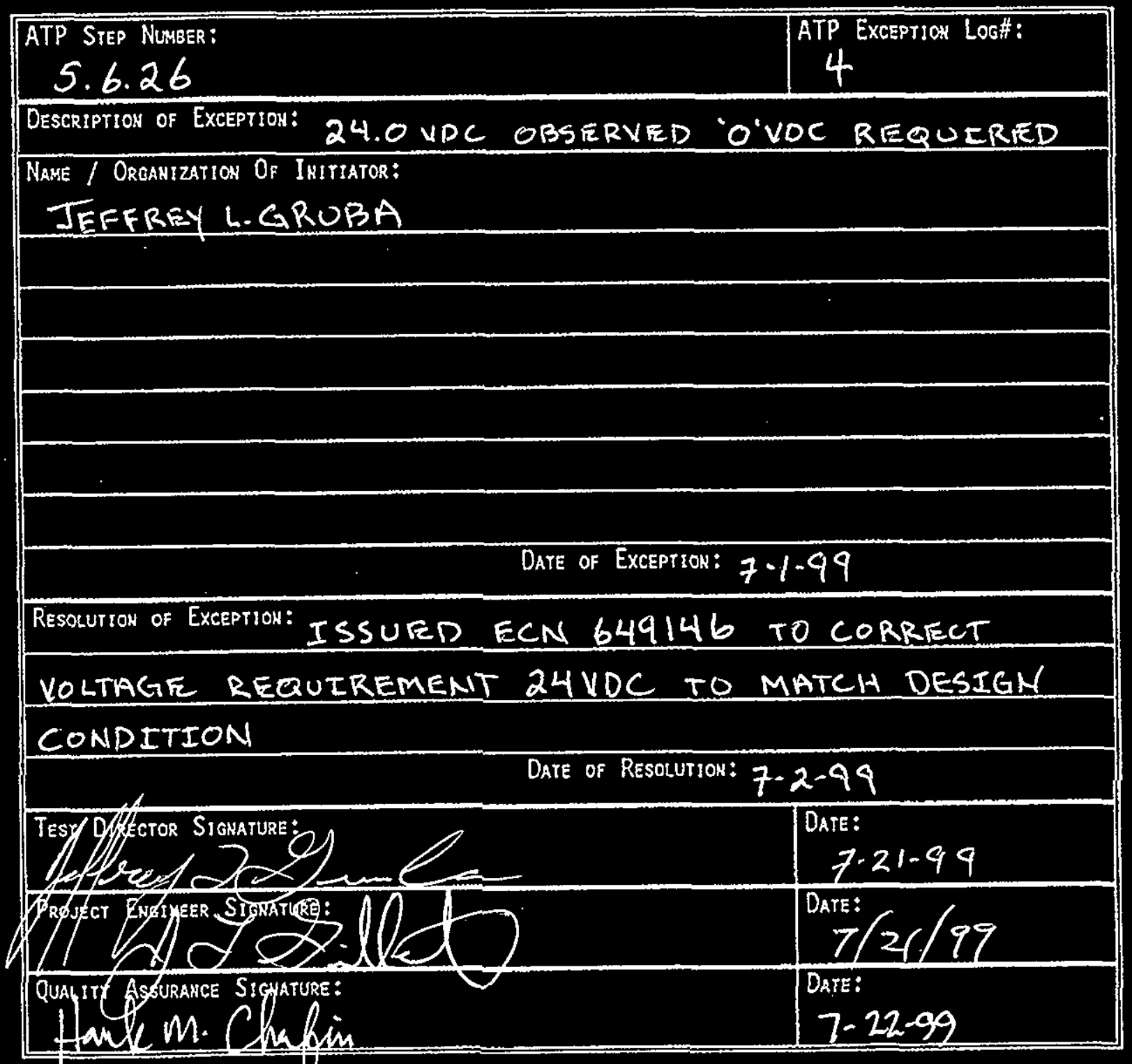




\section{ENGINEERING CHANGE NOTICE}

6. Design Verification Required

Yes the ONo $7-2.99$

17. Cost Impact ENGINEERING

Additional $O \& \ldots$ N/A Savings $O$ s

\section{CONSTRUCTION}

Additional $O \leqslant \ldots N / A$ Savings $O s$
18. Schedule Impact (days)

Improvement

O N/A

Delay

19. Change Impact Review: Indicate the related documents (other than the engineering documents identified on Side 1) that will be affected by the change described in Block 13 . Enter the affected document number in Block 20 .

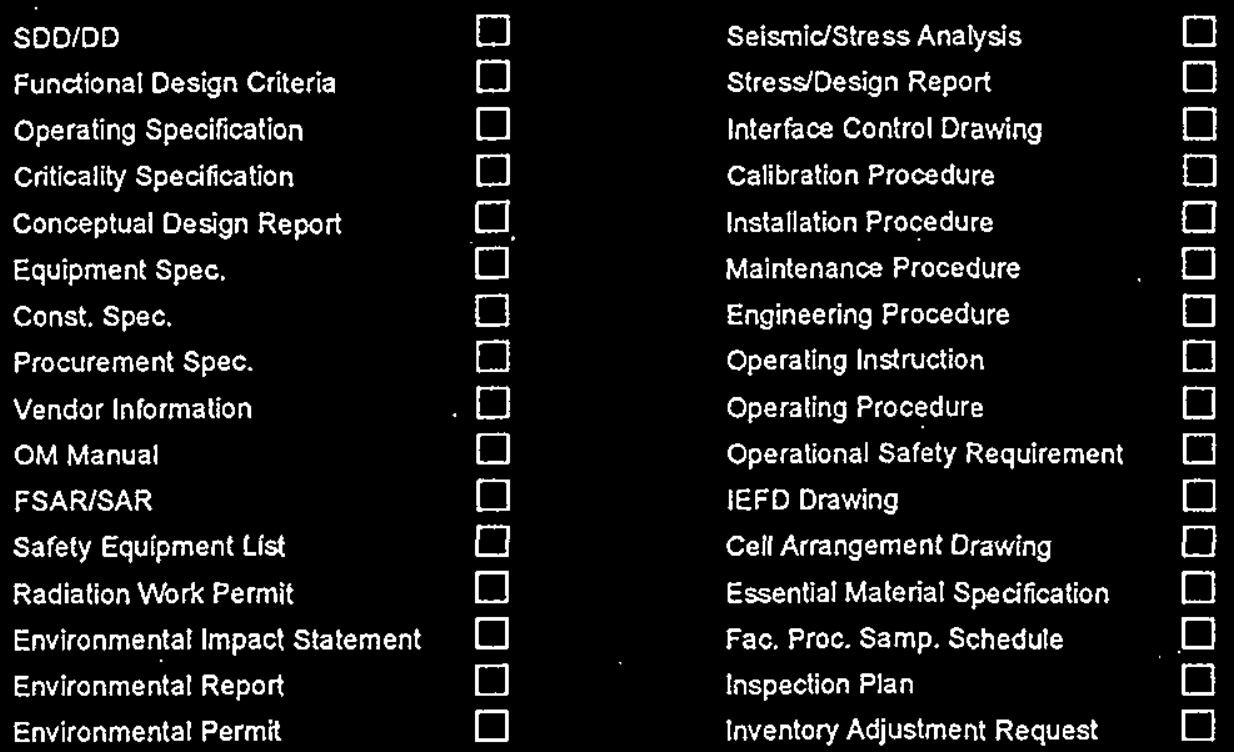

Tank Calibration Manual Health Physics Procedure Spares Multiple Unit Listing Test Procedures/Specification Component index ASME Coded ltem Human Factor Consideration Computer Software Electric Circuit Schedule ICRS Procedure Process Control Manual/Plan Process Flow Chart Purchase Requisition

Tickler File $N / A$

20. Other Affected Documents: (NOTE: Documents listed below will not be revised by this ECN.) Signatures below indicate that the signing organization has been notified of other affected documents listed below.

Design AROT Eng. En $=0 \mathrm{QT}$

QA

Safety
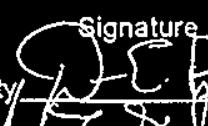

Lthaners

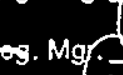<smiles>C1C2C3C4C1C1C2C3C41</smiles> \\ $1 /$}

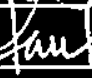
( $M$ Che
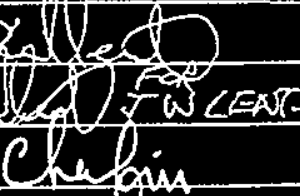

Environ.
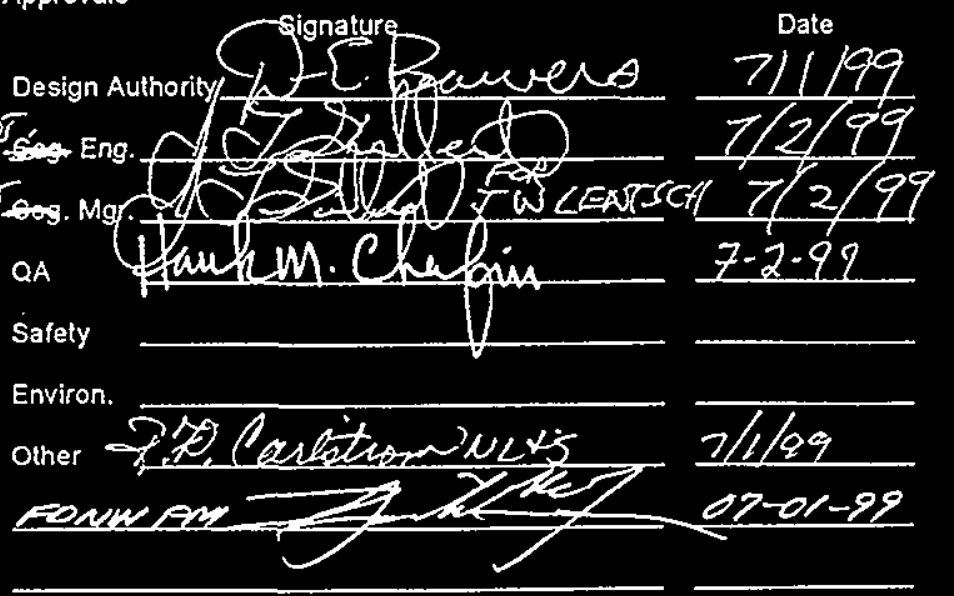

$7 / 100$

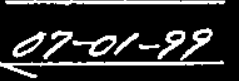

$1 E * 4$

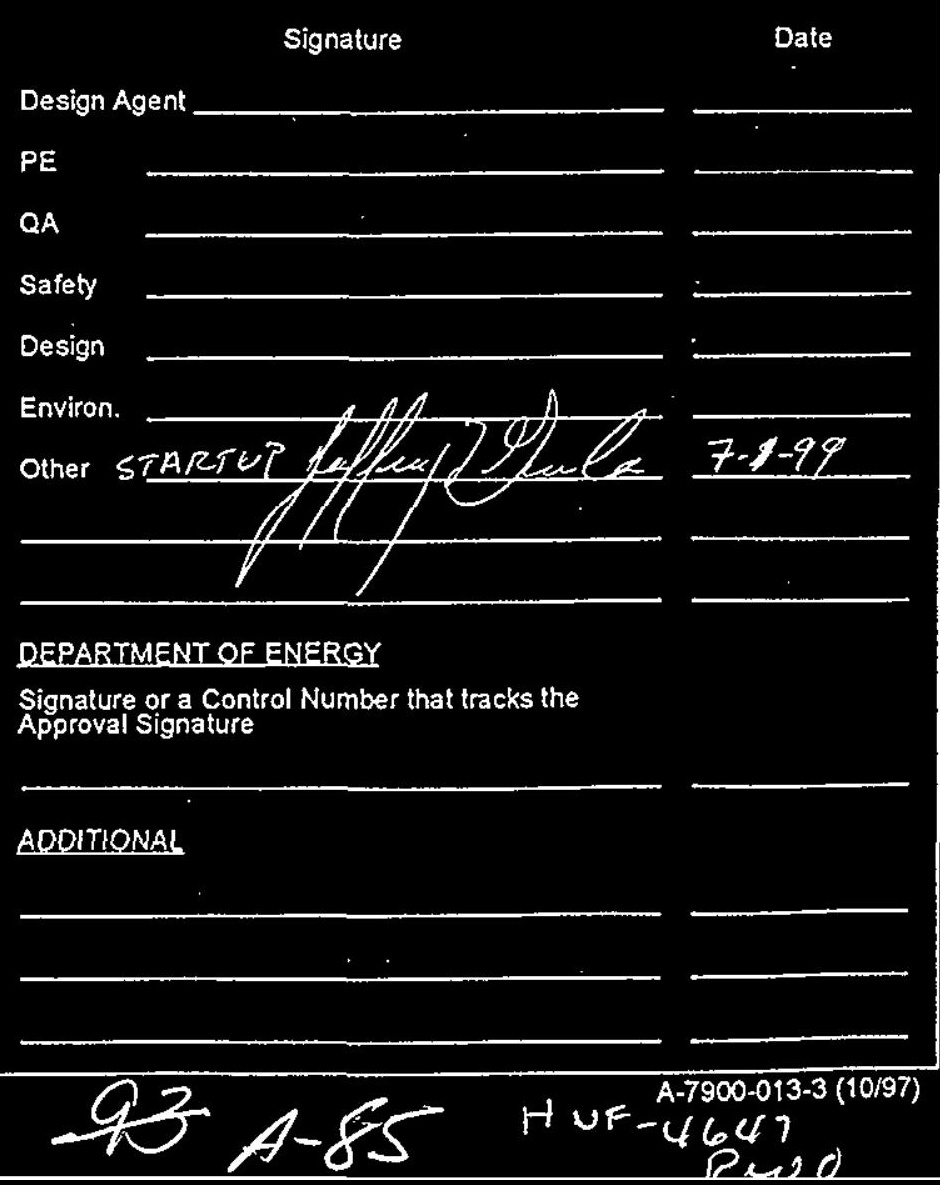




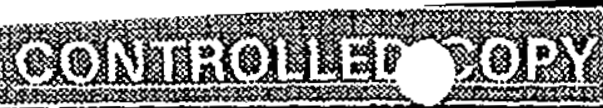

\section{PROCEDURE SIGNATURE SHEET}

S.MI PRICE

JOAN Rluknet

E. F ENLOE

Daud W. Uan Dyke

JEFFREY L. GRUBA

Packe Pfregsiz

WL Dentert

JE Andrens

It CIIDERT

Hank M. Chefin -

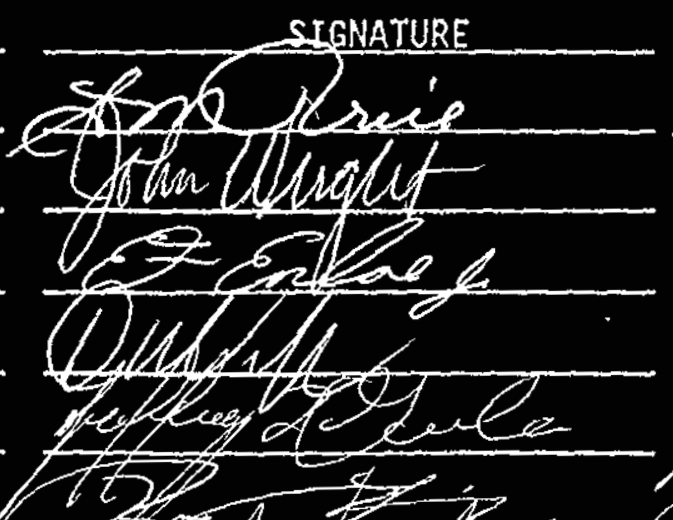

INITIALS

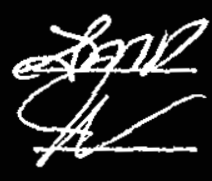

6
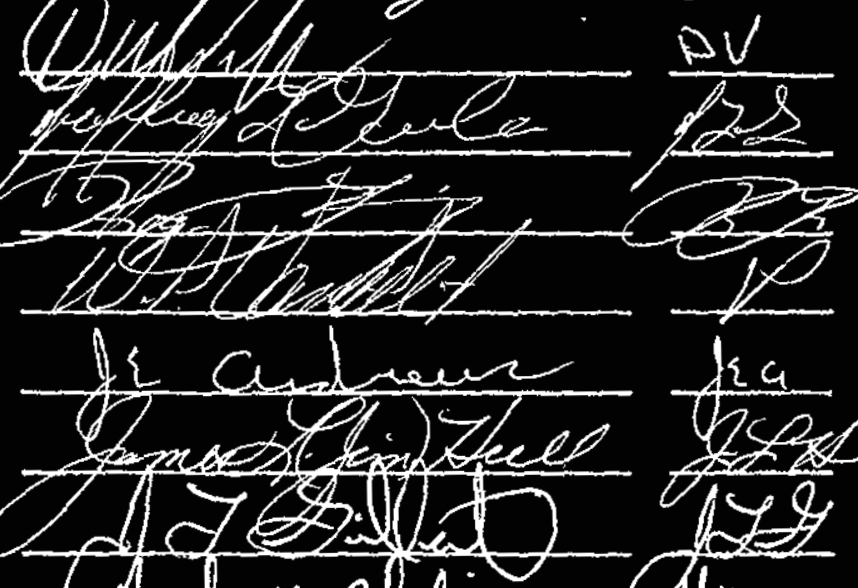

and $m \cdot C h \lim$

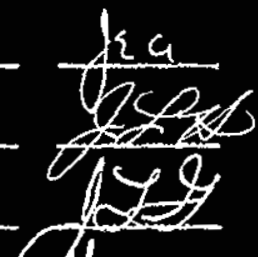

Ine

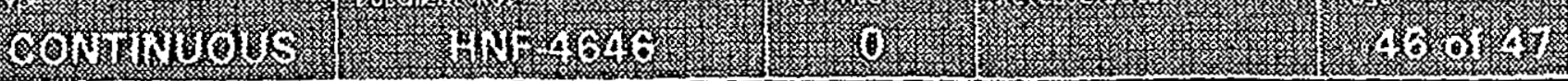

$$
\text { 94 A-glo } \begin{gathered}
\text { HNF-4647 } \\
\text { Rwo }
\end{gathered}
$$


PROCEDURE HISTORY SIGNATURE SHEET 


\section{DISTRIBUTION SHEET}

To

DISTRIBUTION

Project TitleMork Order

Tank Farm Restoration and Safe Operation Project $\mathrm{W}-314$

From
TFRSO W-314 PROJECT

Name

J. S. Hammers

D. I. Syverson

M. A. Lane
Page 1 of 1

Date $8 / 12 / 99$

EDT No. $62700 /$

ECN No.

\begin{tabular}{|c|c|c|c|c|} 
MSIN & $\begin{array}{c}\text { Text } \\
\text { With All } \\
\text { Attach. }\end{array}$ & Text Only & $\begin{array}{c}\text { Attach. } \\
\text { Appendix } \\
\text { Only }\end{array}$ & $\begin{array}{c}\text { EDT/ECN } \\
\text { Only }\end{array}$ \\
\hline R3-25 & $\mathrm{x}$ & & & \\
\hline G3-12 & $\mathrm{x}$ & & & \\
\hline G3-12 & $\mathrm{x}$ & & & \\
\hline
\end{tabular}

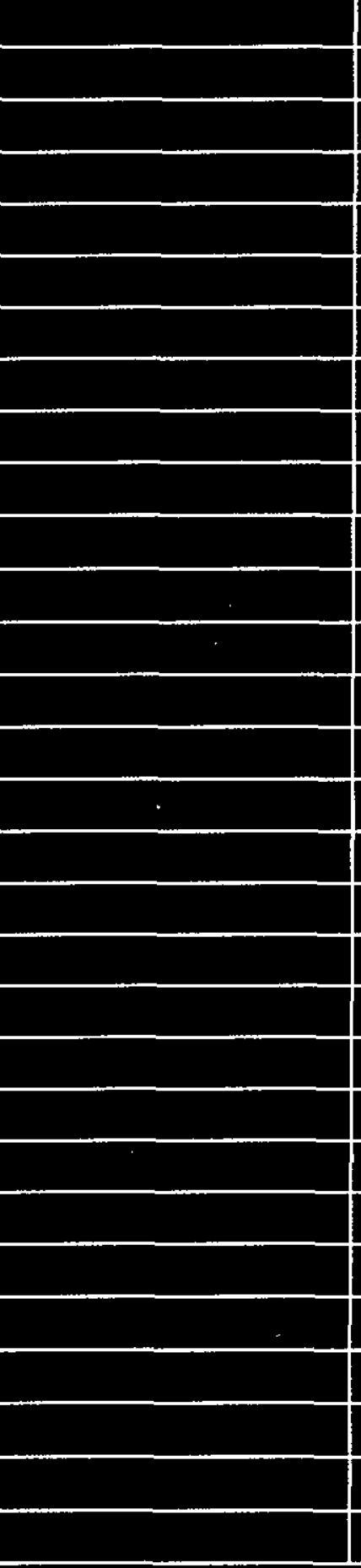

